
年

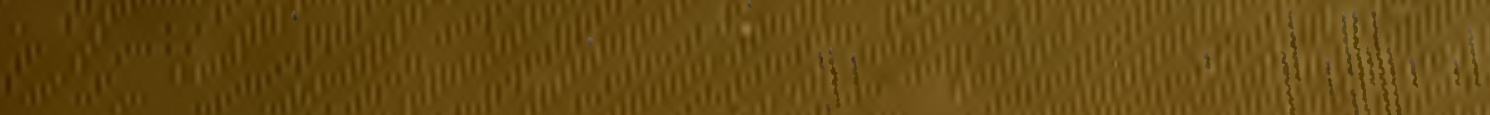

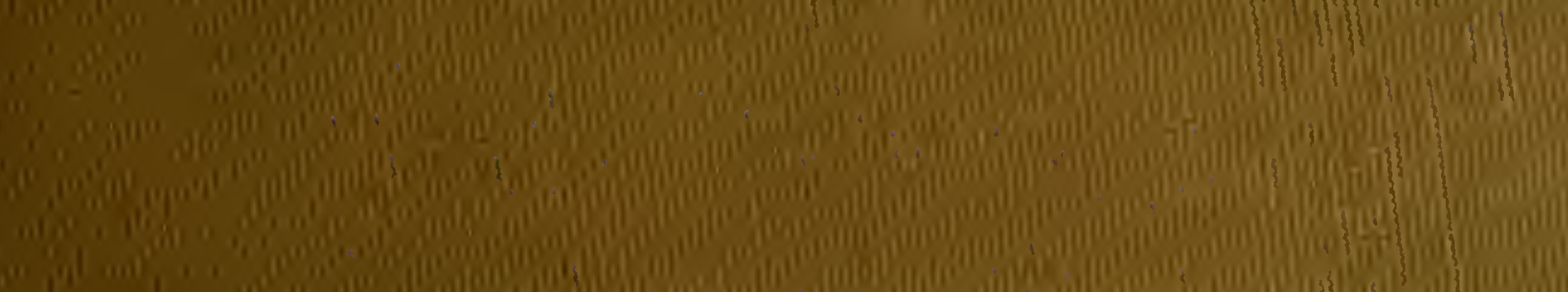

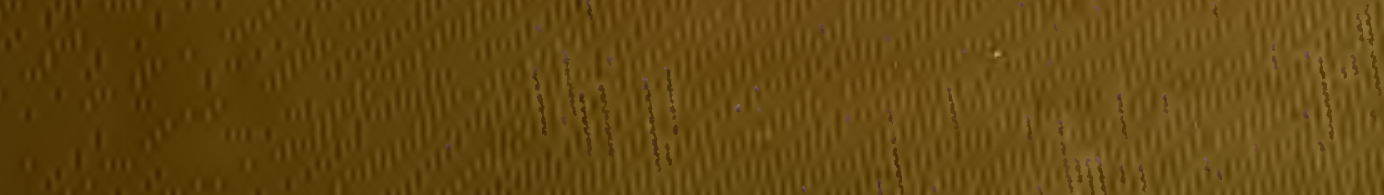

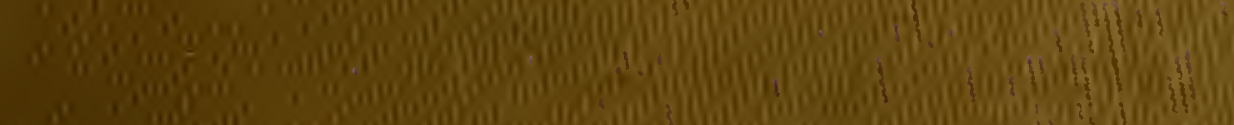

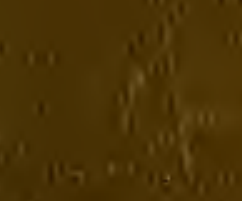

o. 1 \{

ail $10 \%$

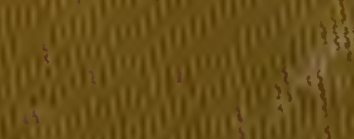

Hit

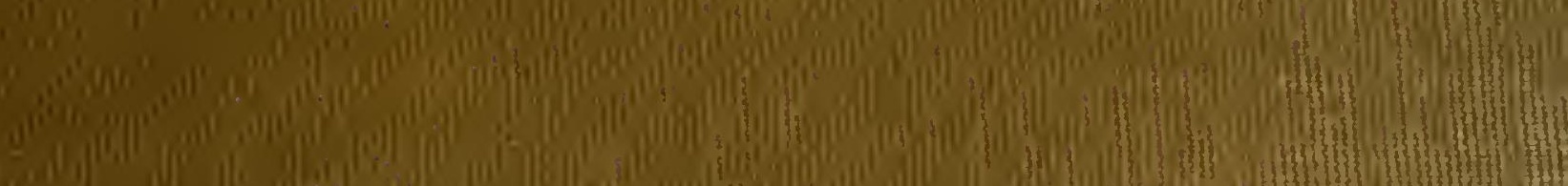
(1)

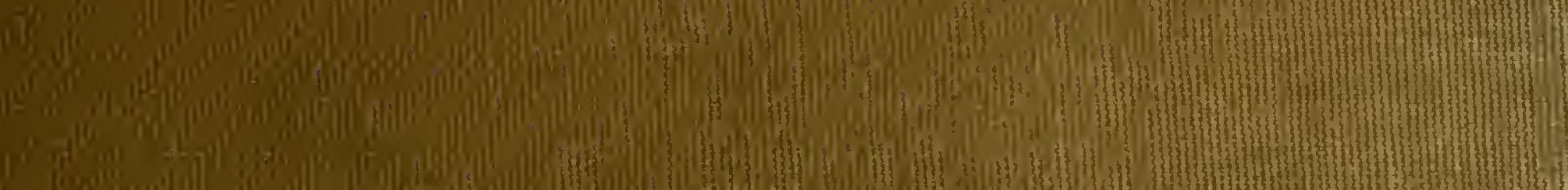




\section{HARVARD UNIVERSITY.}

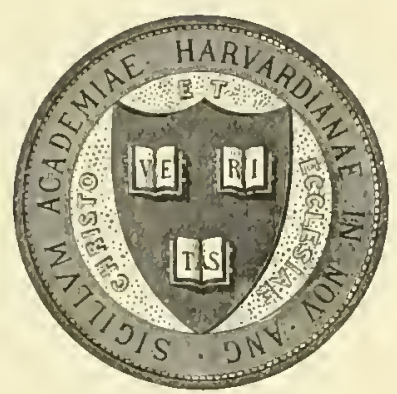

I. I B R A R Y

OF THE

MUSEUM OF COMPARATIVE ZOÖLOGY 44,956

LIBRARY OF

SAMUEL GARMAN

December 19, 1929.

Substituted for copey-entered fax 24, 1917. 
DEC 191929 


nDemotrs of the MDuseum of Comparative zorlogy

A T HARVARD COLLEGE.

Vol. XXX. No. 4.

\title{
THE GALAPAGOS TORTOISES.
}

\author{
BY \\ SAMUEL GARMAN. \\ $=$
}

WITH FORTY-TWO PLATES

CAMIBRIDGE, L. S. A.:

Drinted for tbe nDuseum.

JANUARY, 1917. 


$$
\begin{aligned}
& \text { +3: } 1+1
\end{aligned}
$$

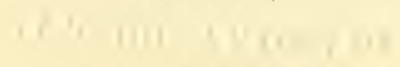

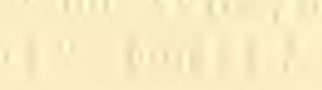




\section{TABLE OF CONTENTS.}

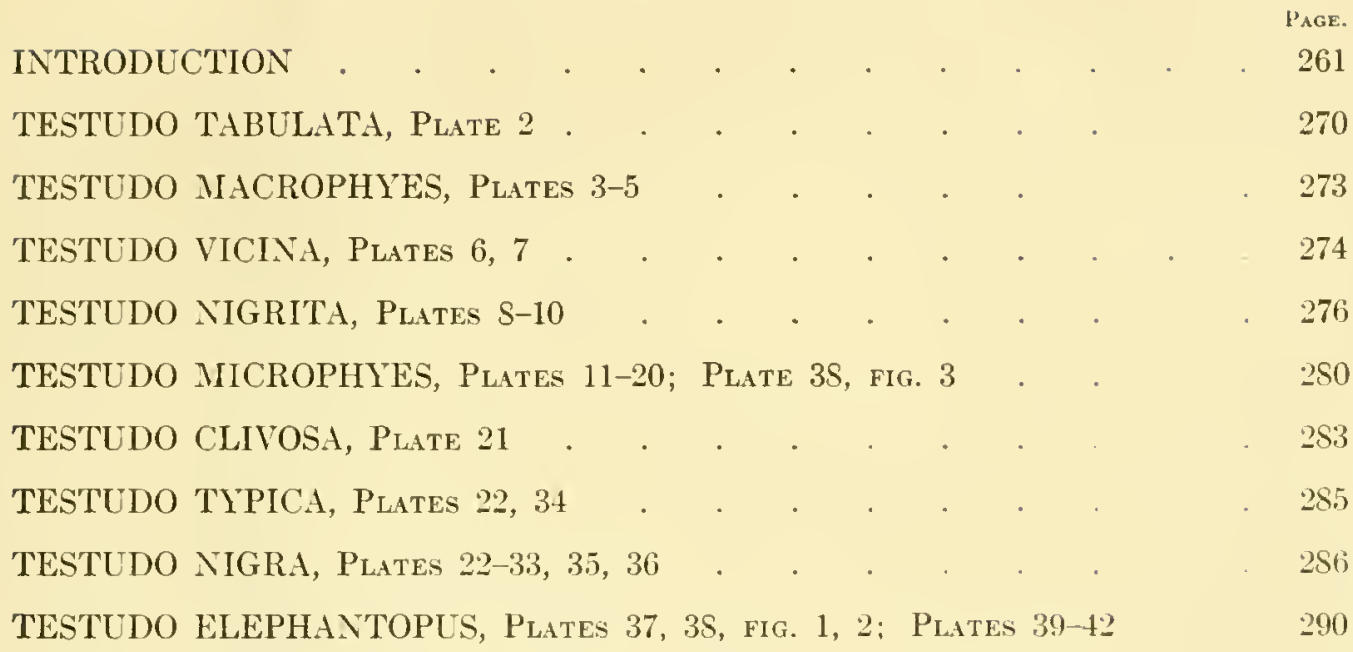

EXPLANATION OF THE PLATES. 
Gnan Zemandy May, 2872 Valparaies may 5 - 1 Caldere his hay Pieco Bay $21-23$ Callas may 24, to gune!. Payta frue 4- 6 charles beland grum 10-12 Altomarle tel. (Tagno eore) gmu 13- 14 games baland gnum is;

givis lelaud" 16

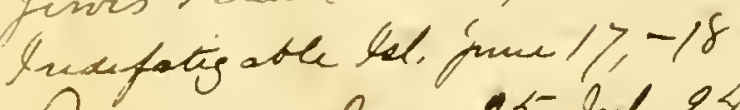
Panana quee 25, fuly 24 Aecentes Aug. $2-1 y$ magdalua Bay Aug. 13,-14 San bigo Aug. 18, - 28 Sam Firancisce Aug. 81.'/z

Hasslex Date and place of totp, 1871-72 


\section{THE GALAPAGOS TOR'TOISES.}

\section{INTRODUCTION.}

A warm interest of the Museum authorities in the Giant land tortoises has led to the acquisition of so many notable specimens, through liberal exchanges and purchases, as to demand a revision of portions of the collection, especially of that portion directly pertaining to the Galapagos Archipelago. This forms the reason for the following article. It is based mainly on partial specimens, $i$. e., carapaces and sternums, but it is thus that these tortoises are most generally known, thus that they are most widely, and most commonly represented in descriptions, figures, and collections. A few attempts have been made at complete characterization of the species by including the anatomical features; these were founded on single specimens, and the individuals of the species are found to differ too much to admit of accurate distinctions unless confirmed by averages secured from repeated dissections, for which much of the material and the labor has yet to be supplied.

The Galapagos Islands form an isolated group in the eastern Pacific on the equator about $6^{\circ}$ west of Ecuador, or in other words, they are situated between $89^{\circ}$ and $92^{\circ}$ of west longitude and between $1^{\circ} 30^{\prime}$ south and $2^{\circ}$ north latitude. The largest of them is about eighty miles long and at its widest is about fifty miles wide; from this the sizes vary to some that are mere points of rock or shoals. They are separated from the mainland by more than four hundred miles of deep sea, a thousand fathoms or more in depth. The wide separation from the continent, their considerable distances from one another, witly great differences in altitudes and consequent variations in elimate and fertility give them exceptional attractions in the eyes of naturalists. Here if anywhere they might hope to find the species of the flora and fauma distinct from those of the world around them and here it might be possible to trace their development and derivation. Questions of origin go back to the advent of the islands themselves; neither in case of lands, plants, nor animals have the questions been answered with any great degrees of satisfaction. Some authorities have decided that the islands are oceanic, that they never were connected with the continent, but were pushed up from the sea-bottom by the numerous volcanoes they contain. 
This accounts for the islands alone. There are two methods of explaining the presence of the organisms: one by origin in place, another by accidental importations. If originating in place similarities in climate and other conditions might be adduced to account for affinities, but accidental importations could hardly be relied on for the development of parallel harmonious series such as are now in place on the Galapagos. The accidents would be heterogeneous, and no reason appears for limiting them in time or numbers.

Theodore Wolf, at one time Geologist of Ecuador, published an account of the Archipelago from actual study, adopted the oceanic theory and placed the appearance of the islands in the Tertiary and later, thereby enhancing the scientific intercst because of the comparatively short period elapsing since the uplifts. He recognized affinities between the insular and the continental organisms, and found the rocks of the Galapagos basaltic and those of the highlands of Ecuador trachyte and andesite.

A most able recent advocate of the continental theory of origin was George Baur, 1891. For months he made collections on a majority of the islands in preparation for a comparative account of the life and conditions. His conclusion was that the Archipelago included the tops of volcanic mountains of a greater area of land at one time part of the continent, later sunken below the sea-level. All the islands were fomerly connected in a single large one which by continued subsidence divided into a number, the highlands that remained above the sea. Each of the latter in a long course of time developed peculiar races, eventually species, in its plants and animals, because the conditions were not identical. As proof especial stress is laid on the harmonious distribution of the organisms. Nearly every island has its own races, and their affinities commonly turn toward the continent. In this the idea of communication and transportation between the jslands is not considered.

Discovery of the Archipelago is said to have been made by Berlanga, 1535. The Giant land tortoises, then found in inmense numbers suggested the name Cralapagos, previously applied in Spain to fresh-water tortoises, a designation which does not appear to have been entered on the maps as a name for the islands till nearly fifty years later. The spaniards paid little attention to the territory. For a couple of centuries it was merely a place of call for a supply of fresh meat. Among the earliest visitors were the buecanecrs, Dampier and Cowley, 168497, who furnished accounts of portions of the group. Cowley published a map on which Spanish names were displaced by English, now perhaps the more widely known. Ecuador, the present owner, clings to the Spanish American 
names and the prospect is that they will ultimately prevail. The Arehipelago was surveyed by Colnett, 1793. The chart, Plate 1, with the positions of the islands, directions of the currents, and the two series of names is sketched from that published under the direction of the secretary of the Nary by the L'nited States Hydrographic Office, 1915. From the dircetions of the currents it will be seen that affinities with South Ameriean organisms would be of the most natural imaginable, if dependence for origins of the flora and the fauna were placed upon the marine drift. The spanish names of the islands with their English equivalents are as follows:-

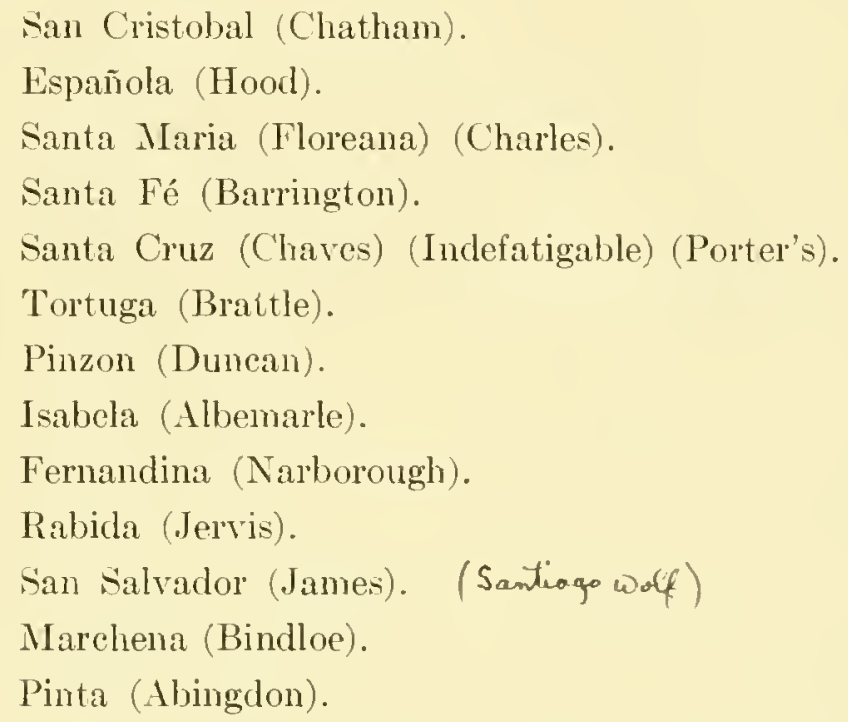

In what ever way the balance of the fauna reached the islands, immediate concern here is with the tortoises, and there is a possibility that they may have been introduced by men. No one would care to assert that they developed from birds or even from marine chelonians. There appears to be a sort of general agreement that they reached the Archipelago as tortoises not very different from what they now are. There is no evidence as yet, in the way of fossils, that they established themselves in the Tertiary or other formations earlier than the most recent. Their affinities are so close to living species on the mainland there is hardly room for doubt their ancestors were the same if indeed a species of the continent was not the direct progenitor brought, possibly, in the times of the Incas or still earlier by the aborigines. Because of the heary and solid structure, one would not risk the suggestion that the Jaboty had drifted across the sea; but there is greater likelihood that island forms may have been drifted from one island to another after finding lodgment in the Irchipelago. Whether it was 
cut off with the islands, from the mainland, or transported by other means it is very likely that the ancestral form is the widely distributed Jaboty, Testudo tabulata (Plate 2) of South America. This is supported by the numerous features possessed by the Galapagos in common with it, and by the comparatively slight divergence. Distribution from island to island was easier in the early days; as the lands sank the distances between the ishands increased. Again there is no proof whatever of inability to swim on the part of the island tortoises. They are not so different from those of the Seychelles which were proved to be good swimmers as long ago as 1801, by Grandpré, Voyage dans l'Inde et au Bengal. If animals like those of the islands of the Indian Ocean were able to swim from shore to shore leagues apart there is positively no reason for denying similar ability to wander to those on the other side of the earth, equally strong and perhaps more buoyant. Porter's testimony, concerning the tortoises thrown overboard by the crews of vessels preparing for action, in which he says "A few days afterward at daylight in the morning we were so fortunate as to find ourselves surrounded by about fifty of them which were picked up and brought on board, as they had been lying in the same place where they had been thrown over, incapable of any exertion in that element except that of stretching out their long necks" is proof only of great buoyancy, a quiet sea and absence of land in sight to direct and stimulate exertions. It certainly is no proof of inability to swim or exert themselves in the water. What would hare happened with favoring winds and currents and shores in view may be readily surmised. Being thrown into the sea is not the only way of going adrift for a creature, fond of soaking in the water and of wallowing in the mud like swine, known to fall from the cliffs and to roll down the declivities.

Transportation by men has certainly played a large part in the history of these creatures. By different resscls they have been carried to the Juan Fernandez, Chile, Peru, the eastern and the western United States, Europe, the Hawainan, Marquesas and Tonga Islands, Australia and China; though there is no evidence at hand of actual colonies being established. There is no very direct assertion of transportation of tortoises from one island to others, except such as were to be used for food, yet in the face of the evidence of mixed breeds or hybricls in collections made in comparatively recent times it is difficult to convince one that such transportations did not occur. The testimony of Wolf, 1879, concerning the cattle lessens the doubt of actual occurrence:- "Das Rind lebt in grossen Heerden auf den Hochplateaus und Bergen von Floreana und Chatham und seit einigen Jahren traf man auch einige Stïcke auf dem 
Gebirge von Süd-Albemarle, ohne das man wüszte wie sie dorthin gekommen sind" (Ein Besuch der Galápagos = Inseln, p. 31). Floreana was the name given by Villamiel to Santa Maria (Charles). Young tortoises of which one might carry a number in his pocket presented no such difficulties as cattle in way of distribution. Cattle like most tortoises are tolerably expert at swimming.

Sailors are fond of pets and a young tortoise or even a giant is an unfailing attraction to them. Undoubtedly they have helped to bring about the puzzling mixtures now gathered in various museums. The islands were frequently visited before the year 1800 , but no attempt was made at colonization. Watkins, a sailor, was said to have been marooned for nearly a year, 1808, on Santa Maria. Villamiel's colony of 1832, on the same island, numbered several hundred people in 1835 and at this time they had continued the destruction of the multitudes of tortoises so effectively that the settlers were drawing supplies from other islands. The Beagle, 1835, got specimens from three of the islands, Santa Maria (Charles), San Cristobal (Chatham) San Salvador (James), mostly young, apparently of a single species or so very young experts were unable to distinguish the species. This colony on Santa Maria was a penal colony. Wolf, 1879, says it soon melted away until finally "der Rest der zuletzt übriggebliebenden Räuberbande rieb sich zum Theil selbst auf, zum Theil entwich er auf den anlegenden Schiffen der Wallfischfänger" (Ein Besuch, p. 4), and for a long time no traces of the colony had existed. Darwin, 1839, p. 457 says of Charles (Santa Maria), "the main article of animal food is derived from the tortoise. Their numbers in this island have of course been greatly reduced, but the people yet reckon on two days' hunting supplying food for the rest of the week." In the seventies Baldisan established a small colony on Santa Maria. He was killed by the colonists about eight years later; after his death this island was deserted. In 1865 Cobos landed a party on San Cristobal (Chatham) to gather Orchilla, a lichen used as a dyestuff; these remained till 1869, when they left the island. Ten years later Cobos returned to San Cristobal with more than a hundred men and founded a colony which appeared prosperous in 1891, and which may yet be in existence. The work of the colony was not limited to the island upon which it settled; it drew supplies from the other islands. The meat hunters, the oil collectors, and the orchilla pickers passed from island to island so frequently that it is not to be expected that any of the islands has its own unmixed race of tortoises, unaffected by mixtures from others. The older specimens, those secured before the exploitation of the islands, are perhaps the least likely to be suspected of being hybridized or mongrelized by 
importations, and a multitude of tortoises already established on an island might not be perceptibly influenced by the advent of a few new additions from elsewhere. The effect of the latter would be infinitesimal, but a species reduced in number of individuals, near extinction, or not yet firmly established, on another island might lose its identity through the advent of one or a few new arrivals, as may have been the case on San Salvador (Janes) where the species no longer agrees with Porter's description, or even on Santa Cruz (Indefatigable) in consequence of the rumored importation by Baur, himself one of the most earnest advocates of the opinion that each of the islands is inhabited by a distinct race. The few individuals that could produce an entirely distinct race in one locality might be unable to produce any effect in another. In specimens of $T$. vicina recently collected there is evidence of considerable mixtures, so also in those of $T$. nigrita and of $T$. clephantopus. The BEAGLE may or may not have secured one species on three islands; four species are located on Isabela (Albemarle). The Hassler, 1872, obtained four species on Santa Maria that may be supposed with some confidence to have originated in four different localities, on three distinct islands.

Comparatively little definite observation by trustworthy observers has been made in regard to either length of life, rapidity of growth, or rates of increase. Waite, 1899, brought together some notes of importance in the Records of the Australian Museum, 3, p. 95-103, pl. 20-22, in regard to a male T. nigrita taken by Porter to the Marquesas, thence to Tonga, thence to Sydney and thence to London where it died in 1898. This follows it nearly a century, without determining its age in 1813. In 1896 the length of the carapace was $4 \mathrm{ft} .2 \frac{1}{2}$ inches, its width $2 \mathrm{ft} .11$ inches and its weight 575 lbs. (p. 98). Rothschild gives the length of this specimen after its death as $48 \frac{1}{2}$ inches. Waite also notices another of this species which weighed 56 lbs. when brought to Sydney in 1853. In 1893 it weighed 368 pounds. In 1896 according to Waite it was an egglaying female, had a length of $3 \mathrm{ft}$., a width of $2 \mathrm{ft} .5$ inches and weighed $320 \frac{1}{2}$ pounds, having lost $47 \frac{1}{2}$ pounds in three years. Quite recently very definite information concerning rate of growth appeared in Science, December 31, 1915, p. 933, in a note by Messrs. Daggett and Heller. The specimen of T. ricina had been secured, by the latter, at Iguana Cove, Isabela, June, 1899, when it weighed 29 pounds and was supposed to be not much over a year old; it doubled its weight annually. Daggett says "At the time of its death [April 18, 1914] it weighed $450 \mathrm{lbs}$. and its carcass measured 41 inches long, 31 wide and 21 high." In about sixteen years the individual had attained the bulk of speci- 
mens commonly said to be 400 years of age. Further observations are needcr concerning rates of increase. Colnet is to be credited with the statement that the nests never contain more than three eggs. Porter says the females without exception were full of eggs of which generally from ten to fourteen were hard, ready for extrusion. Beck says from ten to twenty eggs are ready for extrusion together, while twenty or thirty more were from one half to two thirds the normal size. The number of eggs laid by a single female in a season of course depends on her size and age; at any rate the evidence indicates she might densely populate a given locality, if beyond interference from enemies, in a very few years. Neither rate of growth nor abundance of progeny favors the conclusion that the tortoises have been on the islands from the rery earliest times. Yet in estimating the numbers of the tortoises Baur quoting from Reynolds says that between October 13, 1832 and August 30, 1833, thirty-one whaleships reported at Santa Maria; he adds that if each vessel carried away but 200 it would make 6,000 from this island alone in less than a year. In a later MS. he states there is little doubt that about $10,000,000$ tortoises were taken from the islands since their discovery.

The factors of the greatest importance in the differentiation of species and rarieties are the differences in the altitudes, which in the rarious islands range to 4,000 feet more or less, with the consequent differences in temperature, moisture, dryness, food and feeding habits, soil, etc. The variations in rapidity of growth, sizes attained, increase in numbers and the like are readily traced to one or several of these agents. In some of the most superficial characters their efficiency is quite perceptible; thus for example in the epiderm, the slough, which grows in correspondence with the skin and the bones beneath it.

Sloughing is a process undergone by reptiles in general. It is part of their method of renewing and enlarging the epidermal covering. The new epiderm grows under the old one, the slough, between it and the balance of the skin. In the majority the discarded epidem is thrown off at particular seasons. On some forms it is retained in one way or another and made to serve useful purposes, as protecting the skin or bones, or as claws or spines, and in a few it is so greatly modified as to serve as rattles. There are differences among tortoises in regard to the habit. Most of the marine forms slough early in life and subsequent sloughs are less noticeable. Soaking in the water aids in sloughing, but on the other hand a dry skin appears to be a more effectual preventive of loss and welds the various sloughs together one after another, cementing then firmly so that instead of a single thin horny layer of epiderm, of a single 
season, there may be a thick and strong covering that is increased in thickness by successive growths in its duration. The earliest slough in some marine tortoises is well described in Fry's remarks on Chelonia depressa in, 1913, Records of the Australian Museum, 10, p. 162, "Chelonia depressa then, emerges from the egg with each scute covered by a 'larval shield' which, as the animal grows, becomes an areola almost identical with that found in land tortoises: this is finally shed before the turtle reaches maturity, leaving the smooth scutes described by Garman and figured on Pl. XXI-XXII. As far as I can ascertain these areolae are unique amongst Marine turtles." Günther, 1877, discussing the land tortoises of the Galapagos, says, p. 18, as long as the Tortoises are young, growth, as far as it is externally visible, proceeds along the margins of all the scutes; the sutures get broader, appearing as whitish seams, soft and very sensitive. After some time the young portion of the epidermis becomes horny, and is raised in a line (stria) running along each side of the suture. At a later period this increment takes place only (at least only conspicuously) in certain portions of the carapace." Marine and all land tortoises are hatched with the larval shield on each scute; it forms the areolar space on the scutc which in the land species may or may not be shed, but which appears to be shed in marine forms at an early date. If not shed all the concentric striae remain, unless possibly affected by wear, each successive stria being the index to the amount of surface enlargement or growth, beyond the stria immediately preceding it. If there were no lateral growth, from starvation or disease, the scute, if there were no slough, might thicken by successive accrctions beneath but possibly might not increase the number of concentric striae around its edges. Some specimens from dry localities, have retained the larval shield and have never sloughed; year after year they have increascd by one or more the record of the striae on the scute. Other specimens appear to have kept the sloughs and striae for long periods then suddenly by a slough have lost the entire record of the series at once and from the striate and grooved condition have become smooth and polished, to begin at the edges of each scutc another striated record, see Plate 27. Testudo clivosa, Plate 21, a twenty-five inch specimen may have an entire record. On the youngest spccimens, a year or more of age, of most if not all of the species in the collection, no slough has occurred. The larval shield and all of the striae are in place. Larger specimens of some of the same species show plainly that through a slough the larval shield and the striae have bcen carried away leaving the carapace smooth; still larger ones testify to more or less regularity in sloughing and to consequent 
smoothness: such species are T. nigra, T. microphyes, and T. macrophyes. Testudo vicina, $T$. nigrita, and $T$. elephantopus and its varietics $T$. abingdonii, $T$. becki, and $T$. duncanensis all slough when young and afterward retain the striae as if no sloughing took place.

Evidence that may be adduced in regard to the shortness of time since separation from one another is seen in the affinities of the tortoises; likewise in this connection there is no lack of confirmation for the statement that the species of various islands have been modified by importations from others. The early specimens now in museums, nearly all of then without known localities, are very difficult to place even with the aid of the considerable numbers in recent collections from certain islands. Changes have occurred in the last century that make some of the descriptions quite contradictory. Porter, 1815, in his Joumal describes the tortoises from James Island (San Salvador') as round, plump, and black as ebony, their shells "sometimes remarkably thin and easily broken but more particularly so as they become advanced in age; when, whether owing to the injuries they receive from their repeated falls in ascending and descending the mountain, or from injuries received otherwise, or from the course of nature, their shells become very rough, and peel off in large scales, which renders them very thin and easily broken." Van Denburgh, 1914, in his monograph, p. 321, says "The James Island tortoise is a very large, heavy, thickshelled species which resembles most closely the tortoise of Jervis Island [Rabida] and the T'estudo vicina of southern Albemarle. It is somewhat intermediatc between the saddle-backed and dome-shaped races. The front of the carapace is high, but the middle of the back lises still higher. There is but little narrowing of the front of the carapace." Porter's description was made a century earlier than Van Denburgh's. Porter's description of the tortoises of sinta Maria (Charles) and Española (Hood) applies a little better to $T$. elephantopus Harlan than to T. nigra Dum. \& Bib. now known to be the Charles Island species, of 1835. "The form of the shell of the latter is elongated, turning up forward in the manner of a spanish saddle, of a brown color and consiclerable thickness." How much the differences are is apparent on comparing with the descriptions and plates below. The disagreements may be accounted for by very rapid differentiation, or by modifications or replacements by inportations.

The following descriptions are made for most ready comparison with those in the majority of the literature. Percentages are not given as they do not lend themselves readily to visualization, an absolute necessity in descriptions 
and comparisons; they are too abstract and vary too much with age and sex to be really practicable.

Excepting in the synonymy and the direct references the bibliography is not repeated; it has been worked out by Günther, Baur, and Van Denburgh.

\section{Testudo tabulata Walbaum.}

\section{Plate 2.}

Testudo tabulata WalBaUd, 1782, Chelonographia, p. 122; SchozpfF, 1792, Hist. Test., p. 56, 62, pl. 12, fig. 2, pl. 13, 14; Datdin, 1805, Hist. rept., 2, p. 242; Wied., 1825, Beitr., 1, p. 51; ABBiLd., pl. 一; Beld, 1835, Monogr. Test., pl. -; Duméril et Bibrox, 1835, Erpétol. génér., 2, p. 89; Gray, 1844, Cat. tort., p. 5; 1855, Cat. shield rept., p. 5; Strauch, 1862, Chelon. stud., p. 80; 1865, Verth. schildkr., p. 25; Grar, 1870, Suppl. cat. shield rept., p. 4; Boulenger, 1889, Cat. Chelon., p. 157; Strauch, 1890, Bemerk. schildkr., p. 12; Goeldi, 1904, Chelonios do Brazil, p. 14.

Testudo denticulata Schoе PFF, 1792, Hist. Test., p. 119, pl. 2S, fig. 1.

Testudo tessellata SchNeIDER, 1792, Schr. Berl. naturf. freunde, 10, p. 262.

Chersine tcssellata MERREM, 1820, Tent., p. 31.

Testudo hercules Spix, 1824, Test. Bras., p. 20, pl. 14.

Testudo seulpta SPIX, 1824, Test. Bras., p. 21, pl. 15.

Testudo carbonaria Spix, 1824, Test. Bras., p. 22, pl. 16; Bell, 1835, Monog. Test., pl. 一; Duméril et Bıвron, 1835, Erpétol. génér., 2, p. 99; Stradch, 1862, Chelon. stud., p. 80; 1865, Verth. schildkr., p. 27.

Testudo cagado Spix, 1824, Test. Bras., p. 23, pl. 17.

Chersine tobulata Gravenhonst, 1829, Del. Mus. Vrat. Rept., p. 19.

Testudo boiei WAGLER, 1829, Icon. Amph., pl. 13.

Chelonoides tabulata GraY, 1873, Proc. Zool. soc. London, p. 724, pl. 60, fig. 3.

The conclusion reached in this study of the Galapagos tortoises is that they were derived in comparatively recent time, much later than the Tertiary, from species of the nearer lands of the continent of South America. How their transportation was effected may not be determined at present. In order that the closeness of the relationships with one of the most widely distributed continental species may be made the more evident the following description and illustrations of a specimen of Testudo tabulata from Porto Rico are introduced here. They are taken from a fair representative of the species and will be useful in comparisons. The measurements in inches of the specimen are:-

$\begin{array}{lccccccc}\text { M.C. } Z \text {. } & \begin{array}{c}\text { Direct } \\ \text { length }\end{array} & \text { Width } & \begin{array}{c}\text { Curved } \\ \text { length }\end{array} & \text { Width } & \text { Height } & \begin{array}{c}\text { Sternal } \\ \text { length }\end{array} & \text { Width } \\ 12050 & 22 \frac{1}{2} & 13 \frac{3}{4} & 29 & 25 \frac{1}{4} & 10 \frac{1}{2} & 19 \frac{1}{2} & 11\end{array}$

The shape of the carapace of this species is more elongate than that of T. vicina; it has a circumference of forty-one inches and approaches the subcyclindrical in shape. The sides are steep; they are nearly parallel in an upper view; longitudinally the back makes a long, low arch, which does not rise in the middle as in $T$. nigrita. The front declivity resembles that of the latter. A majority 
of the seutes have little convexity; they are flattened, without prominent areolar spaces. The striae persist near the areolae, except in the older specimens. On the upper half of the fifth vertebral seute there is a rounded prominence or boss and backward from it a steep nearly vertieal deseent. The uppcl and the hinder edges of the third marginal neet in a sharp angle on the presen't individual. The outline of the eighth marginal bends abruptly outward behind the femoral noteh and then continues in a regular eurvature to the caudal. The caudal is large; its lower edge is strongly convex below the contiguous marginals and its surface is prominently convex. Faint scallops are formed by the outward edges of the marginals. A faint keel is between the humeral and the femoral notehes on the fourth to the eighth marginal seutes. The front edge of the fourth vertebral is less than twice as wide as the hinder. The single axillary seute on each side has faint indications of having been formed by the fusion of two; the lower is the smaller and solidly united with the upper. The inguinal scales are single.

On this specimen the sternum extends farther forward than the earapace about one and one fourth inches; it is deeply concare behind the middle and has a rounded prominence along each side of the lower surface. The nuchals are moderate, rounded in front, and have no traces of the lateral angles so noticeable on young specimens. The bones ineluded in the humeral extension in front of the bridge are thick, strong, and curved outward on their outward margins. Compared with the swollen gulars the aral plates are thin; the deep noteh between them is erescent-shaped, concave; the outer angles are produced and blunted.

The seales on the exposed portions of the legs and feet are large, somewhat imbricate and pointed. Each arm has two larger scales in front. Behind the hand there is another, and a short distance from this a smaller one about half as large. Enlarged scales cover the tail, and the exposed portions behind the thighs, similar to those on large specimens of T. microphyes.

Carapace black, with a small spot of yellow on the areola of the seeond rertebral seute. Lower surfaces and head yellow mottled with brown or black. Skin between seales brown on neek and legs.

Of this speeies, in Brazil, Goeldi, 1904, says "Testudo tabulata, o nosso jaboty, é animal imponente, euja casca dorsal por si só póde attingir de 55 até $70 \mathrm{em}$. de eompriniento." The largest at hand is that deseribed above, $57.15 \mathrm{~cm}$.

Among the small specimens, from numerous loealities between Dominica, Trinidad, Surinam, and southern Brazil, there is the same dissimilarity in the 
young as compared with the old of this species, or with the Galapagos tortoises of whatever ages. For example, the majority of the young of $T$. tabulata have two axillary scales on each side. They are not as seen in T. argentina Sclater, T. chilensis Gray, shown by Siebenrock, 1912, fig. 1, where the lower is the larger. The lower is much the smaller; in cases it is absent, in others, it evidently has fused with the upper, thus bringing about the condition obtaining in the Porto Rican specimen, normal in the Galapagos. There is evidence that the single axillary is not excessively rare: it was figured by Schoepff, 1792, Pl. 13-14, as T. tabulata Walb., by Spix, 1824, under the synonym T. sculpta, Pl. 15, and by Bell, 1835, Mon. Testud., Pl. - Sowerby and Lear, 1872, Pl. 14, uncler T. carbonaria Spix, Pl. 16, another synonym. The young of $T$. tabulata vary greatly in color, from yellow to black. On the back, whether light or dark the areolae are commonly yellow to orange, the color being more limited on the black individuals. On the majority the lower surfaces are yellowish, as to a considerable extent on the Galapagos. Specimens of less than six inches have marginal denticles on a thick swollen sternum, more or less produced, notched, and angled in front, etc., and they differ in some of the same features from the large or the aged of the species and from the Galapagos of whatever size, age, or species. The typical forms described as species of the latter have most often been chosen from the adult or the aged and these have provided the distinguishing characters from those induced by age. Among the old the greater difference exists and from them the more one approaches the newly hatched the more alike the specimens appcar. This is what should be expected in cases of close genetic relationship. Comparing the tortoise of northern South America with those of the Galapagos it is found that the nearer approaches from the one to the other's are the farther from the egg and mainly made by T. tabulata. Yet it is very doubtful if such close affinities would have obtained without the aid of a common ancestor. The results of all the comparisons made in this study tend to the conclusion that the origin of the Galapagos tortoises is directly connected with the species $T$. tabulata of northern South America. 
TEstudo MackopHYes, sp. nov.

Plates 3-6.

Testudo microphyes GüNTHER, 1877, Gigantic laud-tortoises, p. 78, pl. 32-36, 38, 45, fig. A-C (part); Beck, 1903, 7th Ann. rept. N. Y. zoöl. soc., p. 170; Siebeanock, 1909, Zool. jahrb. Suppl., 10. p. 534; Van Denburgh, 1014, Proe. Cal. acad. sci., ser. 4, 2, p. 329, pl. 70-83 (part); Rothschild, 1915, Nov. zool., 22, p. 406, 409 (part),

Testudo macrophyes is the name here applied to a tortoise inhabiting the section of Santa Isabela Island (Abemarle) near Tagus Cove. The tortoise was first made known by Günther, in 1877, who described and figured it from a number of the Cookson specimens but he did not recognize the species as distinct. He made it identical with that he had characterized in 1875 under the name $T$. microphyes from a specimen of unknown origin, said at the time to be "a fully adult male" representing the "smallest of the Galapagos Tortoises" and supposed to have come from Española Island (Hood's).

Testudo macrophyes is one of the largest species. Compared with that of T. microphyes, Plate 11, the carapace appears more elongate, narrower across the humeral region, broader across the femoral plates, and somewhat higher in the arches across the middle of the back, over the third and the fourth vertebrals. Viewed from above the outlines in some degree resemble those of $T$. ephippium. The convergence toward the front and the incline of the flanks are greater than on T. microphyes and consequently the opening in front between the carapace and the plastron approaches an angular in the nuchal section. The notch at the eighth marginal on each side appears more decided because of a slightly greater spread of the marginals over the femoral arches and farther back. The striac of growth are present on the younger; on the old they are more effaced. The straight width is about three fourths of the straight length; the curved width is little greater than the curved length. The differences in the sternum are even more patent. The humeral extension from the front of the bridge is narrowed forward; the gular plates are reduced, somewhat pointed, and are partly separated by a notch, Plate 5, fig. 3. The femoral extension from the bridge backward is narrowed toward the anal plates, which appear small, though larger than the gulars, and are rounded to meet in front of the shallow notch.

Plate 3 shows the outlines of the carapace of the half grown specimen figured in Günther's, 1877, Plate 38, Plate 5 those of the 27 inch female on his 
Plates 35, 36, and on Plate 4 are those of the thirty-three and a half inch male drawn on his Plate 34 and fig. A of Plate 35. The following measurements, in inches, were given of the Cookson specimens, all supposed to be from Tagus Cove.

$\begin{array}{cccccc}\text { Length } & \text { Width } & \begin{array}{c}\text { Curved } \\ \text { length }\end{array} & \begin{array}{c}\text { Curved } \\ \text { width }\end{array} & \begin{array}{c}\text { Sternal } \\ \text { length }\end{array} & \begin{array}{c}\text { Sternal } \\ \text { width }\end{array} \\ 25 & 19 \frac{1}{2} & 32 \frac{1}{2} & 34 \frac{1}{2} & 20 \frac{1}{2} & 16 \frac{1}{2} \\ 33 \frac{1}{2} & 24 \frac{1}{2} & 41 & 42 & 24 \frac{1}{2} & 23 \\ 33 \frac{1}{2} & 25 & 44 & 46 & 27 \frac{1}{2} & 25 \\ 27 & 22 & 35 & 38 & 21 \frac{1}{2} & 20\end{array}$

\section{Testudo vicina Günther.}

Plates 6, 7.

Testudo vicina Günther, 1875, Philos. trans. Royal soc. London, 165, p. 277, pl. 35 A, 40, fig. B, pl. 41, fig. A, C, pl. 45, fig, C, C', D; 1877, Gigantic land-tortoises, p. 73, pl. 31, 46, fig. B, pl. 47, fig. A, C, pl. 54, fig. C, C', D; Bodlenger, 1889, Cat. Chelon., p. 170; Rothschild, 1902, Nov. zool., 9, p. 445; Heller, 1903, Proc. Wash. acad. sci., 5, p. 54; BecK, 1903, 7th Ann. rept. N. Y. zoöl. soc., p. 164; Siebenrock, 1909, Zool. jahrb. Suppl., 10, p. 354; Van Denbergh, 1914, Proe. Cal. aead. sci., ser. 4, 2, p. 344, pl. 93-110; Rothschild, 1915, Nov. zool., 22, p. 406.

Testudo elephantopus Baur, 1859, Amer. nat., 23, p. 1044; Lucas, 1891, Smithsonian rept., pl. 104, fig. -; Gadow, 1901, Cambridge nat. hist., 8, p. 375.

Testudo nigrita Cope, 1889, Proc. U. S. N. M., p. 147; Lucas, 1891, Smithsonian rept., pl. 104, fig. - .

In the lot of young tortoises purehased by Prof. Louis Agassiz on Santa Maria Island (Charles) in 1871 there is a fourteen inch specimen of Testudo vicina. How it came to be on that island is not known. From the young it is very evident that this species is most closely allied to $T$. nigrita, Plate 10. Testudo vicina differs from the latter in being longer, narrower, and higher, and there are other differences of which the measurements give no hint. The length orer the curvature at this stage of growth about equals the width over the curvature in each species. The carapace of $T$. vicina is the more flattened, it is more depressed, that is, it has less of the dome shape on the middle of the back. The arches between the areolae of opposed costal plates are lower and broader. The curves from the nuchal notch to the areola of the fourth vertebral scalc are broader and the descent from that point to the lower edge of the caudal seute is less steep. In the sternum, the two species are similar in the gular and the anal scales. The areolar spaces appear to be smaller on the back of $T$. vicina, but the striae are equally distinet. A photograph of the specimen is shown in Plate 6. The outlines of the type, as drawn by Ford for Ginther, 
1875. Plate $35 \mathrm{~A}$, from a thirty-three inch specimen, are included in Plate 7. Specimens at hand are more curred from the middle of the fourth vertebral scale to the anterior marginals than in this drawing. In the fourth vertebral and backward the curve is sharp, but the marginals are less dechyous, which is also true of the forward marginals. On both front and back the marginals are somewhat reverted, concave on their upper surfaces, in the older specimens. A number of the specimens in the M. C. Z. were secured by Webster near Iguana Cove in the southern part of Santa Isabela (Albemarle); these are compared with the figures of those secured by Van Denburgh in the same locality. The declivity from the middle of the fourth vertebral baskward is usually greater than that forward from the second. The caudal plate is directed downward, and slightly forward at the lower edge. A large shallow notch partly separates the marginals of the foremost pair. The indentation at the fourth, and that at the eighth marginal, on each side are shallow, as also the grooves, compressions, cxtending from them. Except perhaps on specimens of greatel age, the concentric striae are present. The arcolar spaces vary in convexity; in cases they are prominent. The carapace is broader posteriorly; it appears subtruncate, the caudal scale being indented between the marginals at each side of it. In front the margin is the more rounded, subacuminate. Above the humeral and the femoral arches the marginals form scallops.

The sternum of the type is longer than broad; the humeral extension, in front of the bridge, is broad at the end and is somewhat concave on its lateral margins in the large specimens. The femoral extremity is shorter, broader, and is convex on the lateral margins of the abdominal plates. In both young and old the gulars thicken upward; on the aged they have a comparatively small amount of the downward swelling. The anal scutes are broader than the gulars and have an angular notch between them; they thicken and curve downward with age. The sternal concavity is dcepest below the hinder portions of the abdominal scales; it is deeper on the old males.

In recent collections of specimens of this species there are appearances of considerable mixtures by transportation from one island to another. The earlier captures appear more distinct than some of the later ones. Undoubtedly the oil collectors, the orchilla pickers, the meat hunters and others were quite ready to contribute to a distribution that has left traces in various directions, and lattcrly the young specimens from different islands have been on sale within reach of collcetors at particular localities. 


\begin{tabular}{|c|c|c|c|c|c|}
\hline \multicolumn{5}{|c|}{$\begin{array}{l}\text { Measurements. } \\
\text { (In inches). }\end{array}$} & \multirow[b]{2}{*}{ Height } \\
\hline M. C. Z. & $\begin{array}{l}\text { Direct } \\
\text { length }\end{array}$ & $\begin{array}{l}\text { Direct } \\
\text { width }\end{array}$ & $\begin{array}{l}\text { Curved } \\
\text { length }\end{array}$ & $\begin{array}{c}\text { Curved } \\
\text { width }\end{array}$ & \\
\hline 4482 & $14 \frac{1}{4}$ & $10 \frac{3}{4}$ & $1 S_{\frac{1}{2}}$ & $1 S \frac{1}{2}$ & 7 \\
\hline 11076 & 27 & 21 & $34 \frac{1}{2}$ & $35 \frac{1}{2}$ & $14 \frac{1}{4}$ \\
\hline $11077^{9} 8$ & 30 & 24 & 36 & $40 \frac{1}{2}$ & $15 \frac{7}{8}$ suat mial .rever ot 2 \\
\hline $1107 \mathrm{~S}$ & $28 \frac{3}{4}$ & $22 \frac{3}{8}$ & $34 \frac{1}{2}$ & 37 & $14 \frac{5}{8}$ \\
\hline 11087 & 39 & $28 \frac{1}{2}$ & $47 \frac{1}{4}$ & 50 & $18 \frac{1}{4}$ \\
\hline
\end{tabular}

Testudo nigrita Duméril et Bibron.

Plates 8-10.

The Great Gallapago-Tortoise M1тchill, 1815, Med. repos., ser. 2, 2, p. 309, 402.

Testudo nigrita Duméril etr Brbron, 1835, Erpétol. génér., 2, p. 80; Stradch, 1865, Verth. schildkr., p. 25; Güxther, 1875, Philos. trans. Roy. soc. London, 165, p. 267, pl. 33, fig. B, pl. 35, fig. C, pl. 37, fig. B, pl. 38, fig. D, pl. 39, fig. D; 1877, Gigantic land-tortoises, p. 69, pl. 30, fig. B, pl. 31b, fig. C, pl. 42-44, figs. D; Bodlenger, 1889, Cat. Chelon., p. 169; Stradcr, 1890, Bemerk. schildkr., p. 52; Waite, 1899, Records Austr. mus., 3, p. 95, pl. 20-22; Heller, 1903, Proc. Wash. acad. sci., 5, p. 50; Siebenrock, 1909, Zool. jahrb. Suppl., 10, p. 531; Rothschild, 1915, Nov. zool., 22, p. 407 .

Testudo indica Gray, 1831, Syn. rept., p. 9 (part); 1844, Cat. tort., p. 5; 1855, Cat. shield rept., p.6, part; 1870, Suppl. cat. shield rept., p. 5; SOWERBY \& LEAr, 1872, Tort., pl. 6.

Testudo planiceps Grar, 1855, Cat. shield rept., p. 6, pl. 34; 1870, Suppl. cat. shield rept., p. 5.

Testudo clephantina \$ттапсн, 1862, Chelon. stud., p. S3.

Testudo elephantopus Grat, 1870, Proc. Zool. soc. London, p. 708, pl. 41 (part); 1872, Appendix cat. slield rept., p. 3.

Testudo wallacci VAn Denbtrgh, 1914, Proc. Cal. acad. sci., ser. 4, 2, p. 351, pl. 111, 112.

Testudo porteri Rothschild, 1903, Nov. zool., 10, p. 119; SiebenRock, 1909, Zool. jahrb. Suppl., 10, p. 532; Van Denburgh, 1914, Proc. Cal. acad. sci., ser. 4, 2, p. 354, pl. 113-121.

Testudo daruini Van Denborgh, 1907, Proc. Cal. acad. sci., ser. 4, 1, p. 4; Siebenrock, 1909, Zool. jahrb. Suppl., 10, p. 533; TAN Denburgh, 1914, Proc. Cal. acad. sci., ser. 4, 2, p. 319, pl. 56-63; Rothschild, 1915, Nov. zool., 22, p. 405, pl. 36.

Testudo sp. Vai Denburgh, 1914, Proc. Cal. acad. sci., ser. 4, 2, p. 362, pl. 122.

A young specimen of this species, measuring eleven and one half inches in direct length, Plate 10, does not differ greatly in its shapes from the smaller of the types originally described, which measured twenty-two inches, and of which the outlines are sketched on Plate 9 from the plate by Günther, Trans. Zool. Soc. London, 1875, 170, pl. 35, fig. C. The carapace is a short broad oval, rounded in front and over the femora, and subtruncate across the caudal section. Its height is about half of the length; the back is broadly arched. At the nuchal notch the height is about half of that in the middle of the body. The strongest vertebral declivities occur from the areolar space of the first vertebral scale forward and from that of the fourth vertebral backward. The flanks are nearly straight and bear a low keel below the areolar spaces of the 
costal scales from the fourth to the eighth marginals, continuous with the edges of the carapace in front and behind. This licel is not retained on old specimens to such an cxtent as on $T$. clivosa, Plate 21 . There is a weak notch on each side at the fourth marginal and another at the eighth; the groores from these notches extending toward the nuchal notch and toward the caudal scale are shallow but distinct. In front of the humeral notches, and behind the femoral, the marginals form scallops. Anteriorly the marginals hare a slight incline downward. All of the scales are strongly marked by striae. The amount of prominence in the areolar spaces varies; on specimens of a length of two feet or thereabout the areolars are decidedly prominent on the first and on the fourth and the fifth rertebrals. The descent from the fifth is quite steep. The striae persist on some; on other species they are nearly or completely lost, Plate 36 ( $T$. nigra). The bones are light. On the sternum the concavity is absent or shallow on the young, of moderate depth on specimens more than half grown. The gular scutes are narrow and swollen above the ends which are slightly turned downward below the edge at each side of a shallow notch. The anal scutes are longer than wide and the pair are separated behind by a moderate notch; the angle on a scute is thin, sharp, and curled upward somewhat. The caudal notch persists on large specimens. Plate 8 contains the outlines of the larger of Bibron's types, a forty-one inch specimen, taken from Günther's figure $\mathrm{B}$ of his Plate 33, apparently a $q$. Males of more than thirty inches have served as types for $T$. wallacei, $T$. porteri, and $T$. darwini. This sex is commonly the more elongate and the flanks are less full and rounded. Occasionally the curved width is less than the curved length, as in case of the type of $T$. darwini but in most cases the curved length and the curved width are nearly equal, while the direct width is two thinds to three fourths or more of the direct length. Specimens identified with this species have been collected on Santa Maria (Charles), Santa Cruz (Indefatigable), Rabida (Jervis), San Salvador (James), and on Middle and on South Isabela (Albemarle).

The color is a uniform dark brown or black, commonly without yellow markings on the lower surfaces.

In all likelihood a note by Mitchill, 1815, was the first mention of this species. The measurements he gives are impossible when applied to any known tortoise of the Galapagos, but they make their nearest approach to T. nigrita. Since the article Description of the great Gallapago-Tortorsef From Dr. Mitchill's Lectures on Natural History, contains interesting matter, and has been ignored heretofore, it is reprinted from the Medical Repository, 2, p. 309 and 404. 
"Ahout the mildle of July, IS14, the ship Essex Junior, Lientenant Downes, of the U. S. Navy, arrived in New York. He had been on a cruise, by order of government, along the coast of Brazil, and round Terra del Fuego, and oft the land of Chili and Peru. in quest of British traders and whale--men. He served under Commodore David Porter, of the frigate Essex, a vessel of war which had almost broken up the enemy's navigation and commerce, in the traet of ocean lying between Cape Horn and the Gallapagos Islands.

After visiting Valparaiso and Lima, in Mareh, 1S13, Capt. Porter proeeeded to the neighborhood of this group, and cruised there between April and Oetober, for English vessels, where he captured twelve, which were chiefy occupied in the chase of the spermaceti whale. He describes the Gallapagos Islands as "being perhaps the most barren and desolate of any known," and so utterly kestitute of fresh water, that he was obliged to touch on the coast of Ameriea, during the time, to procure a supply of that necessary article. They are ehiefly voleanic piles, and the water that condenses on their summits is alssorbed by tufa, slag, and ashes, before it can reach the sea.

From the Gallapagos the erew took a number of the native tortoises for food. These ereatures are very large, and frequent there. They inhabit the land, and seldom or never enter the water from choice. Two of them were brought alive to New York. They bore the voyage of between two and three months without taking any food. They have been carefully examined, and described. Both were females. The larger had the following eharacters.

The colour of the buckler and skin was a deep and uniform black.

The head was rather small in proportion to the body, and at pleasure could be drawn out of sight, and concealed behind the fore legs, approximaterl for its protection.

The back was very conrex. The sides prominent and eapacious; but the gibbosity was without knobs, asperities, or proeesses; and merely marked by dividing lines, among the pannels. There were five of these pannels along the back, four on eaclo side, and twentythree in the circumference, making thirty-six in the whole.

The length, measured over the elevation of the buckler, lectween head and tail, was about two feet and a half. The distance from side to side over the back was almost as great, or nearly twenty-ninc inehes. The height, as the animal rested on the belly or sternum, was about two feet.

The weight, when she arrived, poor, lean and famisherd was righty pounds.

The fore part of the legs was covered with a thick and hard skin, that by deep indentations resembled the seales of an alligator's hicle. Each of her fore feet had five claws; of the hinder, four, and the balls of her feet were prominent and puffed, als if for walking over the ground, and not for creeping, or crawling. Such is the length of her legs, that her ercet posture adds about a foot to her stature.

This individual, weak and exhansted as it was, could move with the weight of a man on its back.

The fore part of the crown of the head was rougl, like the legs.

It arrives in its native region, to the magnitude of three hundred pounds, and even more. When full grown and strong, it can travel away with the weight of three or four men. It is very prone to accumulate fat. In cooking the flesh there is no need of employing butter.

It can live, as is said, a year, without food or drink.

The sailors travelled two miles and more inland upon the Gallapagos Islands in seareh of these tortoises, or turpins as they called them. When they eatch the animals, they carry them in their arms, or on their shomlders, to the hoat. There were more than two hundred on board the Eissex. The English whahing vessels that were captured, mostly harl some of them. Navigators prize them highly for fool, and esteem then as savoury and wholesome. One of the men told me he had scen the same sort of tortoises on the Isles Tristan d'Aeunha 
and Bourbon. Like the camel, the turpins have a stomadh or reservoir in which they prescrve water to the amount of several quarts for a long time. Voyagers sometimes kill them for the purpose of procuring this water to drink, which they pronounce to be cool and sweet. Commorlore Porter told me he had repeatedly tasted it, and could hear witness how good and potable it was. The water the stomach contains is sufficient for cooking the flesh. 'The Gallapagos are stated to abound in volcanoes, and subterranean fires. 'They are rocky, peaked and forbidding. There are few springs or brooks of water. With great difficulty and excrtion the Essex collected about half a dozen casks; and then sailed for the continent to obtain a further supply. There are no settled or stationary human inhabitants.

The seas abound in excellent fish and grcen turtle. Cocoa-nuts may be found in some places on shore. And the Guanos lizard may be catched for eating. But it must be remembered that this is the Sea-Guanos, a species of lacerta, entircly different from that of the West-Indics. The Sea-Guanos of the Gallapagos, swim and feed in the ocean, and go ashore to rest and breed."

\section{The following occurs on p. 404 of the same volume:}

"On the 13th of February, 1815, I cxamined the borly of the female Gallapagos tortoise.

I found the alimentary canal to be exceedingly large and capacious. The whole length of this tube, from the throat to the anus, was about thirteen feet. Of this the gullet and stomach were twenty inches; the small guts five feet, and the large ones six feet and a half. The cacum hat no appendages; the colon had faint and weak museular bands; and the rectum communicated with the uterus and bladder a few inches before the posterior outlet. They are all mited with one common cloaca.

The bladder contained a considerable quantity of urine. It was remarkably large, and capable of holding four quarts of water, as we found by experiment. The creature, when alive, voided naturally great quantities of urine.

The animal is said to hold within it, when in health, a plenty of potalle water. I found none in this individual; though the stomach, colon, and bladder could each have contained a large supply. The reason probably was, that the creature had been for a long time under artificial restraint, and had been crammed to death, through kindness, by Indian meal (neal of maize). The uterus contained two eggs almost ready for exclusion, the weight of one alone was six ounces. These had beautiful calcarions shells, that were rough, white, round, and about the size of a one pound shot. It was divided into two parts, and the ova were very numerous, and of different sizes. Near the junction of the two cornua uteri with the strait intestine, were the two kidneys of a triangular figure, and of a convoluted structure. Their extreme length was four inches, and the breadth of the widest part two and a half.

The trachea clivided into two branches, one of which entered each hung. The cells of this organ were open, large, and distinct, as nsual in these amphibious creaturcs.

There were two large muscles parallel with the back, for retracting the neck. One of them arose from each side of the cervical vertebrae; they were of extraordinary length, and were inserted in the shell towards the rump. The outcr coat of the shell looked as if it was sufficiently beautiful for manufacture.

The heart consisted of two auricles and one ventricle; the auricles were separated by a septum. The pulmonary veins emptied into one, and the vena cava into the other. There was but a single ventricle; and two fleshy valves, in shape somewhat like the epiglottis, opposed the return of the blood from the ventricle into the auricles.

From the ventricle proceeded three arteries; two of which soon divided into two branches each, making five in the whole, soon after leaving the heart. The heart was oblong and kidney shaped. These arteries had appropriate valves at thcir origin." 


\section{Measurements.}

(In inches).

\begin{tabular}{|c|c|c|c|c|c|c|}
\hline & $\begin{array}{c}\text { Straight } \\
\text { length }\end{array}$ & $\begin{array}{l}\text { Straight } \\
\text { wiclth }\end{array}$ & $\begin{array}{l}\text { Curved } \\
\text { length }\end{array}$ & $\begin{array}{l}\text { Curred } \\
\text { width }\end{array}$ & Height & $\begin{array}{c}\text { Sternal } \\
\text { length }\end{array}$ \\
\hline T. porteri ${ }^{1}$ & $36 \frac{1}{2}$ & 31 & $50 \frac{1}{2}$ & 55 & $22 \frac{3}{4}$ & $31 \frac{3}{4}$ \\
\hline T. darwini ${ }^{2}$ & 38 & $2 S$ & 49 & 46 & $20 \frac{7}{8}$ & $32 \frac{1}{4}$ \\
\hline T. darwini ${ }^{3}$ & $48 \frac{1}{2}$ & $34 \frac{1}{2}$ & $56 \frac{1}{2}$ & 62 & 25.7 & 36 \\
\hline$T$. sp. $^{4}$ & $26_{4}^{3}$ & $22 \frac{1}{2}$ & $34 \frac{1}{2}$ & 37 & $16 \frac{1}{4}$ & $22 \frac{9}{10}$ \\
\hline M.C.Z. 11079 & $24 \frac{1}{4}$ & $19 \frac{1}{2}$ & 30 & 32 & $12 \frac{1}{2}$ & \\
\hline 11080 & $21 \frac{1}{2}$ & $16 \frac{1}{2}$ & 27 & $27 \frac{1}{2}$ & $11 \frac{1}{4}$ & \\
\hline 11088 & $27 \frac{1}{2}$ & $21 \frac{1}{4}$ & 37 & $38 \frac{1}{2}$ & $\cdots$ & \\
\hline 11091 & $22 \frac{1}{4}$ & 18 & 28 & $30 \frac{1}{2}$ & $12 \frac{3}{4}$ & \\
\hline 12049 & $11 \frac{1}{2}$ & 9 & 15 & 15 & $5 \frac{3}{4}$ & $10 \frac{1}{4}$ \\
\hline
\end{tabular}

\section{Testudo microphyes Günther.}

Plates 11-20, 38, fig. 3 .

Testudo clephantopus Günther, 1875, Philos. trans. Roy. soc. London, 165, p. 261, pl. 33, fig. A, pls. 37-39, fig. A, pl. 40, fig. A, C, D., pl. 41, fig. B, pl. 42, fig. A, pl. 43, pl. 44, fig. $A-A^{\prime \prime}, C, D$; 1877 , Gigantic land-tortoises, p. 63, pl. 30, fig. A, pl. 42-44, fig. A, pl.46, fig. A, C, D, pl. 47, fig. B, pl. 51, fig. A, pl. 52, pl. 53, fig. $A-A^{\prime \prime}, \mathrm{C}, \mathrm{D}$; Rothschild, 1902, Nov. zool., 9, p. 448, 61s; Heller, 1903, Proc. Wash. acal. sci., 5, p. 53; SieBenrock, 1909, Zool. jahrl. Suppl, 10, p. 532.

Testudo microphyes Güntuer, 1875, Philos. trans. Roy. soc. London, 165, p. 275, pl. 36-39, fig. B; 1877, Gigantic land-tortoises, p. 78 (part), pl. 37, pl. 42-44, fig. B; Rothschuld, 1915, Nov. zool, 22, p. 406,416 .

Testudo güntheri Baur, 1889, Amer, nat., 23, p. 1044; VAN Denburgh, 1914, Proc. Cal. acad. sci., ser. 4, 2, p. 335, pl. 81-92; RothschiLd, 1915, Nov. zool., 22, p. 106, 410.

Téstudo galapagoensis Rotrischild, 1915, Nov, zool., 22, p. 101 (part), pl. 27, 28.

Testudo chathamensis Van Denburgh, 1907, Proe. Cal. acad. sei., ser. 4, 1, p. 4; 1914, 2, p. 323, pl. 6469; Rothschild, 1915, Nov. zool., 22, p. 406, 409, 416, pl. 29, 30.

The speeies Testudo mierophyes was founded on a specimen twenty-two inches and a half in direct length, at the time in the possession of the Royal Institution of Liverpool. It was said to be "a fully adult male," "the smallest of the Galapagos Tortoises," and was supposed to have come from Española Island (Hood). Latel this type was secured by the British Museum and in the publication on the Gigantic Land-Tortoises, 1877, after comparison with Cookson specimens it was said to be "undoubtedly a female" from the north of Isabela Island (Albemarle). The conelusions here recorded after a detailerl

\footnotetext{
${ }^{1}$ Rothschild, Nov. zool., 1903, 10.

${ }^{2}$ Van Denburgh, Proc. Cal. acad. sci., 1907, 1.

${ }^{3}$ liotlısehild, Nov. zool., 1915, 22.

${ }^{4}$ Van Denburgh, Proc. Cal. acad. sci., 1914, 4.
} 
study are that the type is abnormal, somewhat aged, probably a clwarf, and differs so much from the specimens obtained by Cookson as to prevent retention in the same species. The 'Tagus Core specics is considered a new one, and, being one of the largest found on the islands is named $T$. macrophyes (Plate 4, 5).

The type of $T$. microphyes Günther, 1875, was probably not an average individual of the species. The outlines of the original figures by Wesley, are sketched on Plate 11. As seen from above the shape is subelliptical, slightly irregular, and slightly narrower forward. The body is depressed and has a rather low arch on the back. The outline, from the side, is broadly curved from front to rear. Anteriorly in the first and the second vertebral plates there is some de-aent and posteriorly from the middle of the third vertebral the curve becomes steeper and sharper. The curved width is little if any greater than the curved length, certainly not so much greater as in the nearly allied species, T. nigra. Compared with that species the bones of the shell are thicker and heavier, the back is not so high posteriorly. The scales are smooth, the marginals appear to be much worn, the edges of the carapace are thickened and rounded at the edges. The sternum bears more resemblance to that of T. elephantopus than to that of T. macrophyes; it is broad and broadly rounded in front of the humeral extension, and behind the femoral extension, across the anal scutes, it becomes when old nearly or quite truncate. The skull differs from that of $T$. macrophyes from Tagus Cove; it agrees with that of $T$. güntheri from Villamiel.(11066).

Young individuals of about fifteen inches in direct length, Plates 17, 19, purchased on Santa Maria Island (Charles) appear rather smooth, though the striae are sharper in the younger stages. The gular plates are rounded and not separated by a sharp notch. In the specimen, Plate 19, the bone in the anal scutes is nearly truncate and the notch is shallow but the homy scales extend beyond and turn up in points behind it. Specimens of this size have the shallow early indications of the sternal concavity.

Plates 12, 20 represent specimens of about two feet in length of carapace. In this size, with the exception of the blister-like pits, the scales are smooth, the gulars, the anals, and the scallops of the edges are much changed. The back is depressed to different degrees in different individuals and raries in curvature. The swollen flanks of the females indicate that they are fully adult. In cases the notch between the gulars, or that between the anals is obsoletc; in others these scutes have suffered less. The gulars thicken upward; in some examples the anals have hardly changed. 
Specimens of from thirty-one to thirty-eight inches, Plates 14, 16, show the edges of the shells to be more modified and the backs to be more depressed, especially in the male, in which they have become subquadrate. The sternum is nearly truncate, is deeply concave and the slight constriction at the fourth and the eighth pairs of marginals is evident in both sexes. None of the specimens show decided bosses on the areolar spaces of the dorsal scutes.

The specimen, Plate 12, was received in exchange from Van Demburgh, from Villamiel, southeastern Isabela (Albemarle); its affinities are evident on comparisons with his Plates 66, 68, 83, 84, 90, 92, and others. Plates 14, 16 of the present work are photographed from large speeimens brought by Baur from the same locality. Plate 15 shows outlines of $T$. elephantopus Günther, 1875 and 1877 (not of Harlan, 1827), from drawings by Ford of a specimen the history of which was unknown. Much dependence was placed on the skull of the same specimen for distinction from other species. The differences appear to be individual rather than specific. The occipital crest affords the greatest variance; that crest, however, figured in Günther's, 1875, Plate 38, fig. A, and 1877, Plate 43, fig. A, had been broken or mutilated and in its repair took on a peculiar shape not occurring on other specimens. Young to medium sized specimens favor T. microphyes Günther, 1875; the old ones agree better with T. elephantopus Günther, 1875, = T. güntheri Baur, 1889.

On Plates 17 and 18 are figures of No. 4479 M. C. Z. and on Plate 19 is a photograph of No. 4476. These are the smallest specimens of this species in the collection; they were purchased by Prof. Louis Agassiz on Santa Maria. A deseription of No. 4476 will answer about as well for No. 4479, they are so nearly of the same size and appearance. No. 4476 has a rather plump appearance, being well and smoothly rounded on the sides and back. The indentation or concavity on the first to the third marginals is shallow and these scutes are but little turned upward. The indentation of the eighth marginal is not very distinct. The bosses on the vertebrals are low, the most marked being that on the first of the series; there are no bosses on the second and third, and none on the costals. Instead of a sharp ridge along the flank as on $T$. vicina this portion is rounded and smooth, the carina making its appearance far in front, in the fourth marginal, and far back, in the seventh. The declivity in the first vertebral scute, the descent to the neek, is a little steeper than on older specimens; the greatest height is attained in the third vertebral. There is a large area in the central portion of each scale on which the striae are effaced, either by sloughing or by scouring; nearer the edge there are seven or eight more 
distinct striae. From the fourth vertebral to the caudal there is a moderately sharp descent but the first of these seales has not a marked boss. The lines of junction between marginals and costals are moderately straight. The caudal does not extend as far backward as the marginal at either side of it, but curves downward somewhat lower.

The sternum is broad; the abdominals make a long bend from their lowest portion to meet the marginals. The anals form a shallower wotch than that of T. vicina; their hinder angles are more rounded off. The sternal coneavity is shallow, not yet reaching the depth of half an inch in the hind parts of the abdominals. A deep groove near the edges of the scutes (stria of growth) show's that the abdominals have made a greater enlargement than the other scales (Plate 19, fig. 3).

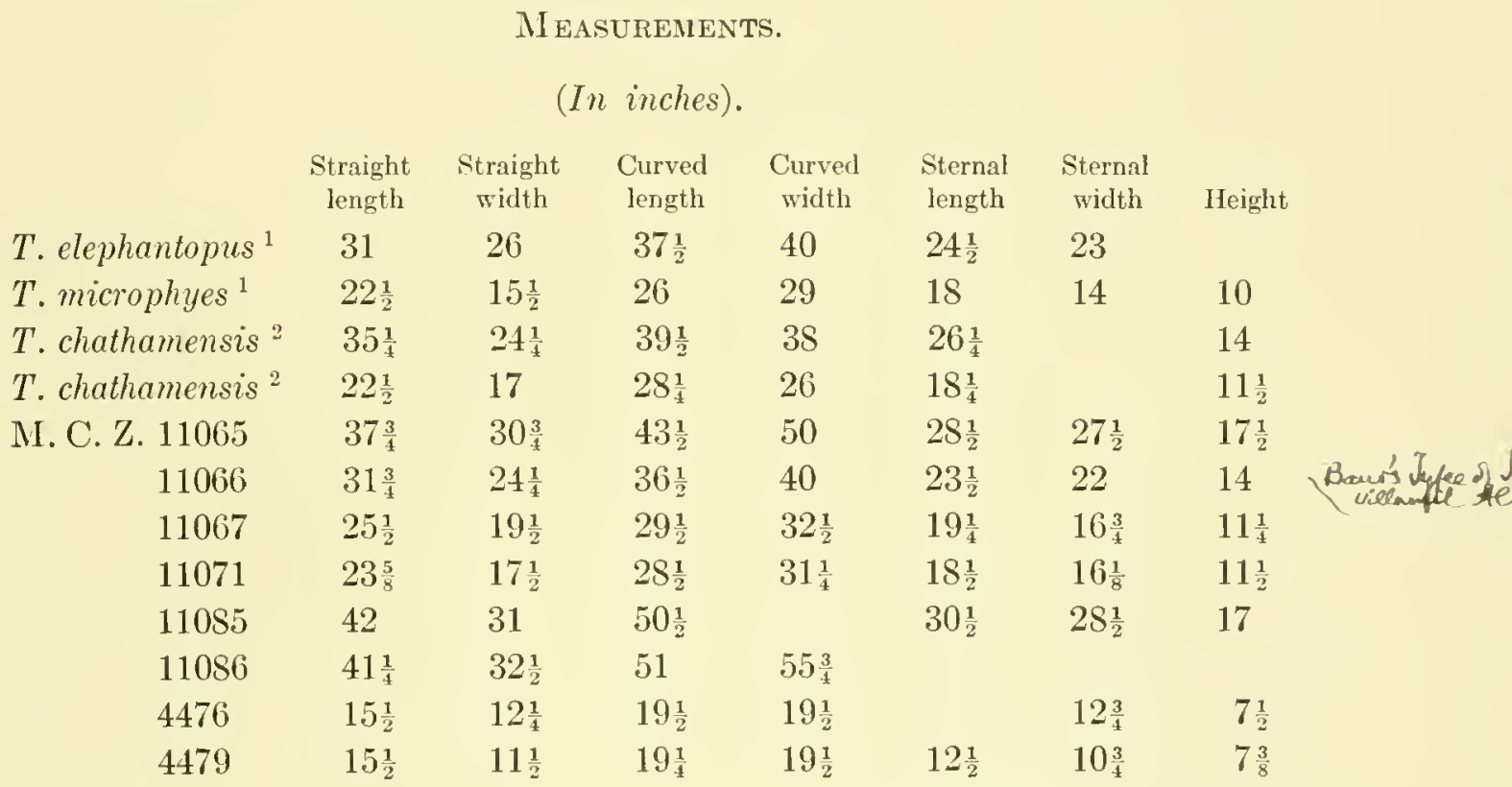

Testudo Clivosa, sp. not.

Plate 21.

This tortoise (Type M. C. Z. 11075) is described from a bony carapace and plastron on which there are seven or eight entire seutes in place. Of its history nothing definite is known. It was supposed to have come from the Mascarenes. Possibly a name and date, "Narraga 1861," may yet help to

1 Günther, Philos, trans., 1875, 165.

${ }^{2}$ Van Denburgh, Proc. Cal. acad. sci., 1907, 1. 
determine the habitat. There is nothing in its structure that would preclude an eventual determination of an origin, either indirect or direct, among the Galapagos. It has close affinities to their species though in some respects its peculiarities do not permit identification with any of which descriptions or figures have been published. Its outlines are suggestive of the wider and shorter individuals of $T$. elephantina Duméril et Bibron. It has two gulars but no nuchal plate.

\begin{tabular}{|c|c|c|c|c|}
\hline $\begin{array}{l}\text { Direct } \\
\text { length }\end{array}$ & $\begin{array}{l}\text { Direct } \\
\text { width }\end{array}$ & $\begin{array}{c}\text { Curved } \\
\text { length }\end{array}$ & $\begin{array}{c}\text { Curved } \\
\text { width }\end{array}$ & Height \\
\hline $25 \frac{3}{8}$ in. & $20 \mathrm{in.}$ & $30 \frac{1}{2}$ in. & $32 \frac{3}{4}$ in. & $12 \frac{1}{4} \mathrm{in}$. \\
\hline
\end{tabular}

Height to nuchal notch 10 , to middle of back $12 \frac{1}{4}$, and to lower edge of caudal scale $1 \frac{1}{2}$ inches. The bones are thin and light, the entire weight, with attached scales, being less than five pounds. All sutures are complete and firmly joined excepting those at the inner edge of the marginals from the first vertebral to the edges of the supracaudal. The bones of the back at the lower edges of the costals are separated from those under the marginals by a space and their only connections are made by the ribs, except at the nuchals and at the supracaudals where they are rigidly united by broad anchyloses. The conditions along the flanks are like those existing on the very young of other species. The scutes are thin and fragile, the areolar spaces are small; the concentric striae are numerous, narrow, and sharp. The carapace is short and broad and is broadly arched on the back. In front from the middle of the second vertebral, through the first, the descent is about as in T. vicina Günther. Fourth vertebral narrow behind, hind edge about $3 \frac{3}{4}$ times in front edge. Seen from above the shape approaches the subquadrangular, owing to a considerable spread and recurvature of the humeral and the femoral marginals. The anterior marginals extend forward and upward, and the posterior extend farther back than the caudal, which is narrow, convex, and curves down and forward at the lower edge. The humeral indentation, on the third marginal, is shallow but the groove from it to the middle of the first vertebral is decided, because of the recurvation of the margimals behind it similar to $T$. elephantopus. The vertebral shields are broader than the costals; each has a high convex boss on the middle, that on the fifth vertebral being especially prominent. Inchuding the areolar space on each costal there is a similar boss. On the plastron the gulars are broad and subtruncate in front, swollen and rounded above the edge and rounded on the angles. The pectorals are short, broad and in contact. 
The coneavity is rather deep, deepest in the hinder halves of the abdominals. The anals are shorter and broader than the gulars; they neet in a shallow noteh behind, below which the edge is swollen, thiekened and bent downward.

\section{Testudo ty Pica, sp. nov.}

Plate 22, 34.

This species (Type M. C. Z. 11072) is one of the nearest allies of T. nigra. Looking downward upon it the earapaee appears subquadrangular and somewhat narrower aeross the humeral section than aeross the mid length or farther back. In the middle of the first vertebral scute there is a prominence and from it a considerable deelivity forward. Behind this vertebral the dorsal areh is low and regularly eurved to the areolar space on the middle of the fourth vertebral, which is prominent and from which the descent is steeper to the space on the fifth vertebral, which latter is yet more prominent, almost acuminate. From this boss the descent to the eaudal is nearly vertieal. The upper margin of the fifth vertebral is narrow, being less than one fourth of the width of the lower edge. The convexity of the other vertebrals and of the eostals is low. The marginals are comparatively large; the anterior three pairs and the posterior four pairs are reverted and form seallops along the margins. Marked grooves oecur from the humeral and the femoral notches along the inward edges of the marginals. Along the flanks the costals and the marginals are suffieiently convex to give a full and plump appearance to the body. The lower edge of the caudal is not bent forward; it inelines straight back and downward. Axillary and inguinal seales are single. In the femoral seetion the marginals are somewhat wide and pass baek and upward; the lower edge of the eaudal descends sharply below the marginals. This form is distinguished from all its nearest allies by the prominent subaeuminate boss of the fifth vertebral.

Sternum subtruncate in the gulars with the angles rounded off. On the lower surface the concavity is deepest at the junetion of the femorals with abdominals; it shallows gradually forward and more rapidly outward and backward. The anal scales are hardly swollen at all; between them the noteh is of moderate depth. In front the gulars are swollen upward. Solidity of bones and anchylosis of sutures are probably the effeets of a considerable age. The color was nearly a uniform black. 


\section{MeASUREMENTS.}

(In inches).

\begin{tabular}{|c|c|c|c|c|c|c|c|c|c|}
\hline M. C. Z. & $\begin{array}{l}\text { Direct } \\
\text { length }\end{array}$ & Width & $\begin{array}{l}\text { Curved } \\
\text { length }\end{array}$ & Width & Height & $\begin{array}{l}\text { Sternal } \\
\text { length }\end{array}$ & Width & Gulars & Anals \\
\hline 11072 Туре & 24 & $17 \frac{1}{2}$ & 33 & 30 & $11 \frac{3}{4}$ & 19 & $16 \frac{1}{4}$ & 4 & 3 \\
\hline 5260 & 29 & $22 \frac{1}{4}$ & 34 & $36 \frac{1}{2}$ & $13 \frac{5}{8}$ & 23 & 20 & & \\
\hline
\end{tabular}

The type, Plate 22, differs from specimens of T.nigra, equal in size, in being less convex on the back, the arch from the first to the fifth vertebral scale being lower, as also that across the back; the marginals above the legs are entire, not worn and thickened, and form greater arches, the eighth marginal is wider on its uppel edge; the bones of the sternum above the gulars and the anals are not swollen downward; the anal notch is a little more than $90^{\circ}$; and the fifth vertebral scale is narrow on its upper edge and bears in its upper half a steep and sharp prominence. On similar comparison with $T$. microphyes it is seen that nearly all of these differences are pertinent.

Specimen described is from the Boston Society of Natural History. Dr. C. F. Winslow collection (See Proc. Boston Society Natural History, 1S61, 10 p. 59).

\section{Testudo nigra Quoy et Gaimard.}

Plates 23-33, 35, 36 .

Testudo nigra Quoy Et Gamard, 1S24, Voyage Uranie et Physicienne zool., p. 172, pl. 40; Cuvier, 1829, Regne anim., 2, p. 10; Voigt, 1832, Thierreich., 2, p. 9; Demérir ét Brbrox, 1835, Erpétol. génér., 2, p. 115; Wiegmain, 1S35, Nov. act. Leop.-Carol., 17, p. 11S, pl. 13; Strradch, 1862, Mem. Acad. St. Petersb., ser. 7, 5, p. S5; 1S65, Verth. schildkr., p. 29; Boulenger, Cat. Chelon., p. 170; Sтradeh, 1890, Bemerk. schildkr., p. 53.

Testudo californiana QUor ET Gammand, 1S24, Bull. sci. nat., 1, p. 90, pl. 11.

Testudo clephantopus Jacksox, Boston journ. nat. hist., 1, p. 443, pl. 10, 11; VAx Denburgh, 1914, Proc. Cal. acad. sci., ser. 4, 2, p. 245, 316, pl. 55, fig. 2, pl. 56, fig. 1.

Testudo galapagoensis Baur, 1S89, Amer. nat., 23, p. 1044; Günther, 1902, Nov. zool., 9, p. 184, pl. 16-21; Heller, 1903, Proc. Wash. Acad. sci., 5, p. 53; Siebenrock, 1909, Zool. jalırb. Suppl., 10, p. 553; Rotuschild, 1915, Nov. zool., 22, p. 404, pl. 23-26.

Testudo wallacei Rothschild, 1902, Nov. zool., 9, p. 619; Heller, 1903, Proc. Wash. acad. sci., 5, p. 54; Siebenrock, 1909, Zool. jahrb. Suppl., 10, p. 533; Rothschild, 1915, Nov. zool., 22, p. $407, \mathrm{pl} .31,32$.

The type described and figured by Quoy and Gaimard was said to be twelve inches long and eight inches wide. It was obtained by Freycinet at the Sandwich Islands (Hawaiian) from the Captain of a vessel that had recently (about 1S18) arrived from California. There is no mention of the original habitat. The figures published by the describers are sketched in outline on Plate 23, fig. 2, 3. Plate 23, fig. 1, is from a drawing published by Wiegmann of a 
specimen weighing a hundred and twenty-five pounds, after losing forty pounds of its weight in a year's royaging, before being bought by Meyen from a Galapagos Whaler at Honolulu.

The more important items in the description are in the words of the authors:- "Testudo, toto corpore nigro; testa gibba, seutellis dorsalibus priori posteriorique altius in medio elevatis, cunctis loricae margine striatis, lateribus subcarinatis. Les enveloppes de cette tortue ont douze pouces de longueur et huit de largeur. La carapace est très bombée, arrondie, et le disque composé de treize ecailles; des einq qui forment la rangée du milieu, deux ont un diametre transversal plus considérable que les autres; plusieurs sont protubérantes à leur centre, mais surtout l'antérieur et la postérieur. . . Le plastron se compose de seize pièces, dont huit en avant, une paire beaucoup plus large au milieu, et six en arrière: les deux premières sont arrondies et courbées en bas; les postérieurs assez profondément echancrées. Toutes offrent des stries concentriques et parallèles entre elles."

Duméril et Bibron, Erpétol. Génér., 1835, 2, p. 118, give the length of the type as $34^{\prime \prime}$, and those of a larger carapace as "Long. (en dessus) $71^{\prime \prime}$; haut. $28^{\prime \prime}$; larg. (en dessus) $86^{\prime \prime} . "$

In a description taken from a specimen of about eleven inches in length (Plate 24, probably an average individual), the form of the species is approximately a short oval in which the ends do not converge enough to render them at all pointed. In fact the shape would not be badly described as subtruncate with the front a little the more rounded and the opposite extremity, across the candal scale somewhat more truncate. The proportions of an individual of about this length have a width of nearly three fourths and a height of about one half of the straight length. A flattening on the back is usually most apparent across the third and the fourth of the vertebral plates. The descent from this portion is more gradual forward in the first and the second vertebrals and more rapid backward through the fourth and the fifth vertebrals and the caudal. The arch across the middle of the back is low and broad. The entire series of the marginal plates forms seallops the more prominent of which are the first to the fourth and the eighth to the hindmost, inclusive, at each side of the median line. The areolar spaces on the costal scales, and on the vertebrals are a low convex, those of the first and the fifth vertebrals being most prominent. The general outline is rather smooth or even. The concentric striae are strongly marked on the scales of all the young. At the fourth and at the eighth of the marginals, on each side, the notches at the outer angles of the bridge are 
apparent, shallow, but distinet. The second, third, and the fourth marginals, toward their outward ends, are slightly curved upward; the first pair above the neek ineline downward slightly; the hindmost one, the caudal, extends down abruptly and curves forward at the lower edge; and on the fourth to the eighth marginals, along the flanks, there is a low blunt keel.

The width of the plastron is about nine elevenths of its length; the concavities on its lower surface are so shallow at this age they may be overlooked. The gular extremity is subtruneate, rounded, and a trifle swollen upward at the end in front. There is a weak noteh between the gulars; they turn downward slightly at the front edge. The lateral outline of each humeral scale is convex in its hinder half and a very little concave anteriorly, forming a feeble sigmoid; and in the femoral section the lateral outline of eaeh femoral seale is strongly convex. The anal seutes are separated by a deep noteh, and each seale is longer than wide. In the young as in the old there is a considerable amount of individual variation, in outlines, prominence of areolar spaces, smoothness, and in measurements. The specimens in Plates 24, 25, 26 are a little larger than the type to which the name $T$. nigra was originally applied; they are part of the lot secured by the Hassler Expedition on Santa Maria Island (Charles).

Plates 32 and 33 represent a group of medium sized speeimens, about twice the length of the type. They exhibit considerable changes worthy of note in a specific description. There has been an inerease in direct length as compared with the direct width and height, and an inerease in the width across the curvature beyond that of the eurved length as the width and bulging roundness of the body increases, posteriorly there is a comparative increase in the height near the middle of the fourth vertebral scale and, in males especially a widening or flattening of the arches of the back without corresponding increase in height. The muchal height has beeome greater, the humeral and the femoral arches have become higher and wider proportionally, and some of the marginal plates are curved and thicker at the free outer edges. The caudal plate has acquired a greater prominence as the marginals at its sides have worn away. The notehes on the sides at the fourth and the eighth marginals, near the angles of the bridge, and the groores above them are deepened; compression of the flanks anteriorly has steepened the sides and the saddle-shape, so called, has been increased thereby. From the seales the striae have disappeared in great measure, as also has the low ridges from the fourth to eighth marginals.

In both sexes the plastron has become deeply coneave; its ends are wider 
and more rounded. Between the anal plates the notch is more shallow; gulars and anals are widened, the former have thickened upward, the latter are swollen downwards. Along each side of the medial concavity there is a great rounded prominence. An extreme form of the female in medium size is that shown on Plate 33, a more common form on Plate 32.

Specimens of about three times the length of the types are figured in Plates 29, 30, 31, 35. They emphasize the tendencies prominent on those of the medium sizes besides indicating others acquired on approach of maturity or depending on age, together with those dependent wholly or partly on sex. In the majority these features will be sufficiently evident from the illustrations. The large females on Plates 31, 35 as compared with those of the smaller group, Plate 32, have more fulhess or roundness in the vertebral and in the costal plates and have much greater concavity in the sternum. They are even more concave than in the male, Plates 29, 30, fig. 3; the latter is more elongate and more depressed on the back and a trifle narrower across the humeral region. Being less deep in the sternal concavity may be a peculiarity of this specimen as the difference is not great. Plate 28, fig. 1 and Plate 31 pertain to the female described in Dr. Jackson's article, The anatomical description of the Galapagos tortoise, Boston Journal of Natural History, 1837, 1, p. 443. Plate 29 is the male discussed in the same article; it is outlined on Plate 30, from Günther's figures in the Nov. Zool., 1902, 9, Pl. 16 and 17.

These specimens were secured by the U. S. S. Potomac. Santa NIaria (Charles) was the only island of the group visited. In the latter part of May, 1834, the vessel was at Boston, and in June the donation of "two gigantic Galapagos tortoises (living) weighing near three hundred and twenty pounds each, by Capt. John Downes (U.S. Navy) is recorded by the Boston Society of Natural History. The Potomac was at Santa Maria from August 31 to September 10 , according to Reynolds's account, p. 547, "a large number of the crew were daily on shore after terrapin, and frequently exposed throughout the day to a hot sun, with these immense animals on their backs, travelling over the broken lava." The male of the Dowmes and Jackson specimens was examined by Baur and became the type of his T. galapagoensis. Afterward it crossed the Atlantic and was described and figured by Günther, 1902. The photograph, Plate 35, a fine specimen inscribed with the legend "SHip ABigail 1835 Bj. Clark Master," is probably from a native of the same island, Santa Maria. The ABIgall was a whaling ressel from New Bedford, Mass. The specimen is No. 11064 M. C. Z., received from the Boston Society of Natural History in exchange. 
MEASUREMENTS.

(In inches).

\begin{tabular}{|c|c|c|c|c|c|c|c|}
\hline M. C. Z. & $\begin{array}{l}\text { Straight } \\
\text { length }\end{array}$ & $\begin{array}{l}\text { Straiglit } \\
\text { width }\end{array}$ & $\begin{array}{l}\text { Curved } \\
\text { length }\end{array}$ & $\begin{array}{l}\text { Curved } \\
\text { width }\end{array}$ & Height & $\begin{array}{l}\text { Length of } \\
\text { sternum }\end{array}$ & $\begin{array}{l}\text { Width of } \\
\text { sternum }\end{array}$ \\
\hline 4477 & $10 \frac{3}{4}$ & $s$ & $13_{4}^{1}$ & $13 \frac{1}{2}$ & $4 \frac{7}{8}$ & $9 \frac{3}{8}$ & $7 \frac{3}{4}$ \\
\hline 4480 & $12 \frac{7}{8}$ & $10 \frac{1}{8}$ & $16 \frac{1}{2}$ & $17 \frac{1}{4}$ & $6 \frac{1}{2}$ & $11 \frac{1}{4}$ & $9 \frac{1}{4}$ \\
\hline 4478 & $15 \frac{1}{4}$ & $11 \frac{1}{2}$ & $19 \frac{1}{4}$ & $19 \frac{1}{2}$ & $7 \frac{1}{2}$ & $12 \frac{1}{2}$ & $10 \frac{1}{2}$ \\
\hline 11074 & $24_{4}^{3}$ & $15 \frac{1}{2}$ & $30 \frac{1}{2}$ & 32 & $12 \frac{1}{4}$ & $19 \frac{1}{2}$ & 18 \\
\hline 11070 & $38_{4}^{1}$ & 28 & 45 & $46 \frac{1}{2}$ & $17 \frac{1}{2}$ & $28 \frac{1}{2}$ & 26 \\
\hline 11069 & $42 \frac{1}{2}$ & $32 \frac{1}{4}$ & $52 \frac{1}{2}$ & 56 & $20 \frac{3}{4}$ & 33 & 30 \\
\hline 1905 & $2 S$ & $21 \frac{1}{2}$ & $32 \frac{1}{2}$ & $36 \frac{1}{2}$ & $13 \frac{1}{4}$ & $21 \frac{1}{4}$ & $19 \frac{1}{4}$ \\
\hline 1904 & $27 \frac{1}{2}$ & $21 \frac{5}{5}$ & 35 & 38 & $14 \frac{1}{4}$ & $21 \frac{1}{8}$ & 20 \\
\hline 11064 & $41 \frac{1}{4}$ & 33 & 52 & 59 & $22 \frac{7}{8}$ & $31 \frac{1}{2}$ & 29 \\
\hline 4668 & 26 & $20 \frac{5}{8}$ & 33 & 34 & 13 & 20 & 18 \\
\hline
\end{tabular}

For the type of Testudo wallacei these neasurements are given by Rothschild, 1915:

$\begin{array}{cccccc}\begin{array}{c}\text { Straight } \\ \text { length }\end{array} & \begin{array}{c}\text { Straight } \\ \text { width }\end{array} & \begin{array}{c}\text { Curved } \\ \text { length }\end{array} & \begin{array}{c}\text { Curved } \\ \text { width }\end{array} & \text { Height } & \begin{array}{c}\text { Sternal } \\ \text { length }\end{array} \\ 31.25 & 23.50 & 39 & 37.50 & 15.65 & 24.25\end{array}$

The straight length in the original description was 32.25 inches.

\section{Testudo elephantopus Harlan.}

Plates 37, 38, fig. 1, 2, 39-42.

Testulo elephantopus Harlan, 1527, Journ. Acad. nat. sci. Plil., 5, p. 2St, pl. 11.

Trstudo ephippium Gứxtner, 1575, Philos. Trans. Roy. soe. London, 165, p. 271, pl. 34, 35, fig. B, pl. 37, fig. C, pl. 38, fig. C, pl. 39, fig. C, pl. 42, fig. 3, pl. 44, fig. B, pl. 45, fig. A, B; 1877, Gigantic land-tortoises, p. 81, pl. 31, 32, fig. B, pl. 39, 42-14, fig. C, pl. 51, 53, fig. B, pl. 5t, fig. A, B; BAUR, Amer. nat., 23, p. 1040; Gínther, 1896, Nov. zool., 3, p. 329, pl. 20-22; Lidth, 1895, Notes heyden mus., 20, p. 126, pl. 3, 4; Gidoow, 1901, Cambridge nat. hist., 8, p. 378; Heller, 1901, Pror. Wish. acad. sei., 6, p. 57; Berk, 1903, 7th Ann. rept. N. Y. zool. soc., p. 172; Siebenrock 1909, Zool. jałırb. Suppl. 10, p. 534; Jan Dexburri, 1914, Proe. Cal. sead. sei., ser. 4, 2, p. 306 pl. 39-52; Rothschuld, 1915, Nor. zool., 22, p. 404.

Testudo ahingdonii Güntier, 1877, Pror. Zool. soc. London, p. 66; Gigantic land-tortoises, p. 85, pl. 40, 11, 45, fig. D, F, pl. 45-50; Heller, 1903, Pror. Wish. acad. sei., 5, p. 57; Vax Dexbcrgh, 1914, P'roc. Cal. Acarl sci., ser. 4, 2, p. 296, pl. 24-29; Rothsсніlo, 1915, Nov. zool., 22, p. 403, pl. $21,22$. Tesendo berhi Rotrisuld, 1901, Nuv. zonl., 8, p. 372; Jleller, 1903, Proc. Wash. acid. sci., 5, p. 59;

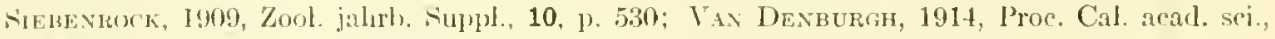
ser. 4, 2, p. 303, p]. 31-38; Rothschild, 1915, Nov. zool., 22, p. 404.

Testudo bedsi Heller, 1903, J'roc. Wash. :1ead. sci., 5, p. 59.

Testulo hoodensis Iax Denburgn, 1907 , P'roc. Cat. acal. sci., ser, 4, 1, p. 3; 1914 , ser. 4, 2, p. 313, pl. 52-55; SiebFirock, 1909, Zool. jahrh. Suppl., 10, p. 535

Testudo phantastica VAx Denbergh, 1907, Proc. Cal. acad. sei., ser. 4, 1, p. 4; Siebenrock, 1909, Zool. jalırb. Auppl., 10, p. 535; Van Denburgh, 1914, Proc. Cal. acad. sci., ser. 4, 2, p. 299, pl. 30 
What ressel earried Harlan's tortoises to Philadelphia may not be known. They may have been brought by the same expedition bringing those to New York, under Capt. David Porter, L.S. N., though no doubt there were numerous opportunities for transportation in the ten years or more elapsing after the visit of Porter and before Harlan's date of publication. The references in the latter, mainly to Porter's narrative, do not fix upon the donor, the time of arrival, or the island from which specimens were brought. Harlan's deseription applies to such forms as are compressed and narrowed above and in front of the shoulders, rather than to any of the others. The dimensions given correspond sonewhat elosely with those of the specimen figured below on Plates 37, 38. The yellow blotches on the "under jaw and upper part of the throat" do not distinguish from the form described as Testudo ephippium Günther, 1875, and its elosest allies.

Harlan's measurements in inches, are:

Length of the back-plate, following the curvature 21.6 Breadth of the back-plate, following the eurvature 22.6 Vertical diameter, or height of the animal 9 Lateral diameter 14 Cireumference of the body 36

Evidently Dr. Harlan had specimens other than his type under examination. For he says, p. 287, "The animal which is the subject of the present observations, is no doubt young, although larger than a similar species which lately lived for several months in the Philadelphia MIuseum. If we are permitted to judge from the shortness of the tail, and still less certain sign, the planeness of the sternum, our specimen is a female. Its weight is forty pounds." On page 292 he remarks "The present specimen is living in the possession of Mr. Whitton Evans. For the drawings which accompany the description we are indebted to Dr. S. C. Morton." February 27, 1827, some months after the reading of his paper, September 5, 1826, the Museum recorded mention of the gift of a Testudo elephantopus from Richard Harlan, M. D., but did not state whether it was the type specimen, whether it was the one that had been in the possession of Mr. Evans, or whether it had been drawn by Dr. Morton. After the efforts of Günther, Baur, Rothschild, Van Denburgh, and the authorities of the Philadelphia Academy there are few grounds remaining for hope of tracing the type from recorded history. The only attempt in this article is marle in comparisons of a specimen, probably of the same species, as nearly as may be of the size of the type with the description and the drawings. The speeimen selected is 
No. 11063, M. C. Z., an exchange from the Boston Society of Natural History of which nothing more of the history is now known. It is suggested that it may have served as Harlan's type for description or Morton's for drawing.

The direct length of the type would be somewhat near seventeen inches. As for the drawings Dr. MIorton drew them from a living indiviclual which probably made aceurate measurements difficult. The outlines on Plate 37, fig. 2; 3, are from the original illustration. The rertebral series of plates was about twice as wide as it should be; only half the width could be seen from the artist's point of view. The seales nearest the feet also bore evidence of much uncertainty. On the same Plate 37 , fig. 1, are the outlines of a carapace making the nearest approach of those in the collection to what Harlan's type may have been. Plate 38, fig. 1, 2 show this carapace, with a sternum, fig. 3, that was fastened to it, by mistake no doubt as it belongs to a different species. In direct length this earajace is more than sixteen inches. Compared with $T$. micina it lacks the dome-shape, is more elongate, is less broadly curred on the back and is narrower and higher in front. Placing this figure side by side with that of Plate 39, from a specimen of thirty-three inches, of the same species, brings out the close correspondence of the two. Seen from above the main difference in outline is due to wear of the reverted marginals on the older individuals. On the smaller one the small areolar spaces are yet indicated and the striae are yet present, but have begun to show signs of wear.

In connection with Harlan's paper another series of measurements is given on page 292 of the Journal of the Philadelphia Academy of Natural Seience, and on page 196 of the Med. Phys. Researehes, in a note by DeKay: these are:

$\begin{array}{lll}\text { Length } & 25 \text { inches } \\ \text { Breadth } & 19.5 \text { inches } \\ \text { Height } & 13 \text { inches }\end{array}$

These dimensions may have been taken from specimens of either of several species: they were not taken from Harlan's type and have no importance in the history of the species. Evidently the length and the width were taken directly instead of over the curvature.

As seen from above, the carapace of a specimen of about two feet in length. Plate 41, has an outline that is oblong with rounded ends. It has a width of about three fourths of the length; in front of the mid length the shape is narrower, and more rounded; behind the middle it widens somewhat and above the tail it becomes subtruncate. The greatest height is nearly one half of the length and the outline eurves with some regularity from the third vertebral 
seute back and downward to the lower edge of the supracaudal, which last extends back about as far as the marginal at each side of it. In the forward half of the body the back retains its height, even rises in males or some old females, or eurves down toward the nuchal notch in most females and the young. Aeross the first pair of costal seutes the body is compressed into a blunt angle with its apex in the foremost vertebral; from this seale a groove descends along the hinder edges of the reverted marginals of the foremost three pairs and ends at or in the fourth marginal at each side. In front the opening into the carapace is nearly two thirds as high as it is wide, narrowing upward. The marginals form scallops along the edges. Similar to that at the fourth there is another indentation in the eighth marginal of each side, from which on the upper sides each of the posterior three pairs of marginals forms a groove to the caudal seale, by the recurvature of the scales. The concentric striae are present except on some old individuals; the areolar spaces are moderately larger and more or less convex and prominent; they are smooth except perhaps on scales of the very young.

On the sternum the gulars are broad, about five sevenths of the width of the anals; they are rounded in front and have a slight notch between then. The outer edges of the humerals are concave, in large specimens; they are longer than the femoral seutes. The peetorals are short, but meet on the median line. The anal extremity of the sternum is short, broad and subtruneate behind. The anal seutes are broadel than long, are thickened and swollen downward, and are partly separated by a noteh below, much like that on specimens of T. vicina. The sternum is eoncave from the anals to the gulars; the concavity is greatest from the femorals through the hinder halves of the abdominals, farther forward it beeomes shallow and disappears; it is less marked in females and is absent in young. The specimen to which particular reference is made, Plate 41, was secured by Dr. Baur on Pinzon (Dunean) Island. The lateral ridges on the marginals of the flank are low; they become weaker with age.

Females of twenty-one inches from the same island are higher and more arched on the back, less broadened posteriorly, more declivous in the first rertebral shield and are less coneave in the sternum. With age the length becomes greatel as compared with the width; this with the worn and broken seales of the second and the third pairs of the anterior marginals induces indiridual differenees which might lead to selection as types of new species. The color of $T$. elephantopus in general is a black or blackish brown, marked with yellow in places on the lower surface. This speeies, including its varieties, is one of the most distinct of the Galapagos tortoises. The variations of indi- 
viduals at different ages, or in different sexes, are such that measurements taken of specimens and reduced to percentages of the direct length parallel those from the other localities to so great an extent that they are of no real assistance in determining varieties or species.

Tesiudo elephantopus Harlan has under various names been reported from five of the islands:- Española (Hood), Pinzon (Duncan), North Isabela (Albemarle), Fernandina (Narborough), and Pinta (Abingdon). As will be seen by reference to the chart, Plate 1 , this distribution might have been effected entirely by the currents after the species had secured a location on Española or it may in part have been brought about by the intervention of man. The agency of the currents, from the directions indicated by the arrows on the chart. is entitled to much favor. For it is sheer assumption that denies the possibility of drift and establishment by its agency on either of these localities to an animal of such buoyancy, as also that denying ability to swim or otherwise exert itself in the water to a creature possessed of so much muscular ability, endurance, and persistence in walking and climbing. While the buccaneers, the whalers, and the explorers have had something to do with distributing the tortoises since the discovery of the islands by the whites there is a possibility that earlier introductions perhaps including the earliest of all were due to aboriginal navigator's of the times of the Incas or farther back. Considering the possible means of distribution, the amount of differentiation from such a species as $T$. tabulata, Plate 2, the rapidity of growth the variability of the individual it appears unnecessary to go back to the Tertiary or perhaps more than a few generations for the first appearance of the tortoises in the Archipelago.

Among five so-called species placed under $T$. elephantopus there may be one or more entitled to varietal rank. All of them have been styled races, whatever that may have meant, but the indiridual descriptions given do not supply the details necessary for characterization.

The original measurements in inches, of several so-called species are:-

T. ephippium Günther, 1875

\begin{tabular}{cccccccc}
\multicolumn{2}{c}{$\begin{array}{c}\text { Straight Straight } \\
\text { length }\end{array}$} & Curved & Curved & Sternal & Sternal & \\
33 & $23 \frac{1}{2}$ & 40 & 40 & 24 & $21 \frac{1}{2}$ & 17 \\
7 & 5 & $9 \frac{1}{2}$ & $8 \frac{1}{2}$ & $4 \frac{3}{4}$ & $6 \frac{3}{4}$ & $3 \frac{1}{2}$ \\
38 & $22 \frac{1}{2}$ & $40 \frac{1}{2}$ & 38 & 26 & $21 \frac{1}{2}$ & $19 \frac{1}{2}$ \\
$31 \frac{1}{4}$ & $21 \frac{1}{2}$ & $40 \frac{3}{4}$ & 36 & $25 \frac{1}{4}$ & & $16 \frac{3}{10}$ \\
$22 \frac{1}{5}$ & $17 \frac{1}{2}$ & 27 & $24 \frac{8}{10}$ & $19 \frac{7}{10}$ & $11 \frac{1}{5}$
\end{tabular}

T. abingdonii Gïnther, 1877

T. becki Rothschild, 1901

T. hoodensis van Denburgh, 1907 $34 \frac{1}{2}$ $24 \quad 42$ 41 24 
Measureanents.

(In inches).

\begin{tabular}{|c|c|c|c|c|c|}
\hline $\begin{array}{l}\text { Straight } \\
\text { length }\end{array}$ & $\begin{array}{l}\text { Straight } \\
\text { width }\end{array}$ & $\begin{array}{l}\text { Curved } \\
\text { length }\end{array}$ & $\begin{array}{l}\text { Curved } \\
\text { wiclth }\end{array}$ & Height & \\
\hline $11063 P^{P} .388^{\prime} /-2.16 \frac{1}{4}$ & $11 \frac{3}{8}$ & $19 \frac{1}{2}$ & $19 \frac{3}{4}$ & $7 \frac{3}{5}$ & \\
\hline 11068 Pिat 41.25 & $18 \frac{1}{2}$ & 29 & 30 & $12 \frac{1}{2}$ & \\
\hline $11083 \quad 22$ & $15 \frac{1}{2}$ & 24 & $25 \frac{1}{2}$ & & \\
\hline 11084 & $11 \frac{3}{4}$ & $1 S \frac{1}{2}$ & $18 \frac{3}{4}$ & & \\
\hline 11081 & 15 & 25 & $24 \frac{3}{4}$ & $10 \frac{1}{2}$ & \\
\hline 11082 & 15 & 25 & $25 \frac{1}{2}$ & 11 & \\
\hline 11089 & 21 & $35 \frac{1}{2}$ & 33 & & \\
\hline
\end{tabular}

Number 11063, Plate 38, fig. 1, 2, was received in exchange from the Bost. soc. Nat. Hist. Numbers 11081-11084, and 11089 were purchased of F. B. Vebster.

Plate 37, fig. 2, 3, are outlines from Harlan and fig. 1 is a lateral sketch from No. 11063. Plate 38, fig. 3, is a view of the stermum of T. microphyes. Plate 39 gives the outlines of Günther's figures of the type of his Testudo ephippium. Plate 40 the outlines of Günther's figures of Testudo abingdoni from Pinta (Abingdon), Plate 41 represents a 25 inch specimen (M. C. Z. 11068) brought by Baur from Pinzon (Duncan). Plate 42, fig. 2, 3, presents outlines of a cast by Webster of a specimen from Pinzon, and figure 1, a dorsal view of another cast by Webster from Isabela (Albemarle) said to be from T. becki.

The type of T. ephippium Gïnther, 1875, was a specimen in the Museum of Science and Art, Edinburgh. Nothing was said to be known of its history, but Porter's, 1822, description of the tortoises of Charles Island (Santa Miaria) applied so well the author had no doubt the type came from that island. In 1877 in the Gigantic Tortoises this is repeated on p. S1, but on p. 11 and on Plate 39 it is ascribed without question to Indefatigable (Santa Cruz). It appears to have been the only tortoise from the Archipelago in the Edinburgh Museum; had there been another it would not have escaped mention. Baur, 1859, found that Captain Basil Hall had risited Abingdon (Pinta) (the only island of the group landed upon) in January, 1822, and remarked, in his Journal, concerning the tortoises "we took some on board, which lived for many months, but none of them survived the cold weather off Cape Horn. I preserved one in a cask of spirits, and it may now be seen in the MIuseum of the College at Edinburgh: it is about medium size." The measurements given are those of a specimen of about the same size as the type of T.ephippium. Baur took the 
matter up with Dr. Traquair who replied "I have to say that I have had the records of the old College Museum searched for information as to the specimen of Testudo ephippium figured and described by Dr. Günther, and the only entry which we can find which can possibly have any reference to that specimen is one in the year 1822-23 of a 'Large Turtle from South Sea - Captain Basil Hall.'" From this Baur reached a most logical conchsion that the type of $T$. ephippium, 1875, and that of T. abingdonii, 1877, were both from Abingdon island. By comparisons of other specimens with the descriptions and figures he decided that they belonged to a single species. Revision of the matter tends to confirm this, adding both names to the synonymy of T.elephantopus Harlan, 1827, and including as synonyms of the same species $T$. becki, $T$. hoodensis, and T. phantastica. The types of T. elephantopus, T. ephippium, T. becki and T. hoodensis represent young to medium ages; T. abingdonii and T. phantastica the old and very old. 


\section{EXPLANATION OF THE PLATES.}

The outlines are from drawings of Samuel Garman. The photographs are from the negatives of George Nelson. 
PLATE 1.

Jagus Corr lrabsla Albumarke Banks Bay Coublam mantaine Sabcla 


\section{PLATE 1.}

The Galapagos Islands.

Reduced from chart 1798 U.S. Hydrographic Office, 1915. The arrows indicate the direction of the currents. 


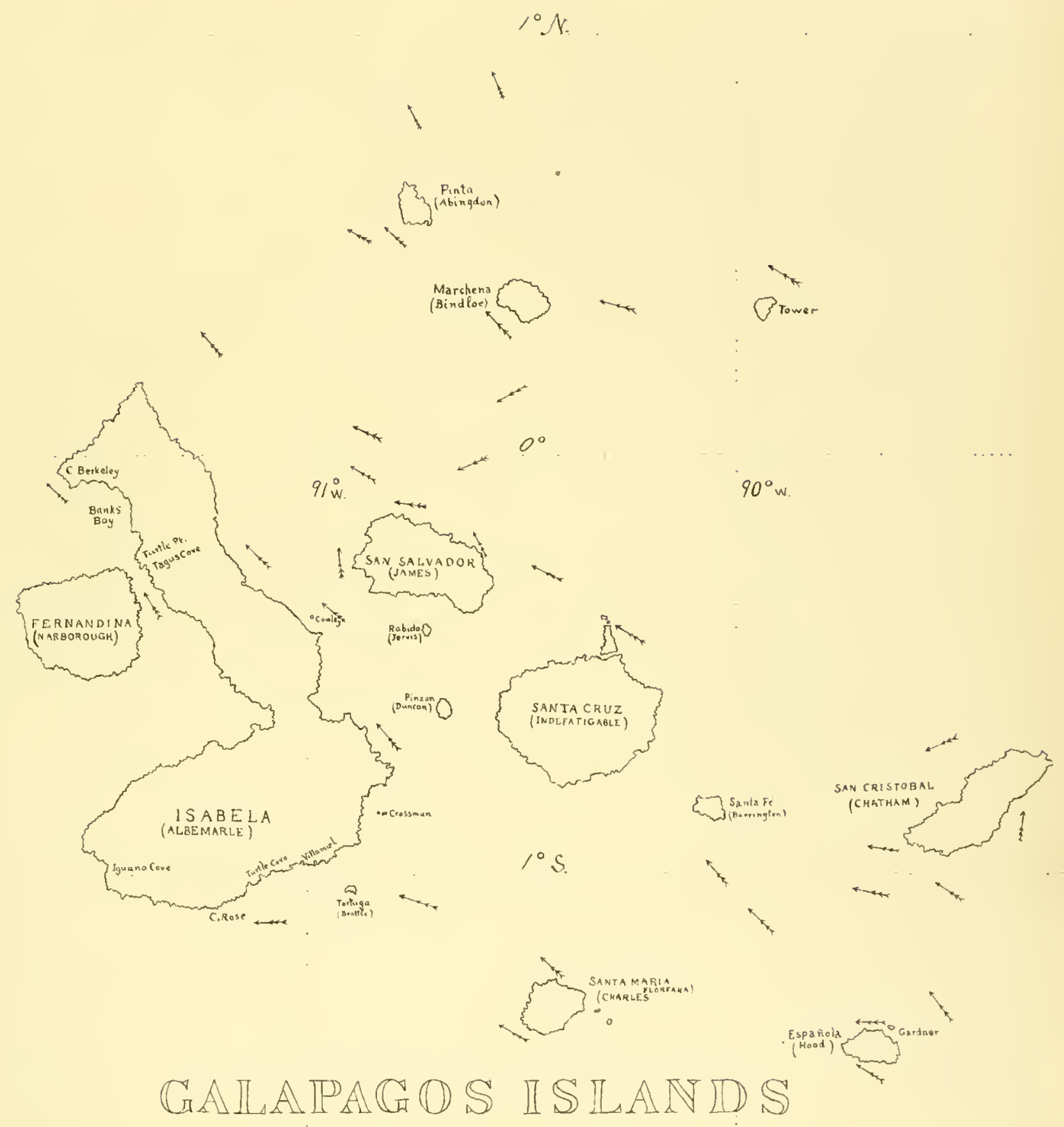



PLATE 2. 


\section{PLATE 2.}

Testudo tabulata Walbaum, 1782.

Page 270

1 ventral, 2 dorsal, 3 lateral.

M. C. Z. 12050 . Porto Rico. Length $22 \frac{1}{2}$ inches. 


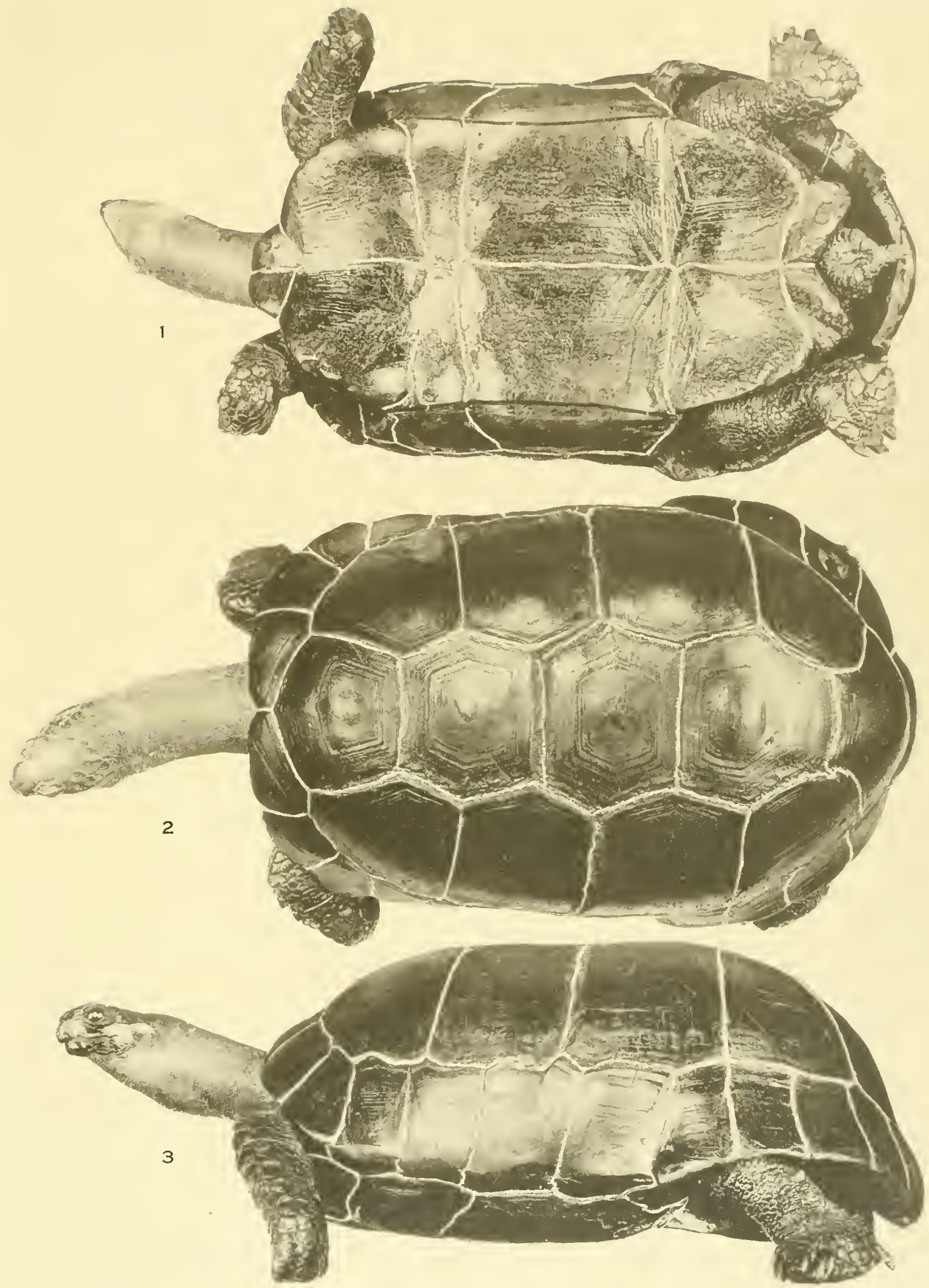



PLATE 3. 
PLATE 3.

Testedo Macrophyes Garman, 1917.

Page 273

1 ventral, 2 dorsal, 3 lateral.

From Günther, 1877, Gigantic tortoises, Plate 38. (T. microphyes Günther, 1S77, nec 1S75).

British Museum, CoTYPE. North Isabela (Albemarle). Length 25 inches. 

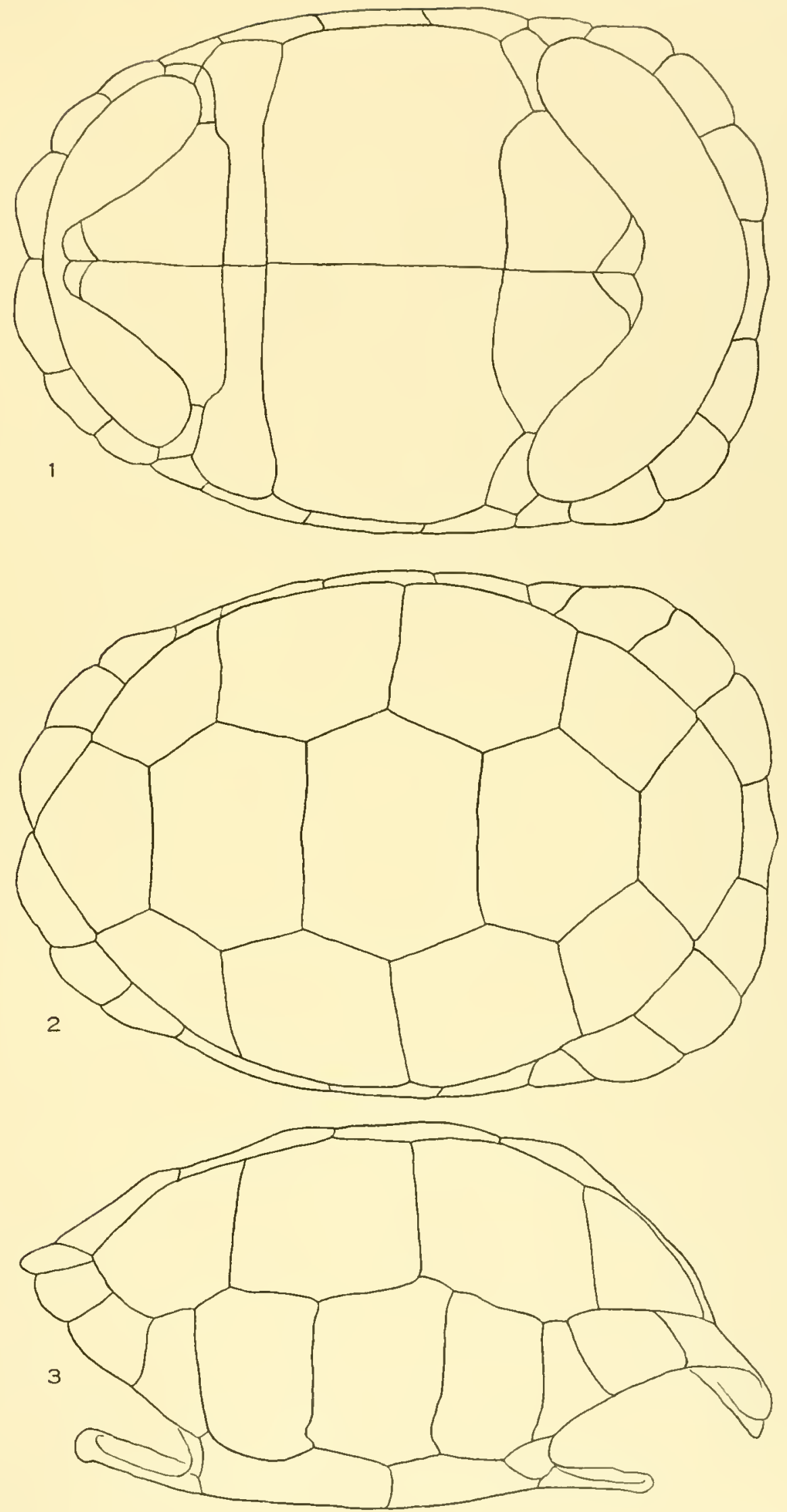

PLATE 4. 
PLA'T' 4.

'T'estudo mackophys Garman, 1917.

Page 273

1 ventral, 2 dorsal, 3 lateral.

From Günther, 1877, Gigantir tortoises, Plate 34, 35, fig. A. (T. microphyes Günther, 1877, nec 1875).

British Museum, СотrPE. North Isabela (Albemarle). Adult male. Length $33 \frac{1}{2}$ inches. Weight 240 pounds. 

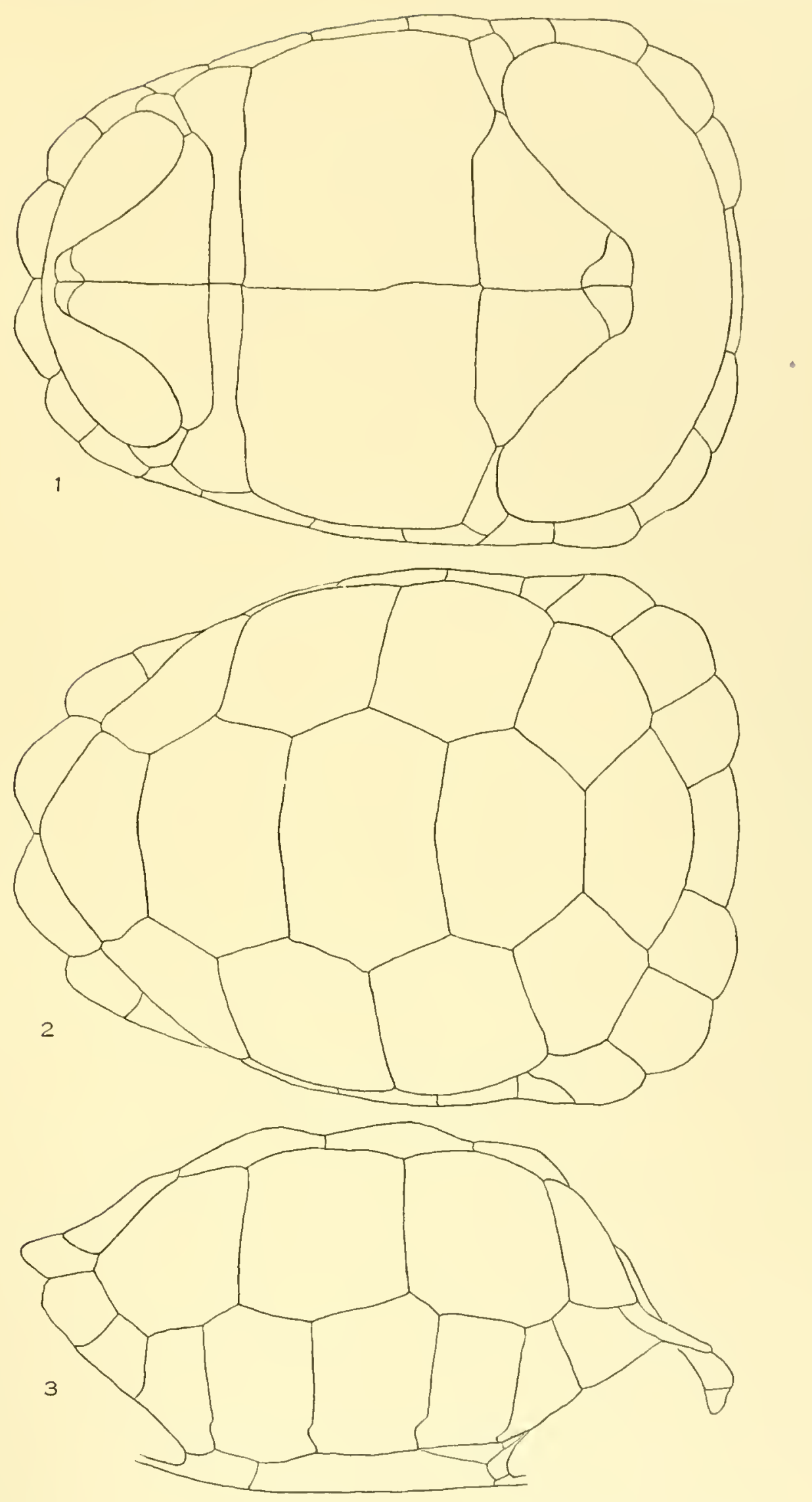

PLATE 5. 
PIAATE 5.

1 ventral, 2 dorsal, 3 lateral.

From Günther, 1s77, Gigantic tortoises, Plate 36, 35, fig. B. (T'. microphyes Günther 1S77, nec 1S75). British Museum, Cotrps. North Isaljela (Albemarle). Adult female. Length 27 inches. 

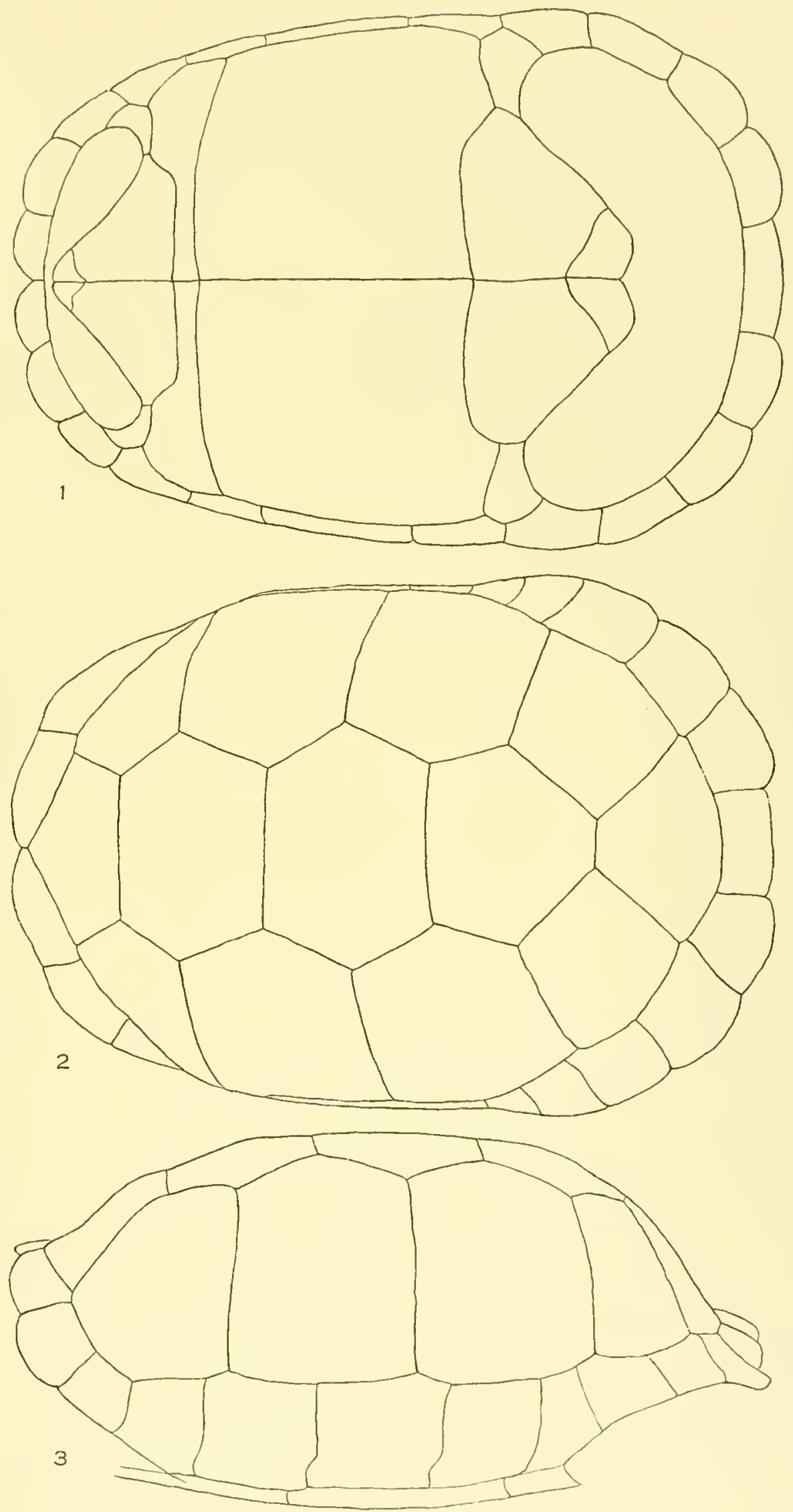

PLATE 6. 
PLATE 6.

Testudo vicina Günther, 1875.

Page 274

1 lateral, 2 dorsal, 3 ventral.

M. C. Z. 4482. Santa Maria (Charles) Hassler Exped. Length $14 \frac{1}{2}$ inches. 


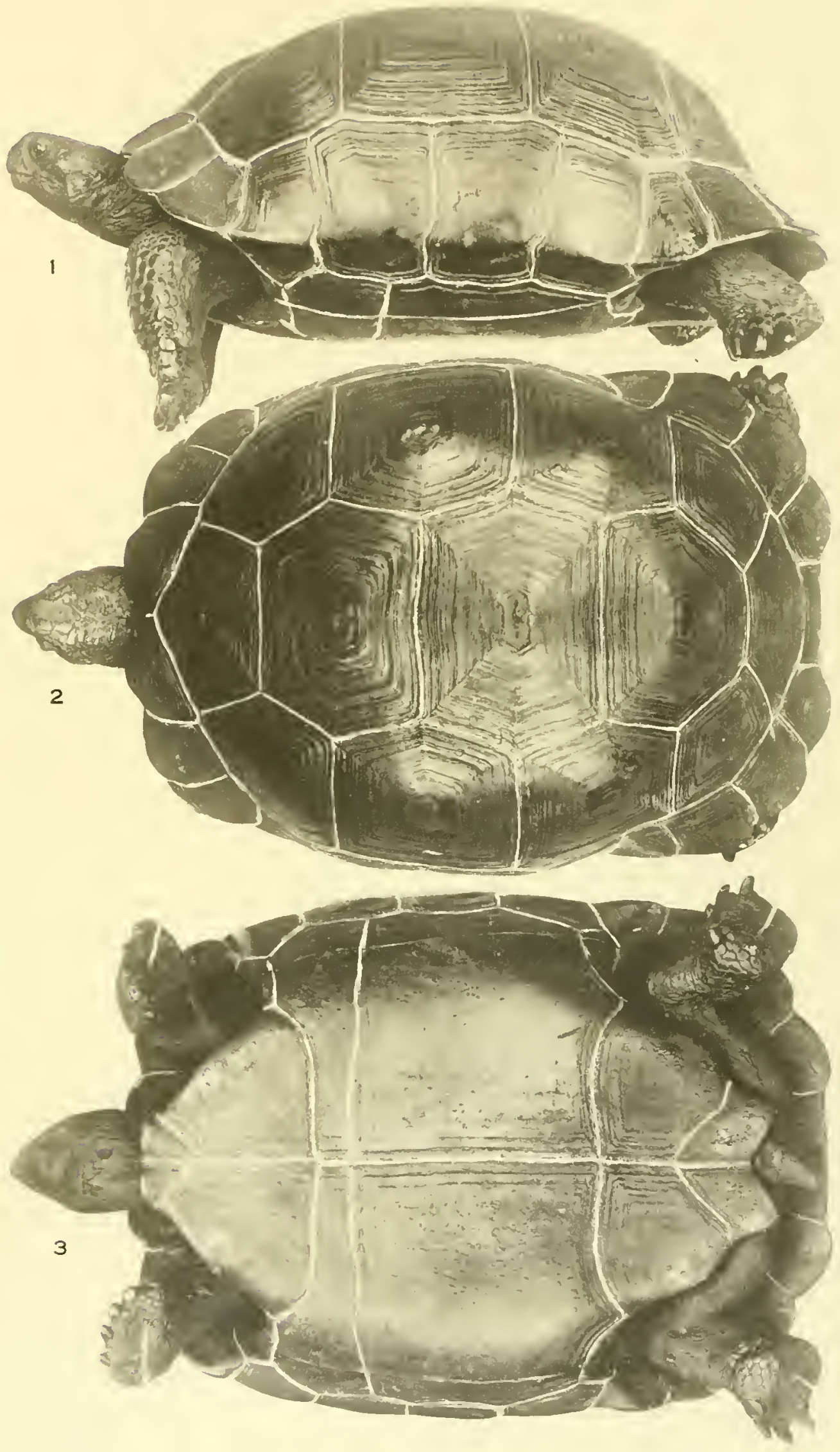



PLATE 7. 
PLATE 7.

Testedo vicriva Giünther, 1875.

1 ventral, 2 dorsal, 3 lateral.

From Günther, 1875, Philos. Trans. Royal soc. London, 165, Plate 35, fig. A.

British Museum. Type. Male. Length 33 inches. 
MEM. MUS. COMP. ZOÖL.

GALAPAGOS TORTOISES PLATE 7
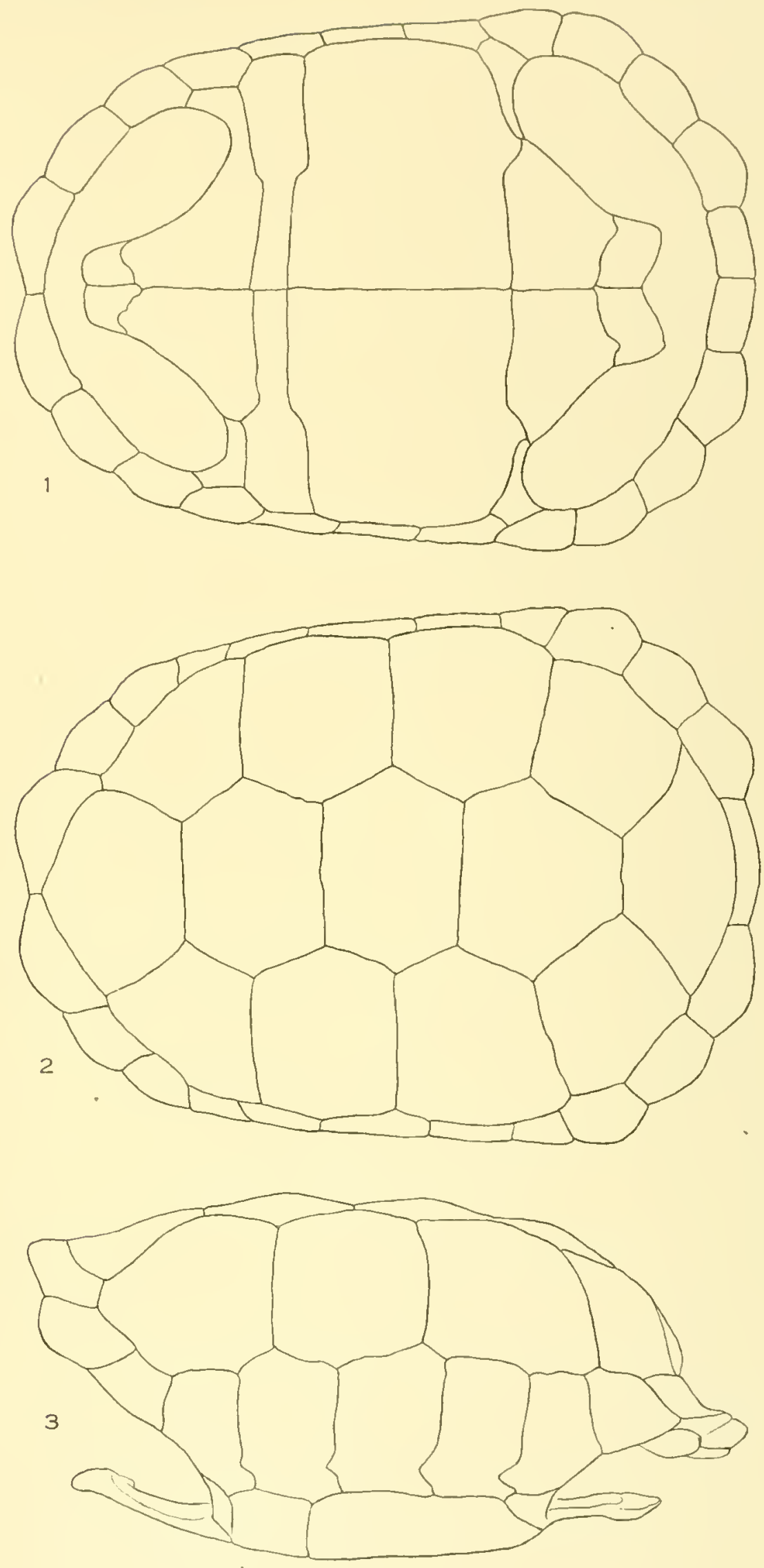

PLATE 8. 
PLATE 8.

Testudo nigita Duméril et Bibron, 1835.

Page 276

1 ventral, 2 dorsal, 3 lateral.

From Günther, 1875, Philos. Trans. Royal Soc. London, 165, Plate 35, fig. C.

Royal College of Surgeons, London. Length, 22 inches. 

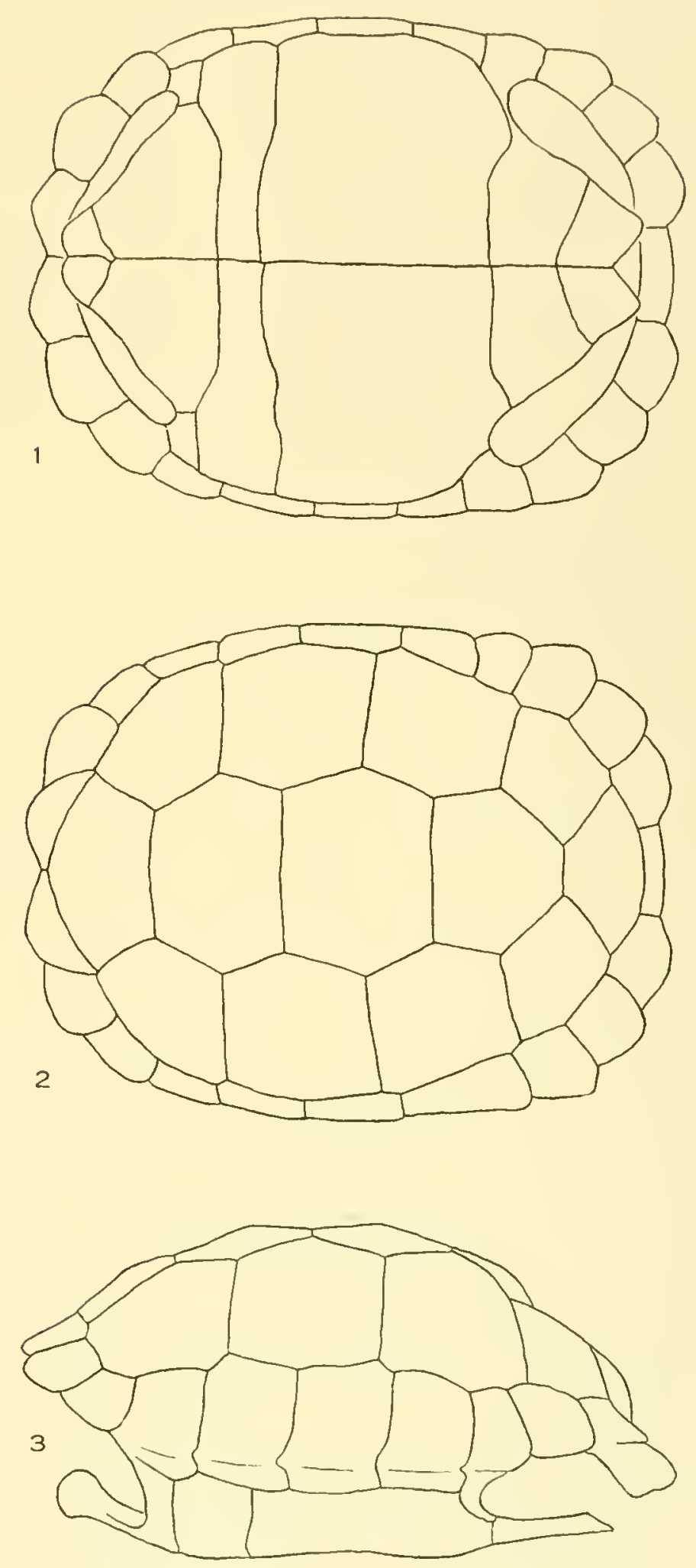


PLATE 9.

Testudo nigrita Duméril et Bibron, 1835.

1 posterior, 2 lateral, 3 dorsal.

From Günther, 1875, Philos. Trans. Royal Soc. London, 165, Plate 33, fig. B.

Royal College of Surgeons, London. Length 41 inches. 
MEM. MUS. COMP. ZOÖL.

GALAPAGOS TORTOISES PLATE 9
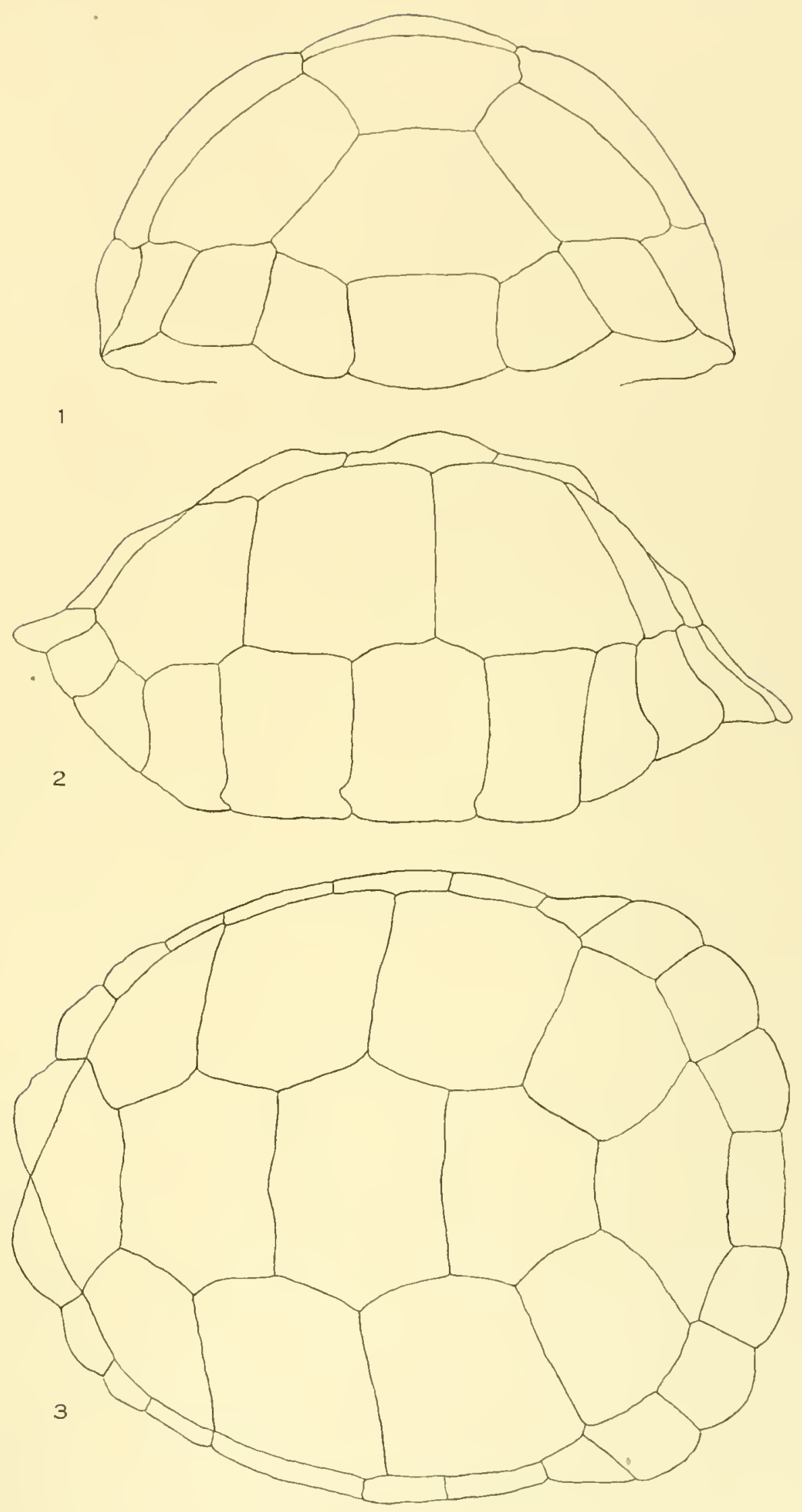


PLATE 10.

Testudo nigrita Duméril et Bibron, 1835.

Page 276

1 dorsal, 2 lateral, 3 ventral.

M. C. Z. 12049. Santa Maria (Charles). Hassler Exped. Length 11 inches. 


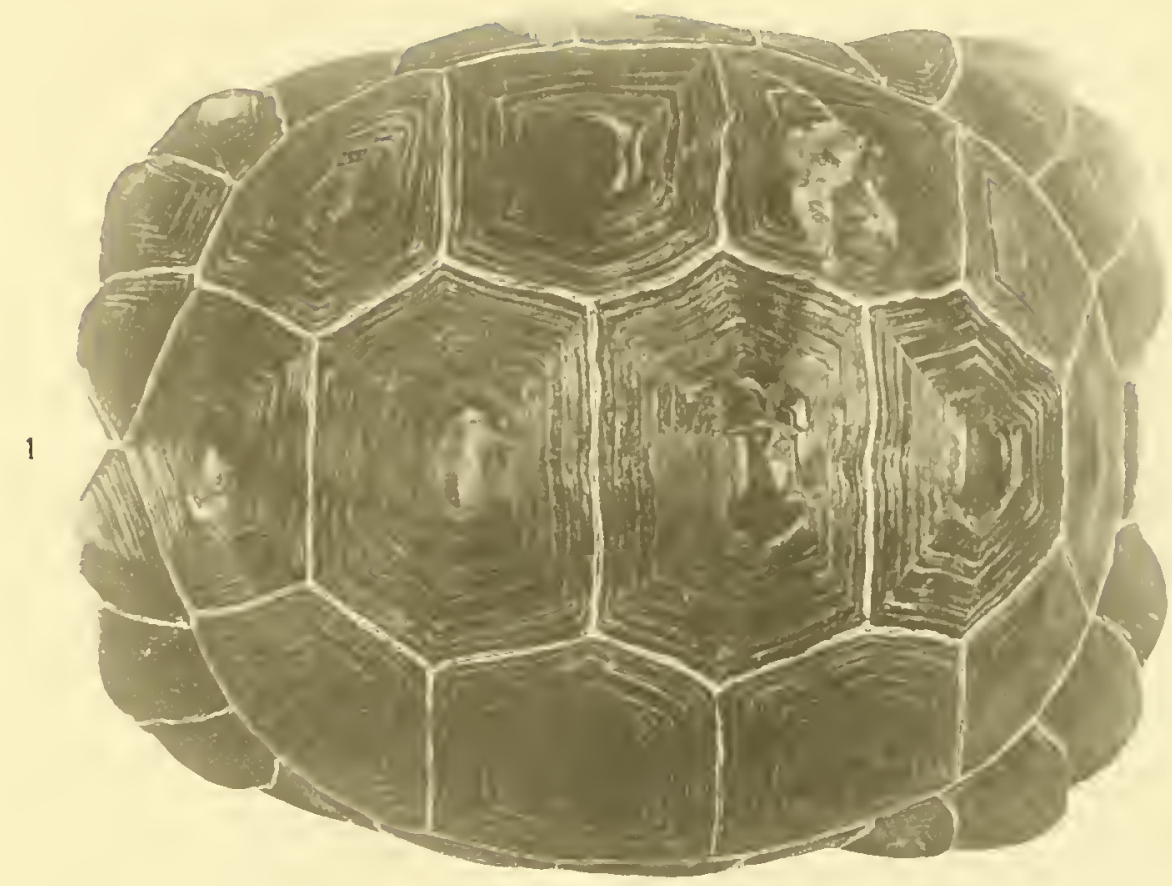

2

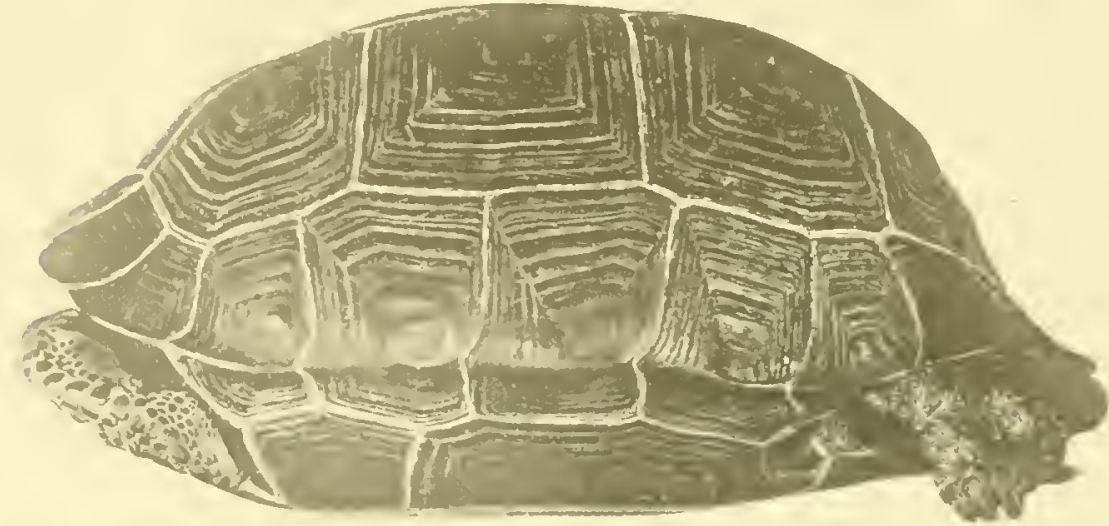

3

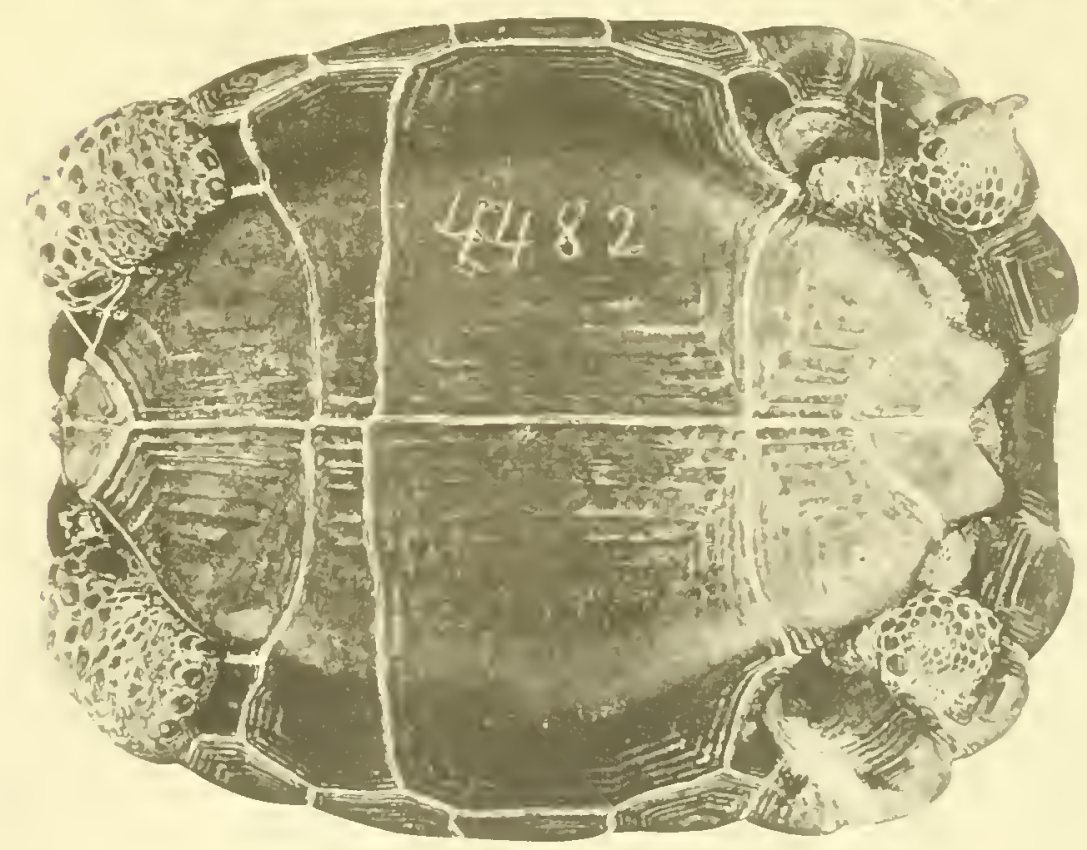



PLATE 11. 
PLATE 11.

Testudo Microphyes Günther, 1875.

1 ventral, 2 dorsal, 3 lateral.

From Günther, 1875, Philos. Trans. Royal Soc. London, 165, Plate 36.

Royal Inst. Liverpool. TYre. Española (Hood). luength, $22 \frac{1}{2}$ inches. 

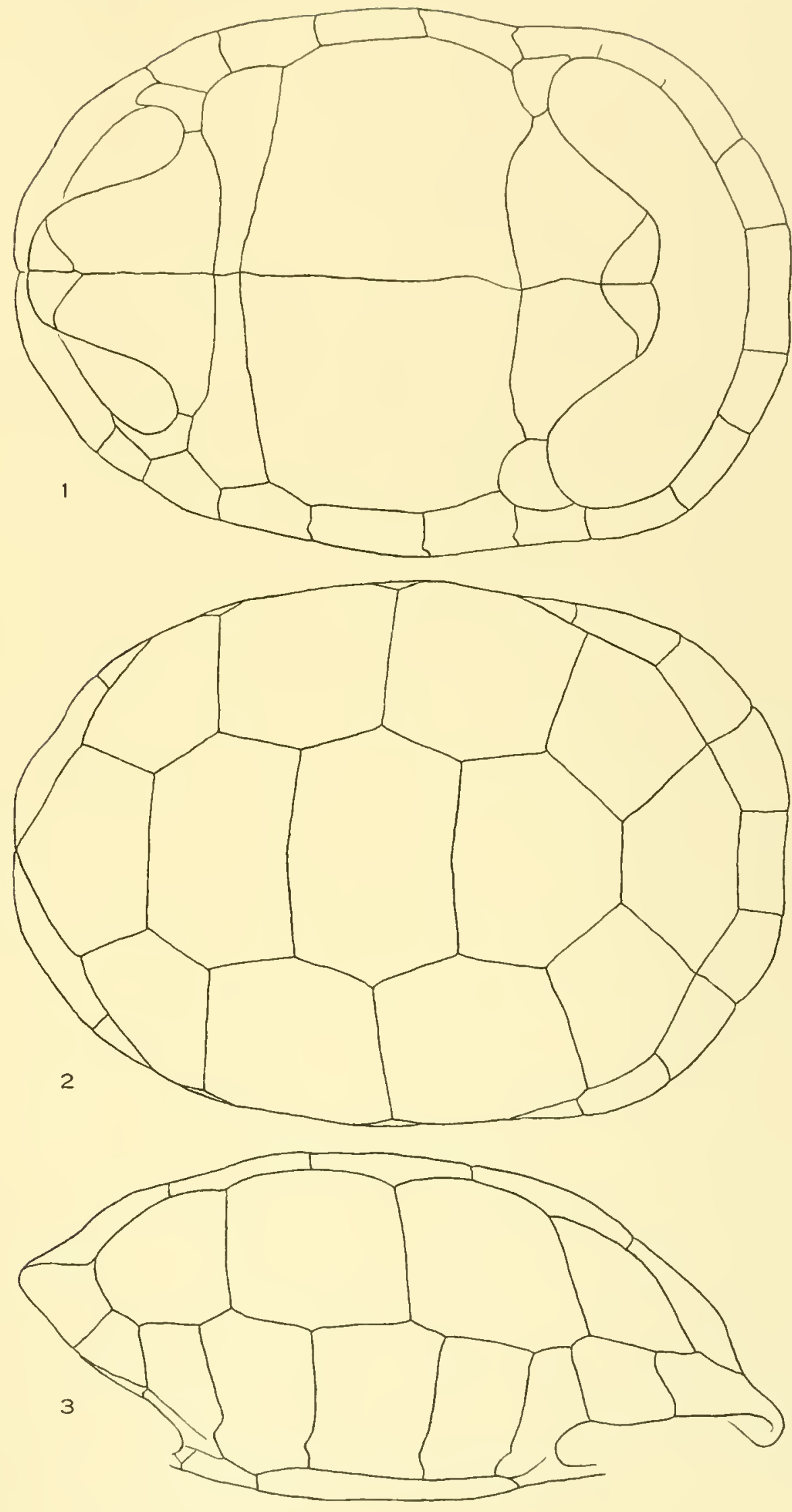

PLATE 12 
PI,ATE 12.

Testudo Microphyes Günther, 1875.

Page 280

1 dorsal, 2 lateral, 3 ventral.

M. C. Z. 11067. Villamiel, Southern Isabela (Albemarle). California Academy of Sciences. Length $2.5 \frac{1}{8}$ inches. 

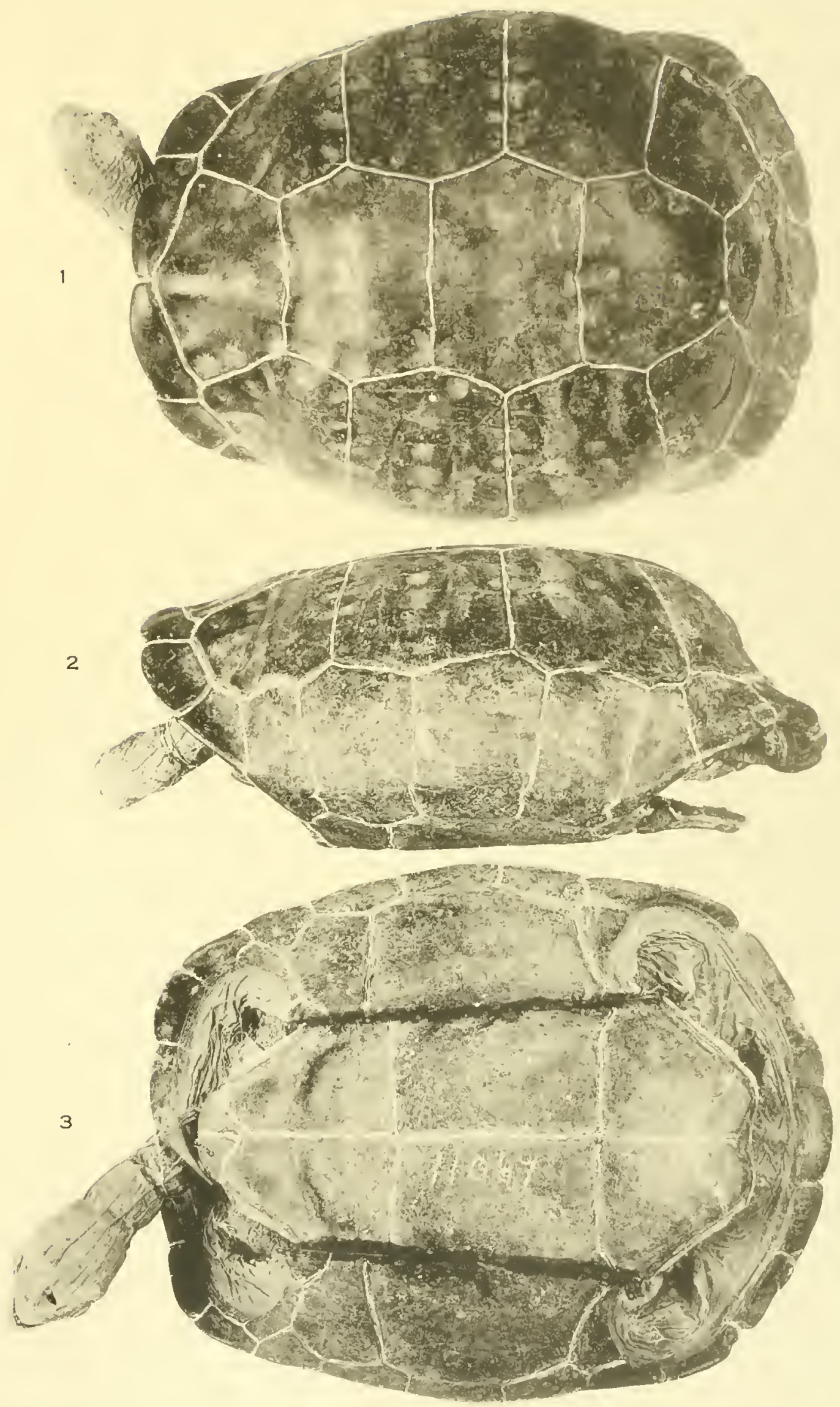

PLATE 13. 
PLA'TE 13.

Testude Mirrophyes Günther, 1875.

Page 280

1 lateral, 2 ventral, 3 dorsal.

M. C. Y. 11055 . Southern Jsahela (Alhemarle). F. B. Webster. Length 42 inehes. 


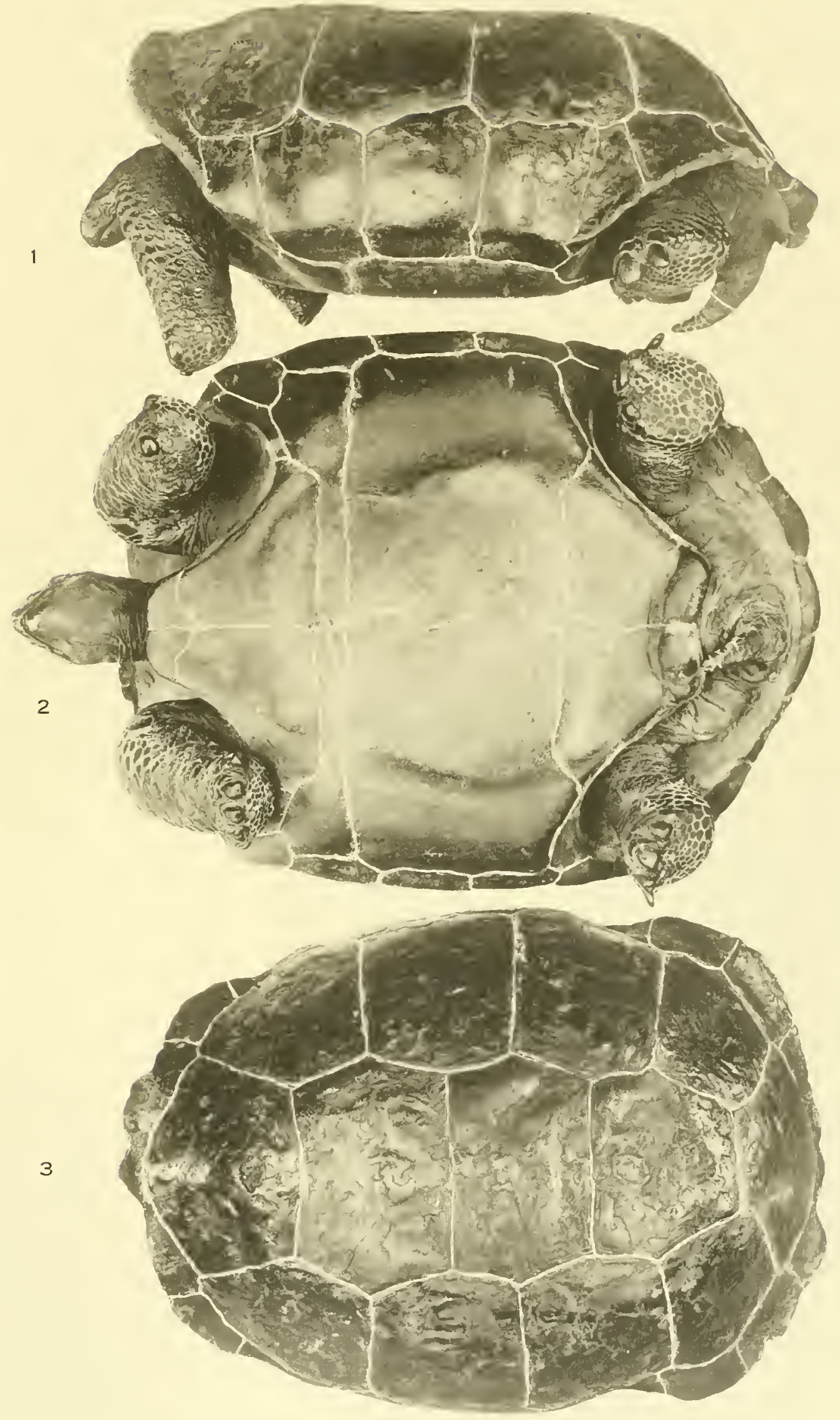



PLATE 14. 


\section{PLATE 14}

'Testudo Microphyes Günther, 1875.

Page 280

1 dorsal, 2 lateral, 3 ventral.

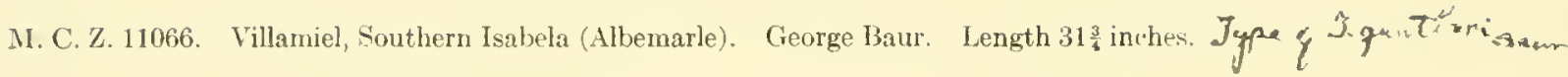




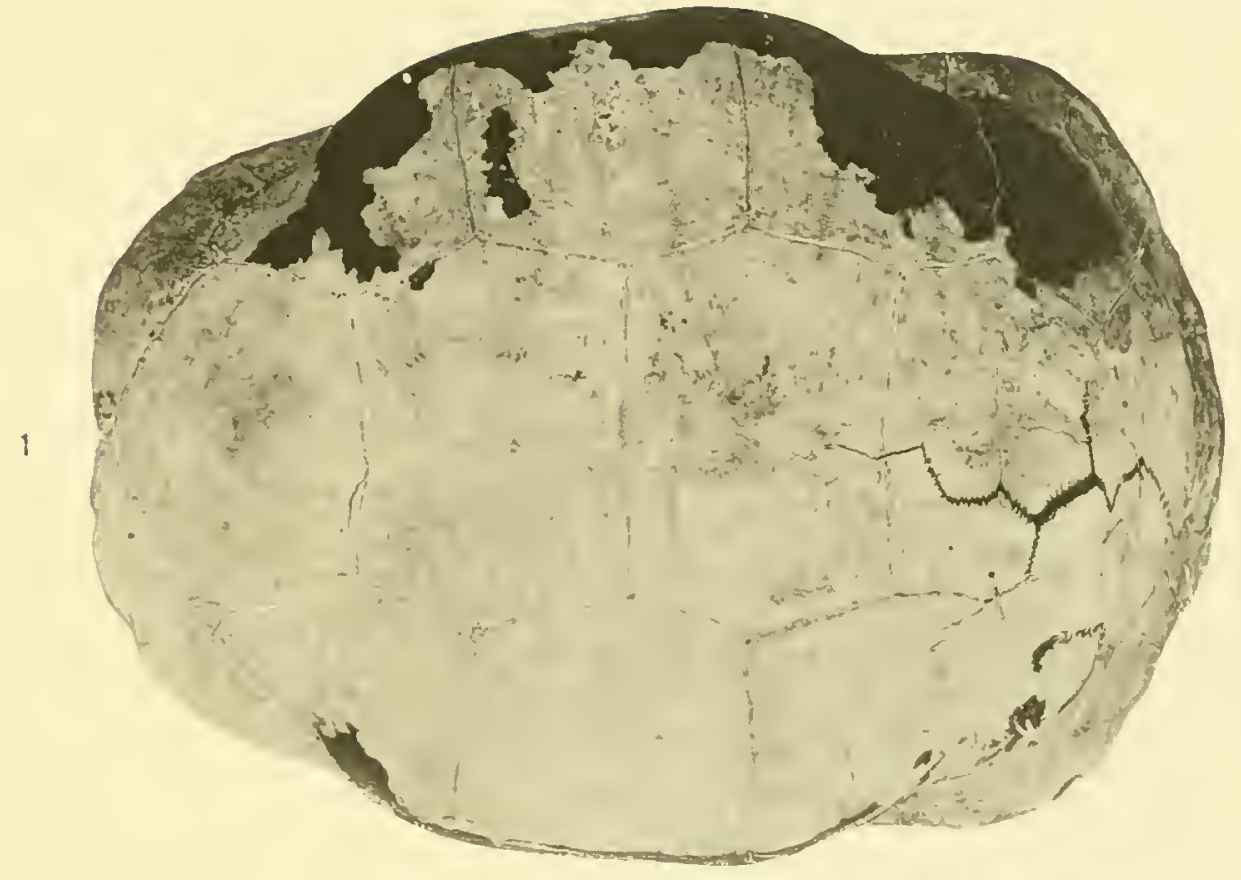

2

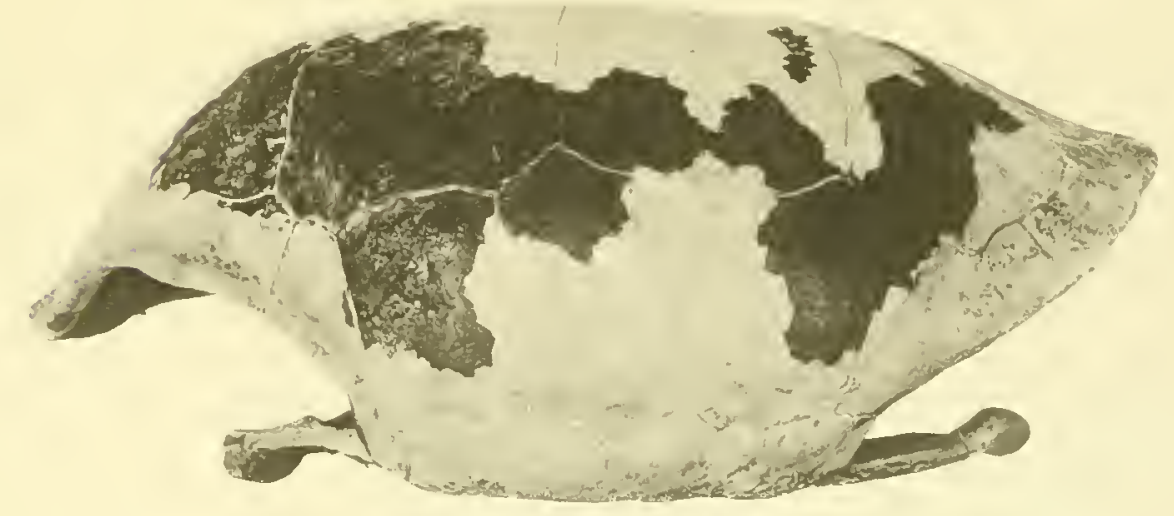

3

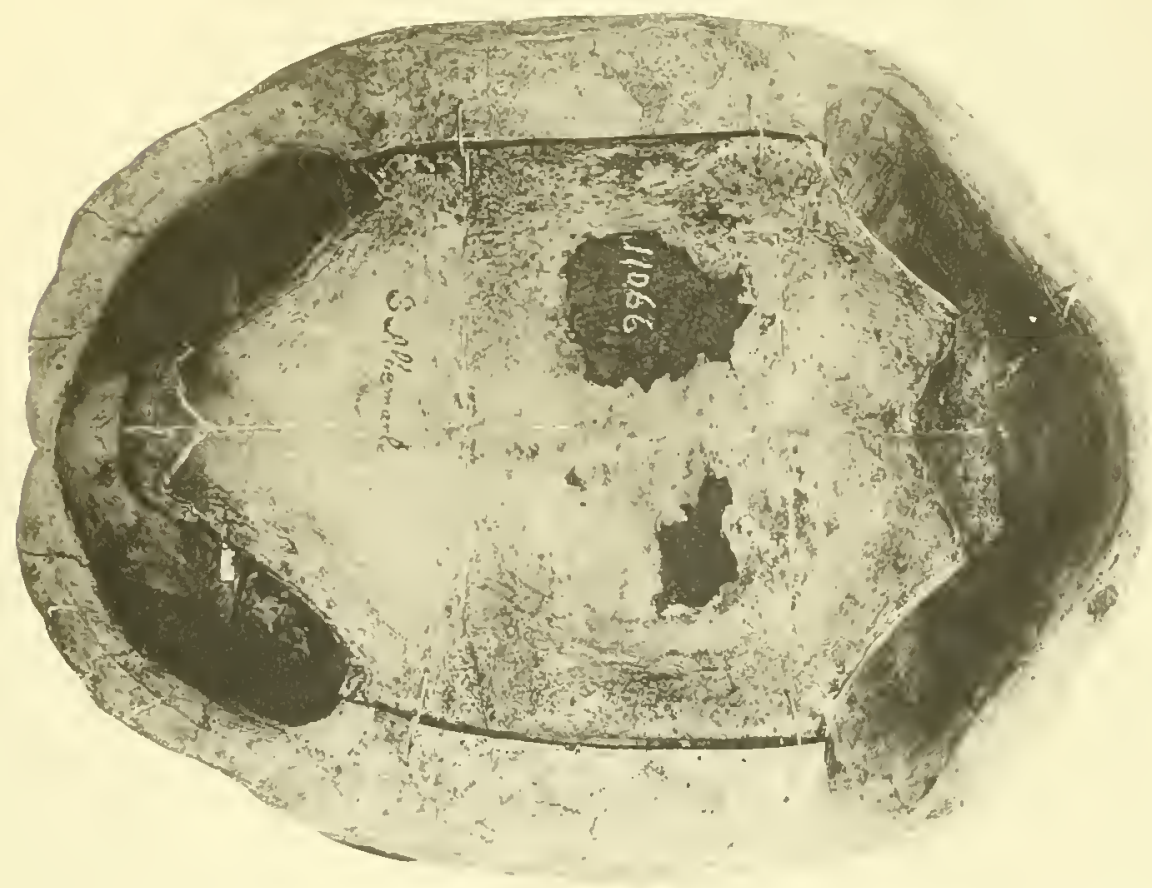



PIsATE 15 
PIATE 16.

Testudo Microphyes Gïnther, 1875.

Page 2s0

1 lateral, 2 dorsal, 3 ventral.

From Günther, 1875, Philos. Trans. Royal Soe. London, 165, Plate 33, fig. I ( $T$. elephantopus Cuinther nee Harlan).

Tniversity Oxford Mnsenm. Length 31 inches. 
MEM. MUS, COMP. ZOÖL.

GALAPAGOS TORTOISES PLATE 15
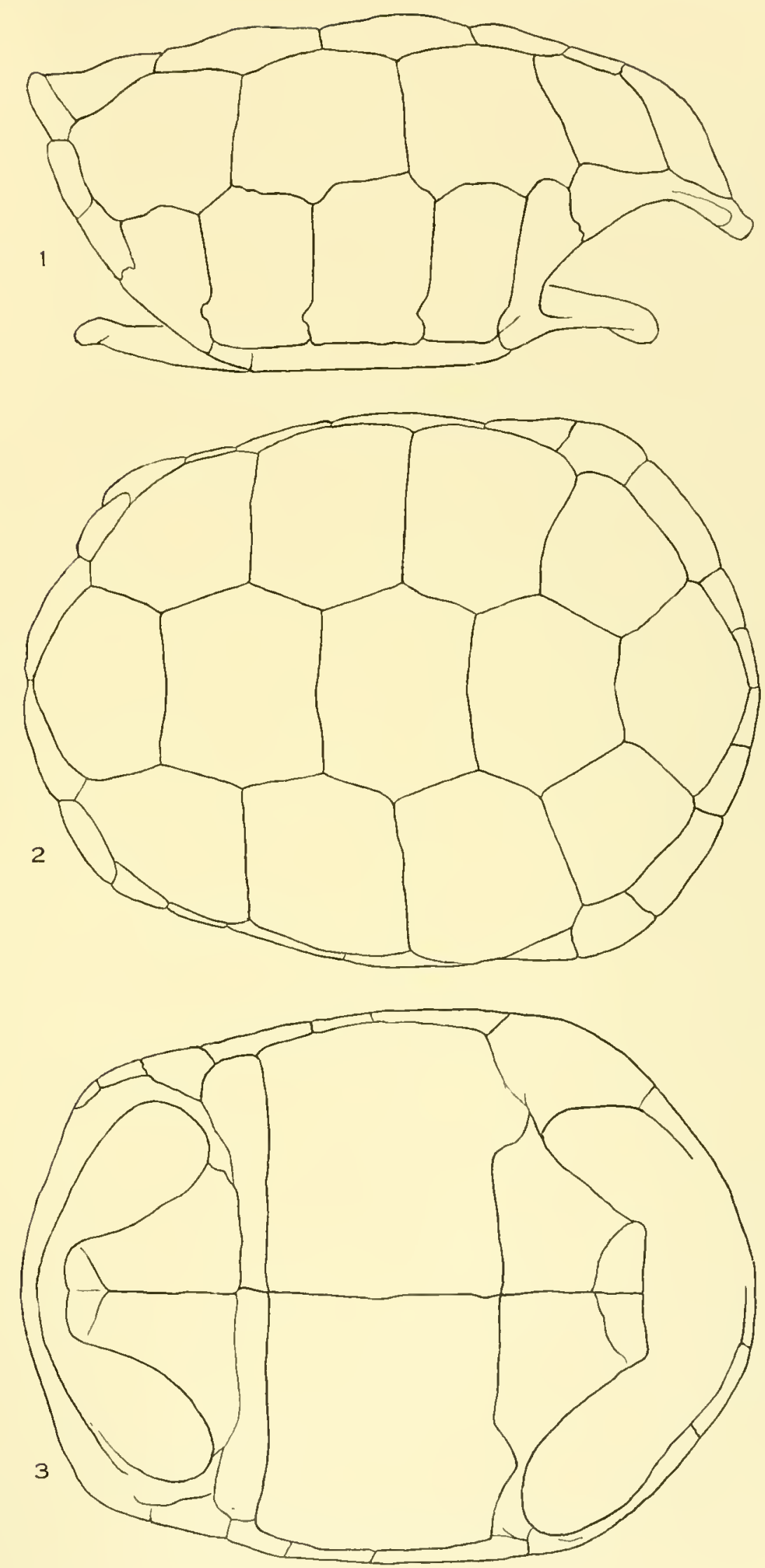

PLATE 16. 
PLATE 16.

Testudo microphyes Günther, 1875 .

1 dorsal, 2 lateral, 3 ventral.

M. C. Z. 11065. Villamiel, Southern Isabela (Alhemarle) George Baur. Length $37 \frac{1}{2}$ inches. 


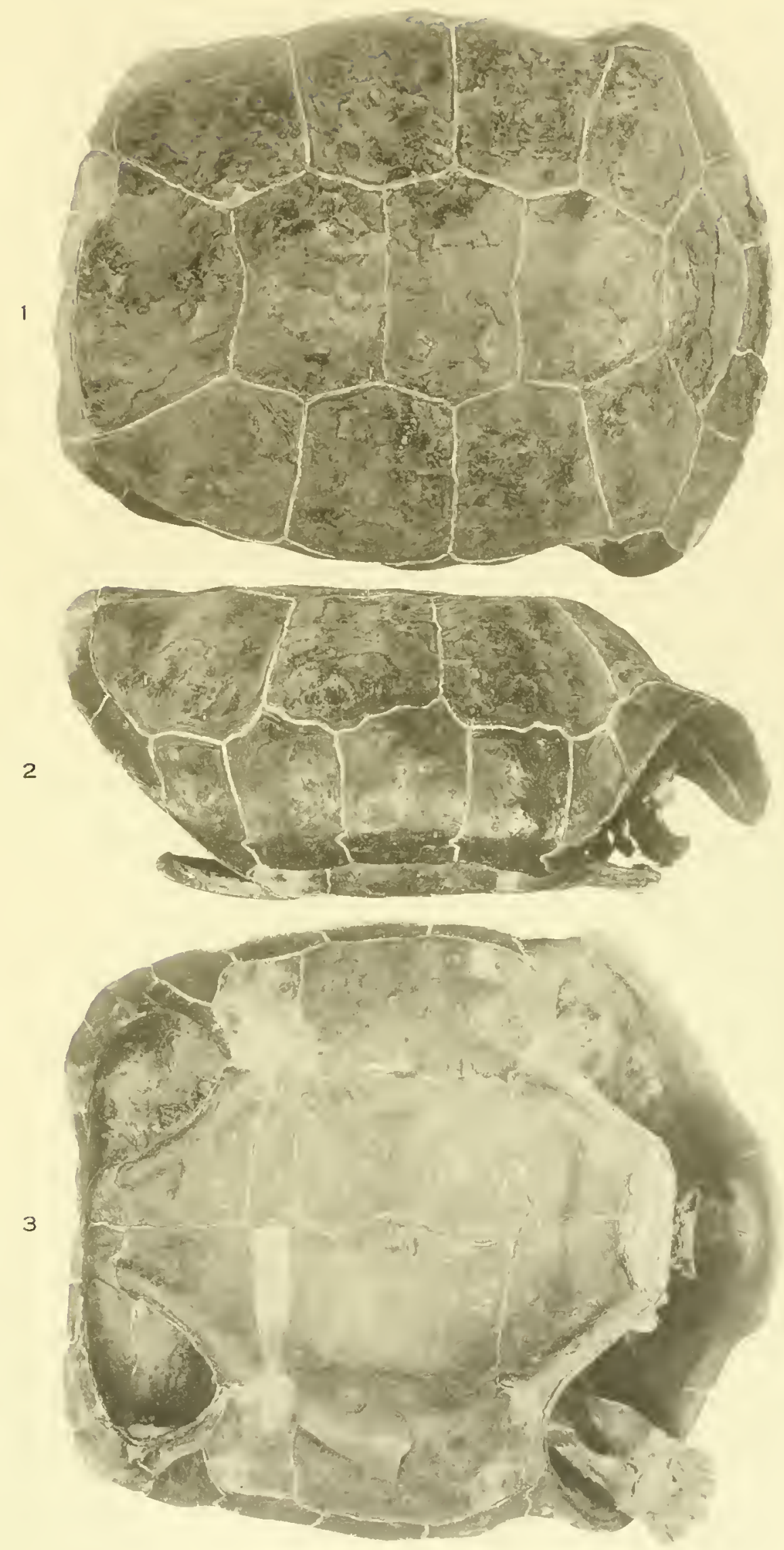



PLATE 1 
PLATE 17.

Testudo Mrcrophyes Günther, 1875.

Page 280

1 dorsal, 2 lateral, 3 ventral.

M. C. Z. 4479. Santa Maria (Charles). Hassler Exped. Length $15 \frac{1}{4}$ inches. 


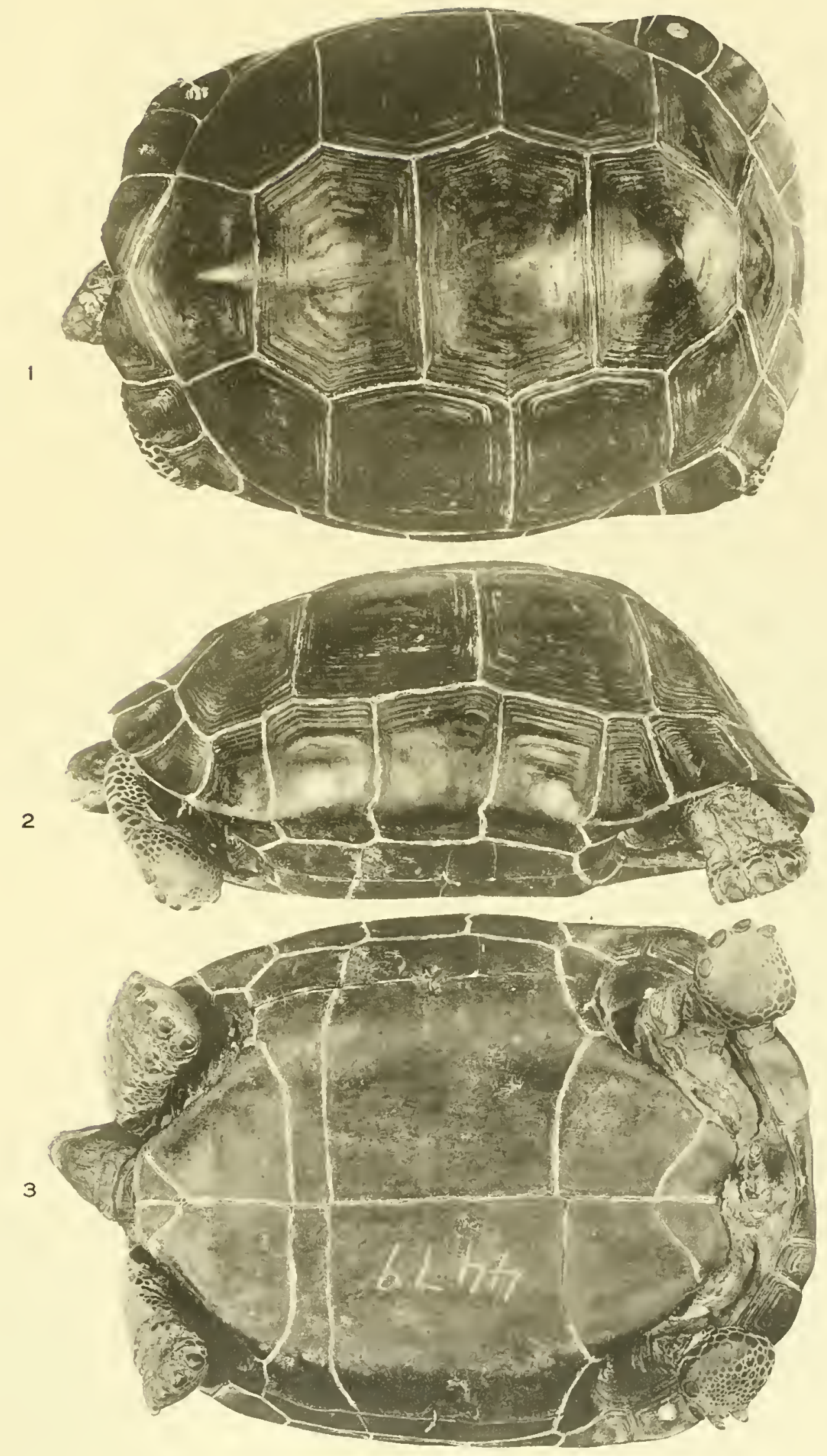



PLATE 18 
PLATE 18.

Testudo Microphyes Günther, 1575.

Page 2S0

1 ventral, 2 dorsal, 3 lateral.

M. C. Z. 4479. Santa Maria (Charles). Hassler Exped. Length $15^{1}$ inches. 
MEM. MUS. COMP. ZOOL.

GALAPAGOS TORTOISES PLATE IB
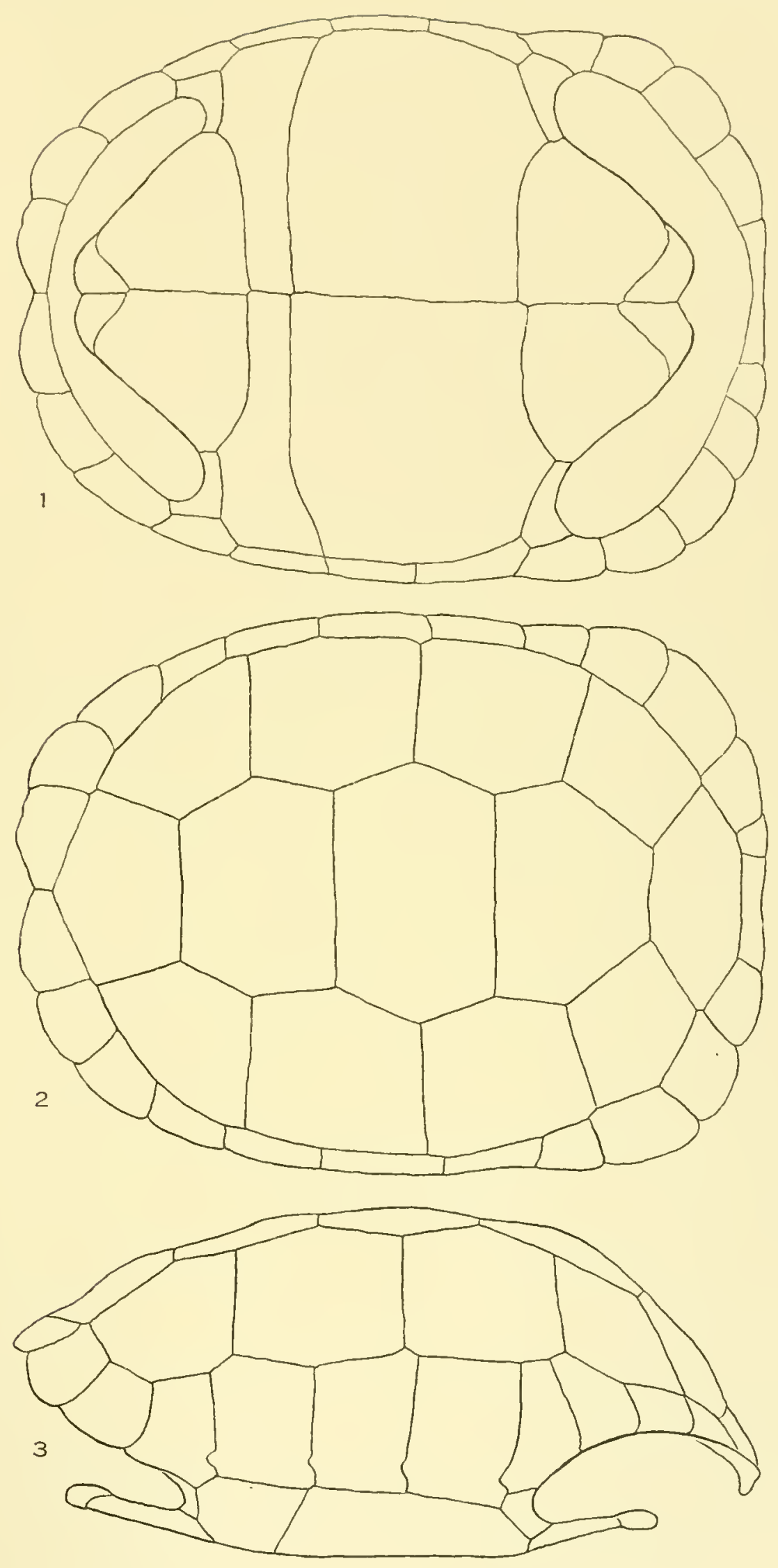

PLATE 19 


\section{PLATE 19.}

Testudo microphyes Günther, 1875.

1 dorsal, 2 lateral, 3 ventral.

M. C. Z. 4476. Santa Maria (Charles), Louis Agassiz. Length $15 \frac{1}{2}$ inches. 

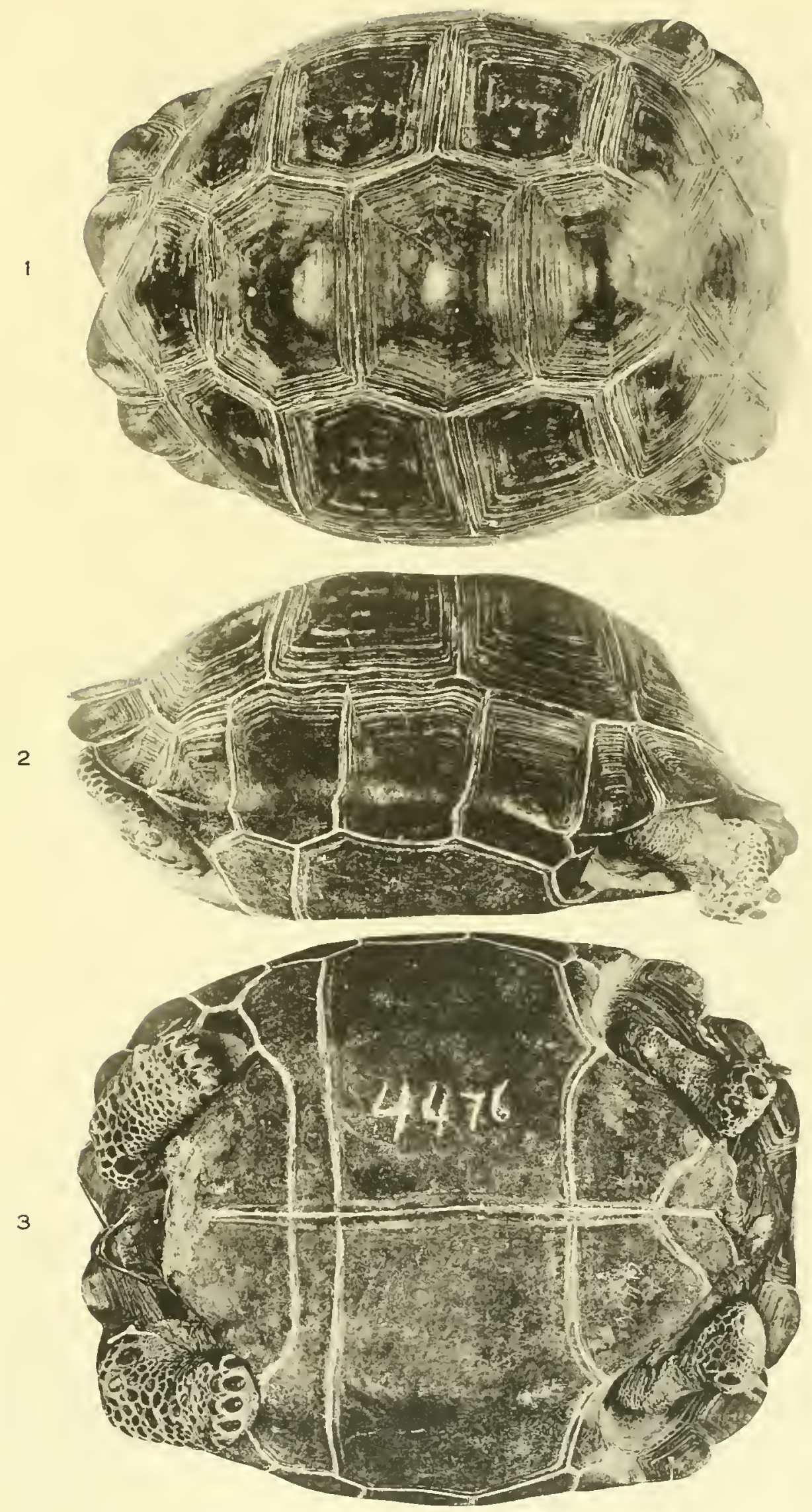

PLATE 20. 
PLATE 20.

Testudo microphyes Günther, 1875.

Page 280

1 dorsal, 2 lateral, 3 ventral.

M. C. Z. 11071 . C. F. Winslow. Length $23 \frac{5}{8}$ inches. 


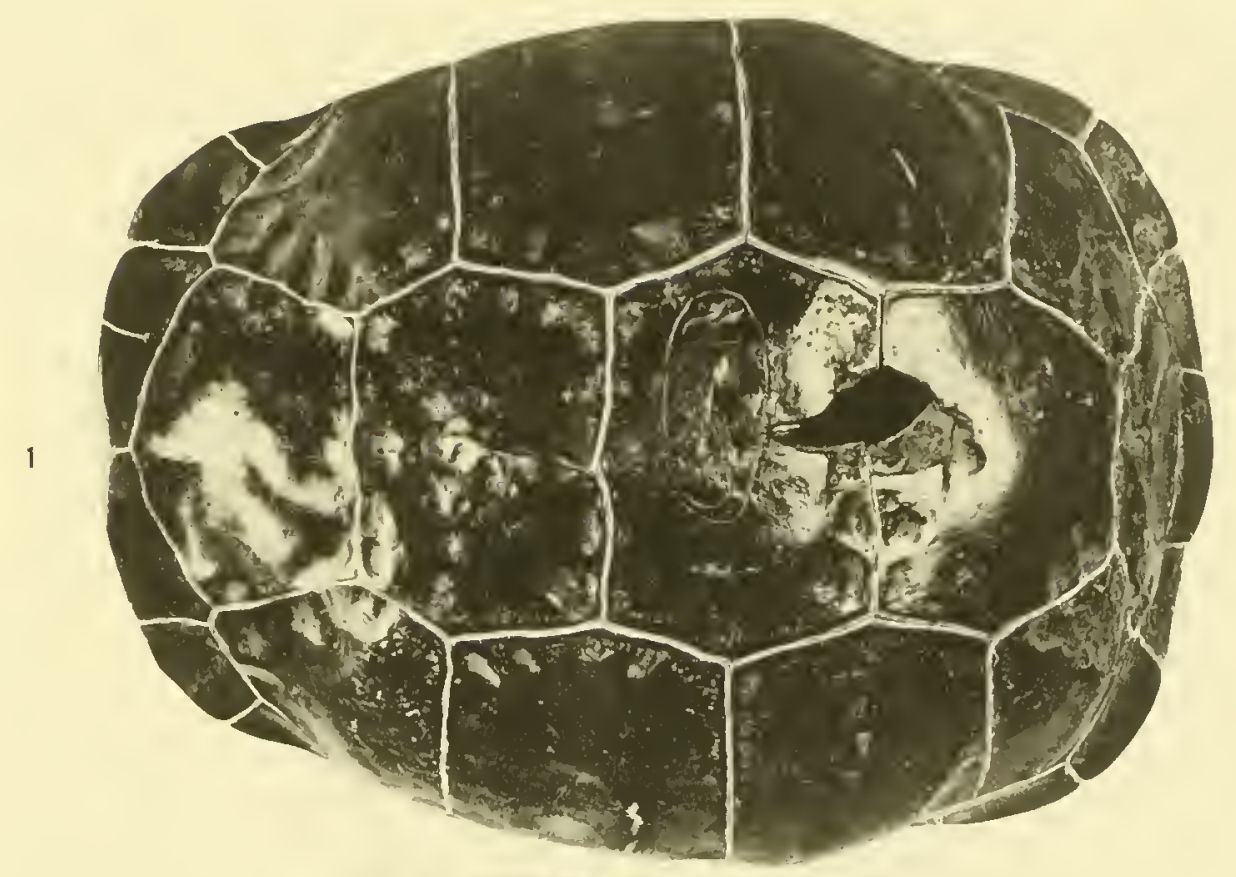

2
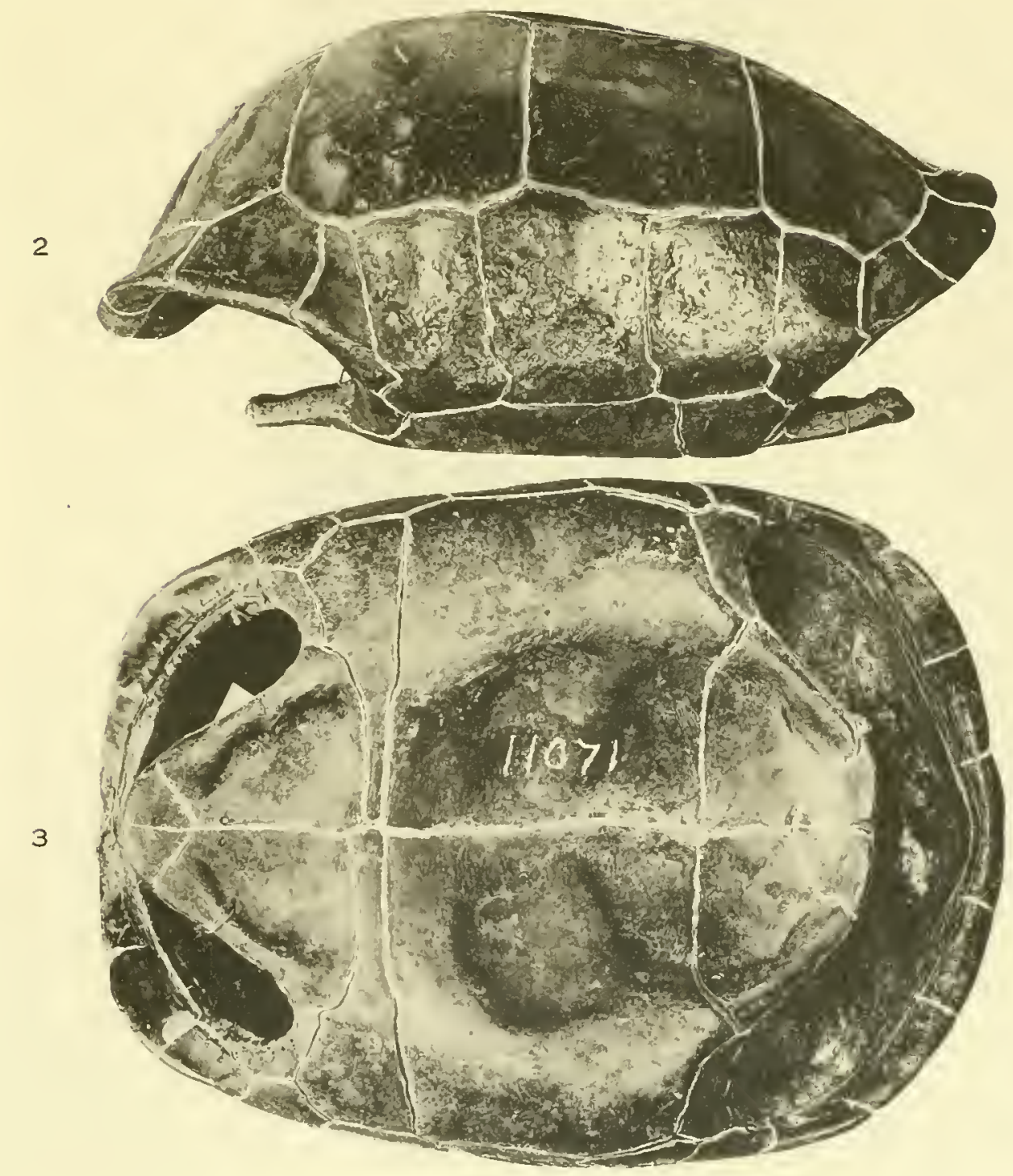

PLATE 21 
PLATE 21.

Testudo runosa Garman, 1916.

Page 283

1 dorsal, 2 lateral, 3 ventral

M. C. \%. 11675. TYPE. Boston Society of Natural History. Length $25 \frac{3}{8}$ inches. Jype. 

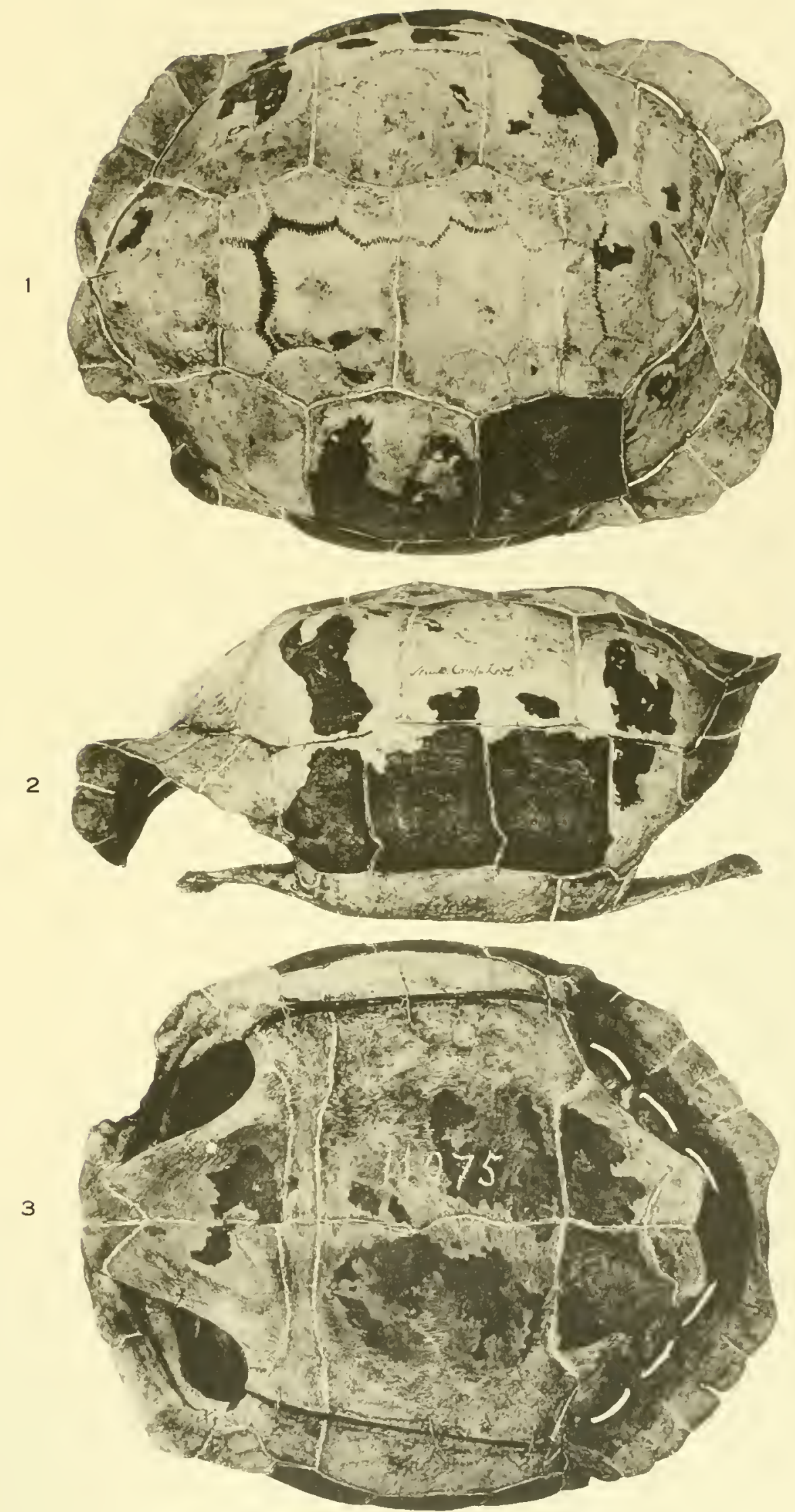

PLATE 22. 
PLATE 22.

Testudo typica Garman, 1916.

Page 28.5

1 dorsal, 2 lateral, 3 ventral.

M. C. Z. 11072. TYPe. Boston Soriety of Natural History. Length 24 inches. 


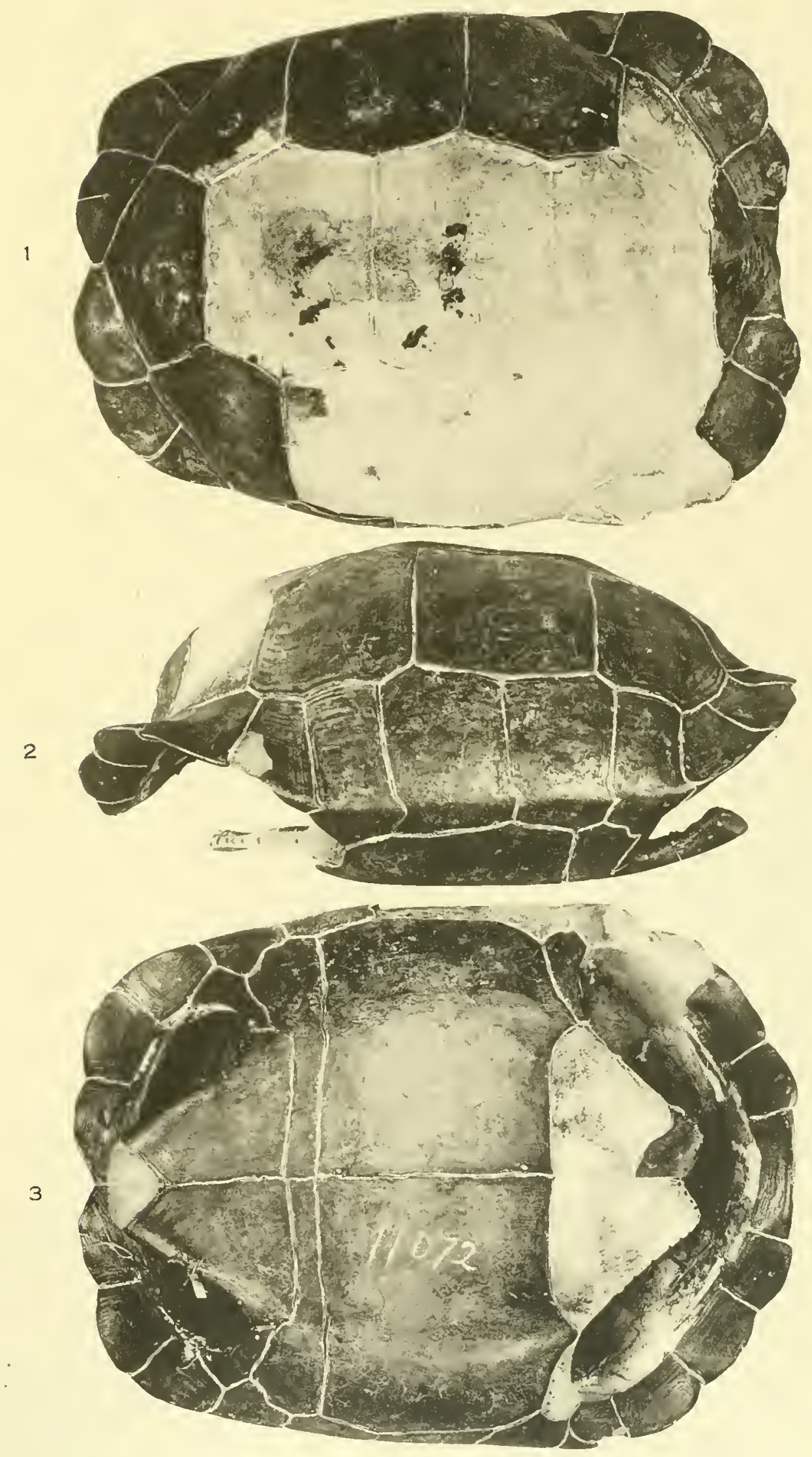



PIATE 23. 
PIATE 23.

Testudo nigra Quoy et Gaimard, 1824.

Page 286

1 lateral, 2 ventral, :3 lateral.

1 from Wiegmann, 1835, Nov, Acta Acad. Leop.-Carol., 17, Plate 13. Weight 125 pounds.

2, 3 from (quoy et raimard, 1824, Ioyage ITranie et Physicienne. Zool., Plate 40. Length 12 inches. 
MEM. MUS. COMP. ZOOL.

GALAPAGOS TORTOISES PLATE 23
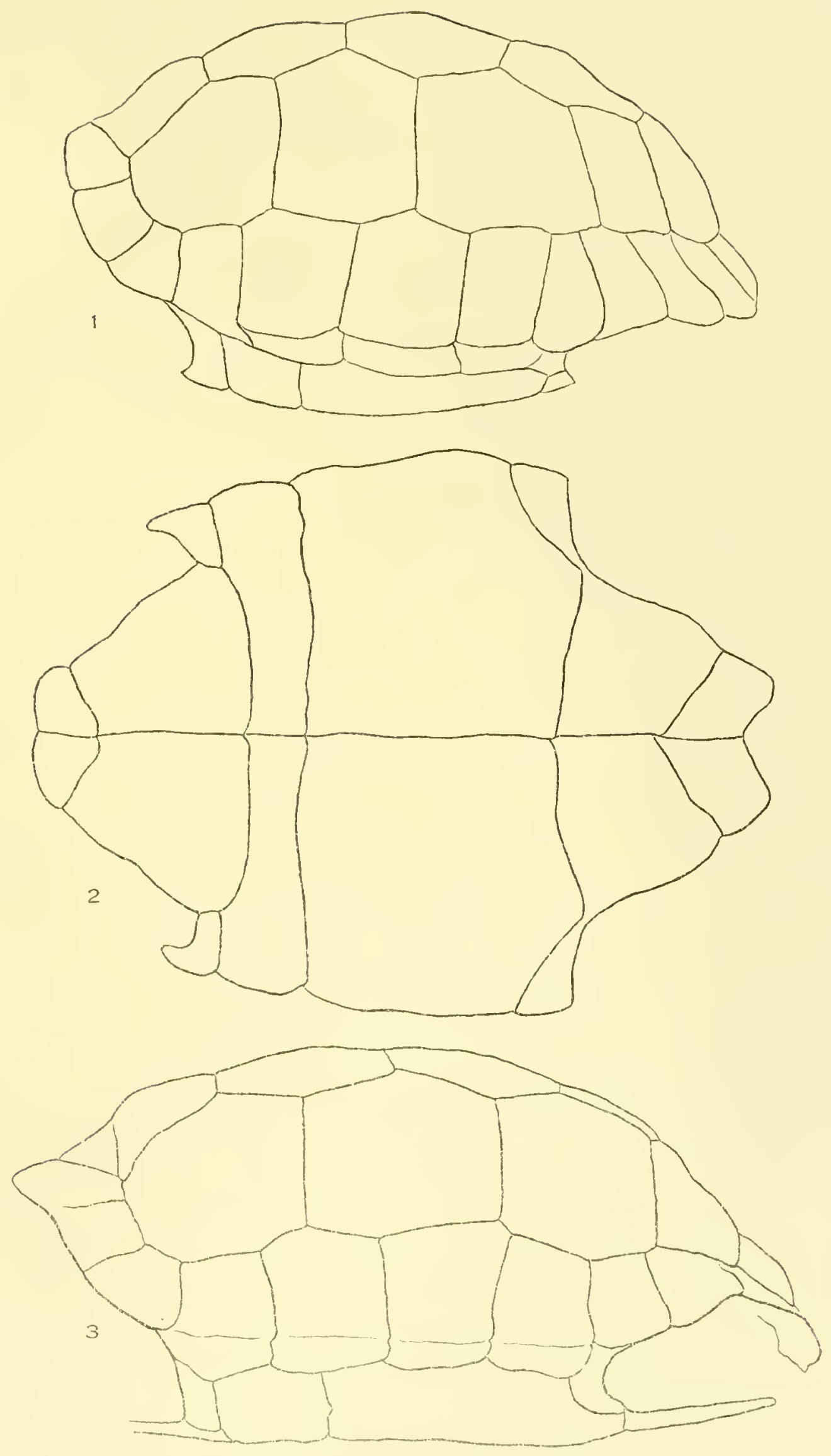

PLATE 24. 
PLATE 24.

Testudo Nigra Quoy et Gaimard, 1824.

Page 286

1 clorsal, 2 lateral, 3 ventral.

MI. C. Z. 4477. Santa Maria (Charles). Hassler Exped. Length $10 \frac{3}{4}$ inches. 


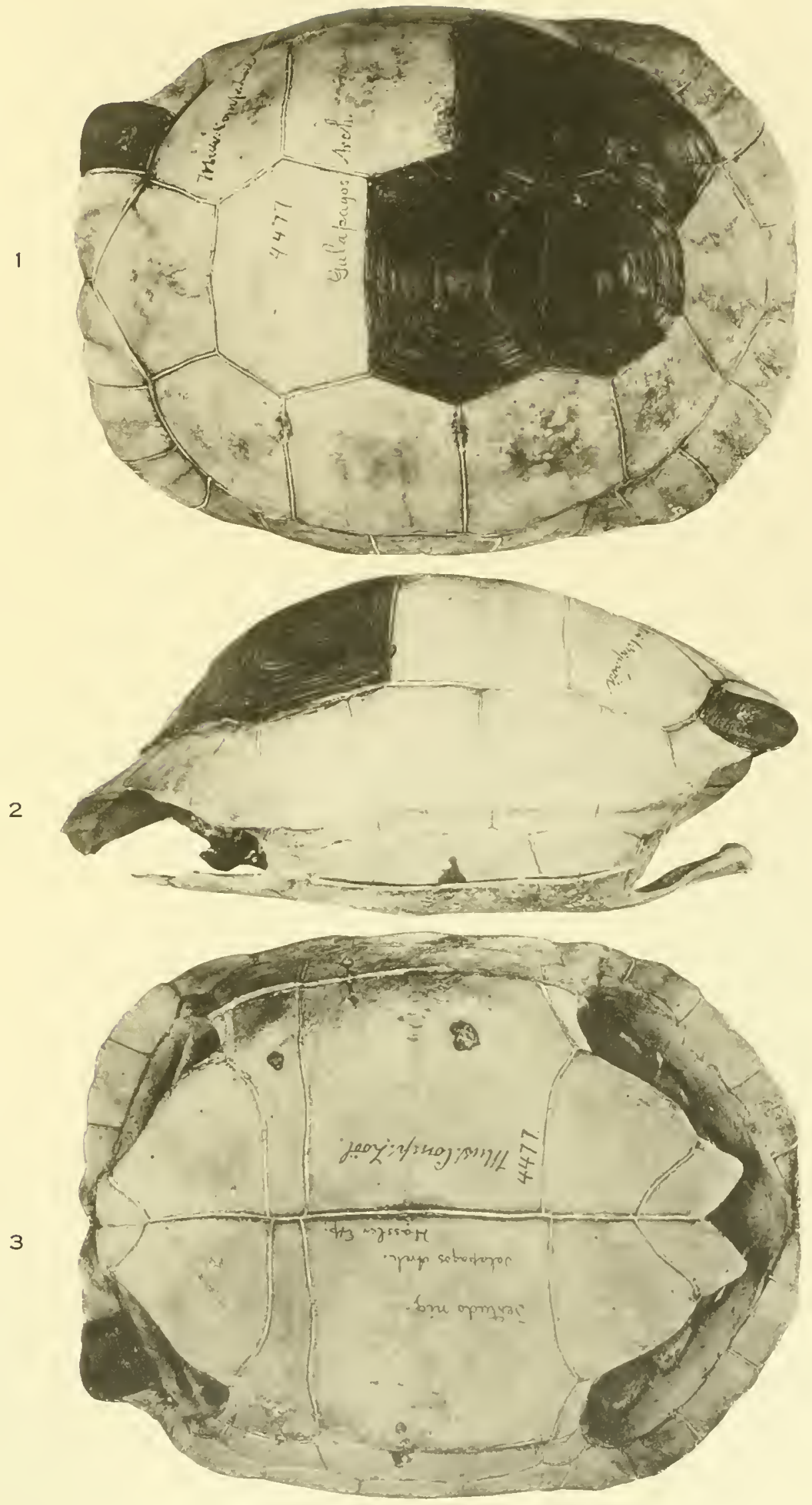




PLATE 26.

TESTUdo NIGRA Quoy et Gaimard, 1824 .

Page 286

1 dorsal, 2 lateral, 3 ventral.

M. C. Z. 4480. Santa Maria (Charles). Hassler Exped. Length 13 inches. 

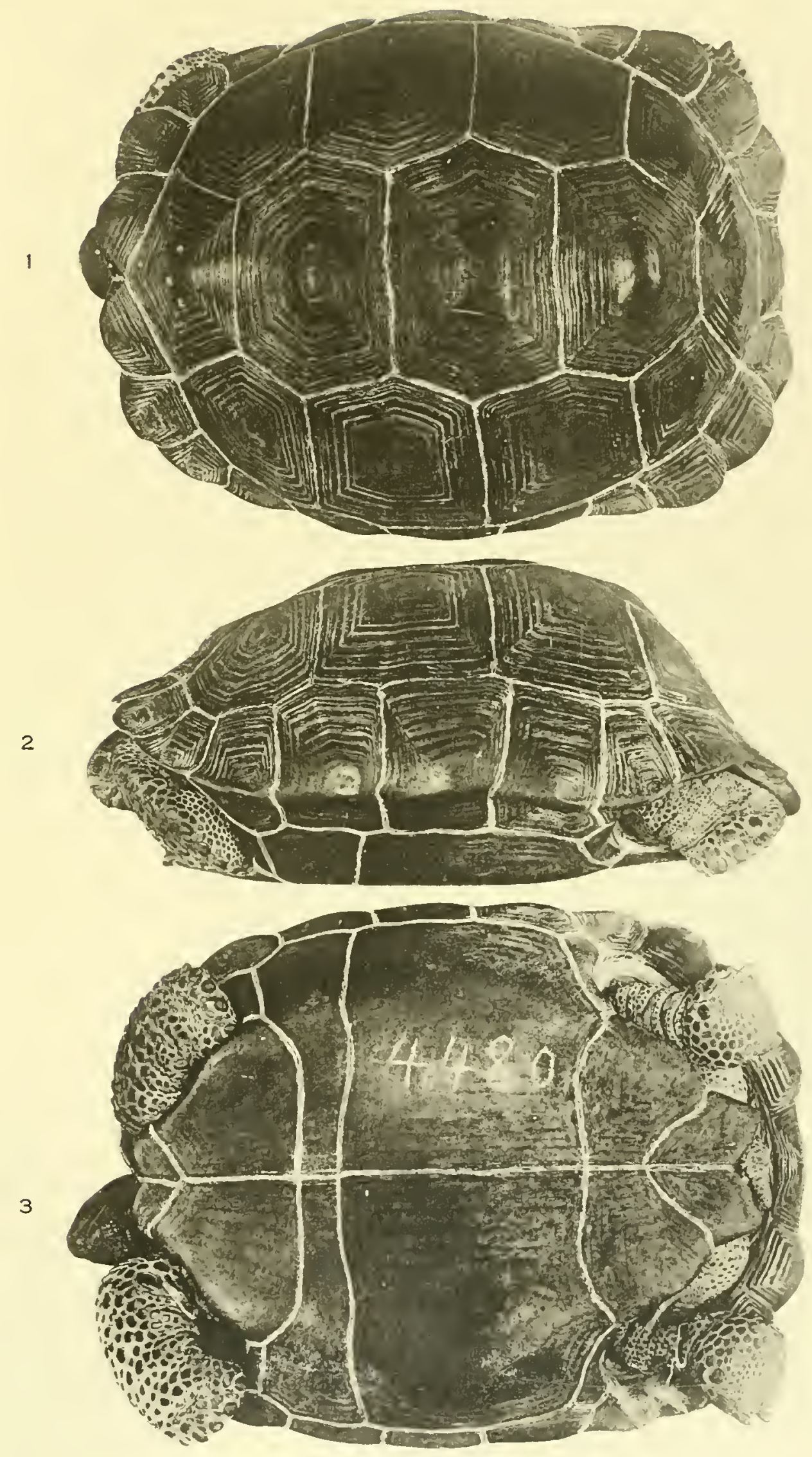


PLATE 26.

Testudo nigra Quoy et Gaimard, 1824.

Page 256

1 dorsal, 2 lateral, 3 ventral.

M. C. Z.447S. Santa Maria (Charles). Hassler Exped. Length 15 inches. 
1

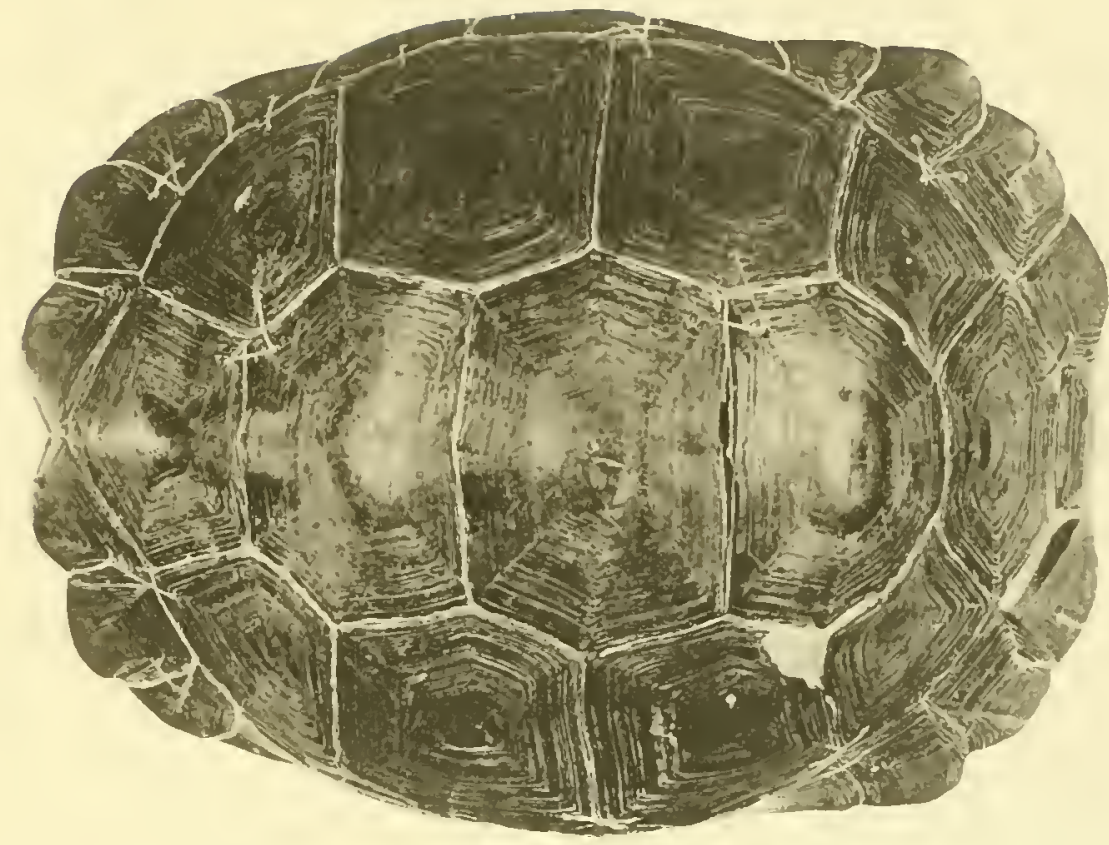

2

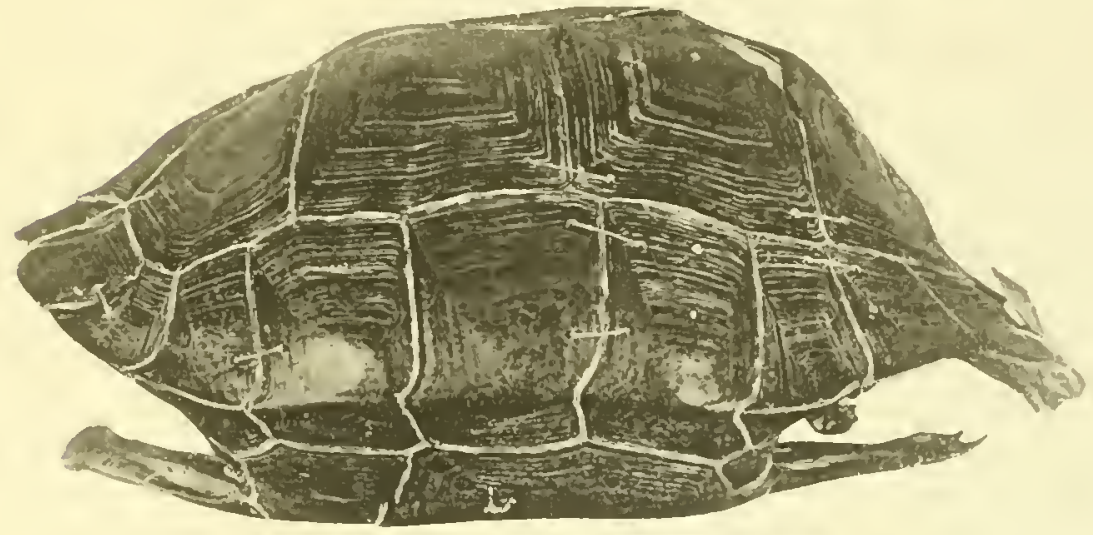

3

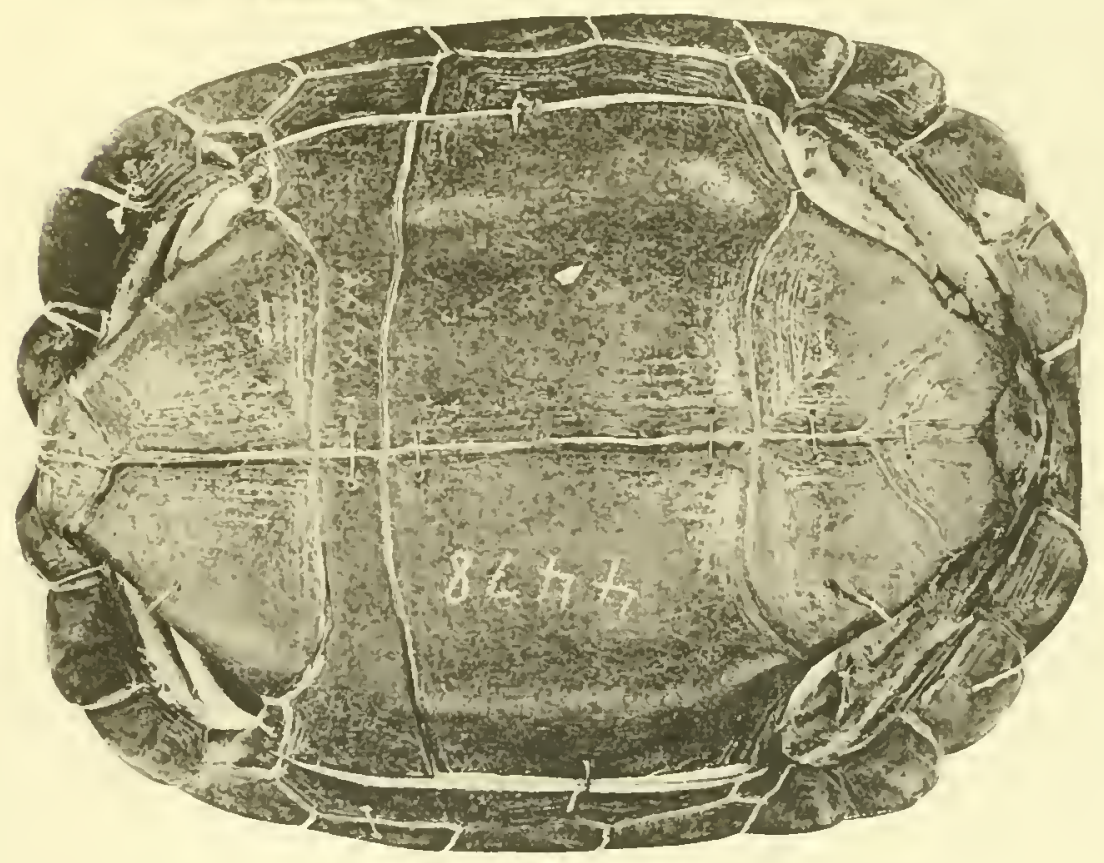



PLATE 27 


\section{PLATE 27.}

Testudo Nigra Quoy et Gaimard, 1824.

1 dorsal, 2 lateral, 3 ventral.

M. C. Z. 11074. Boston Society of Natural History. Length $24 \frac{3}{4}$ inches. 


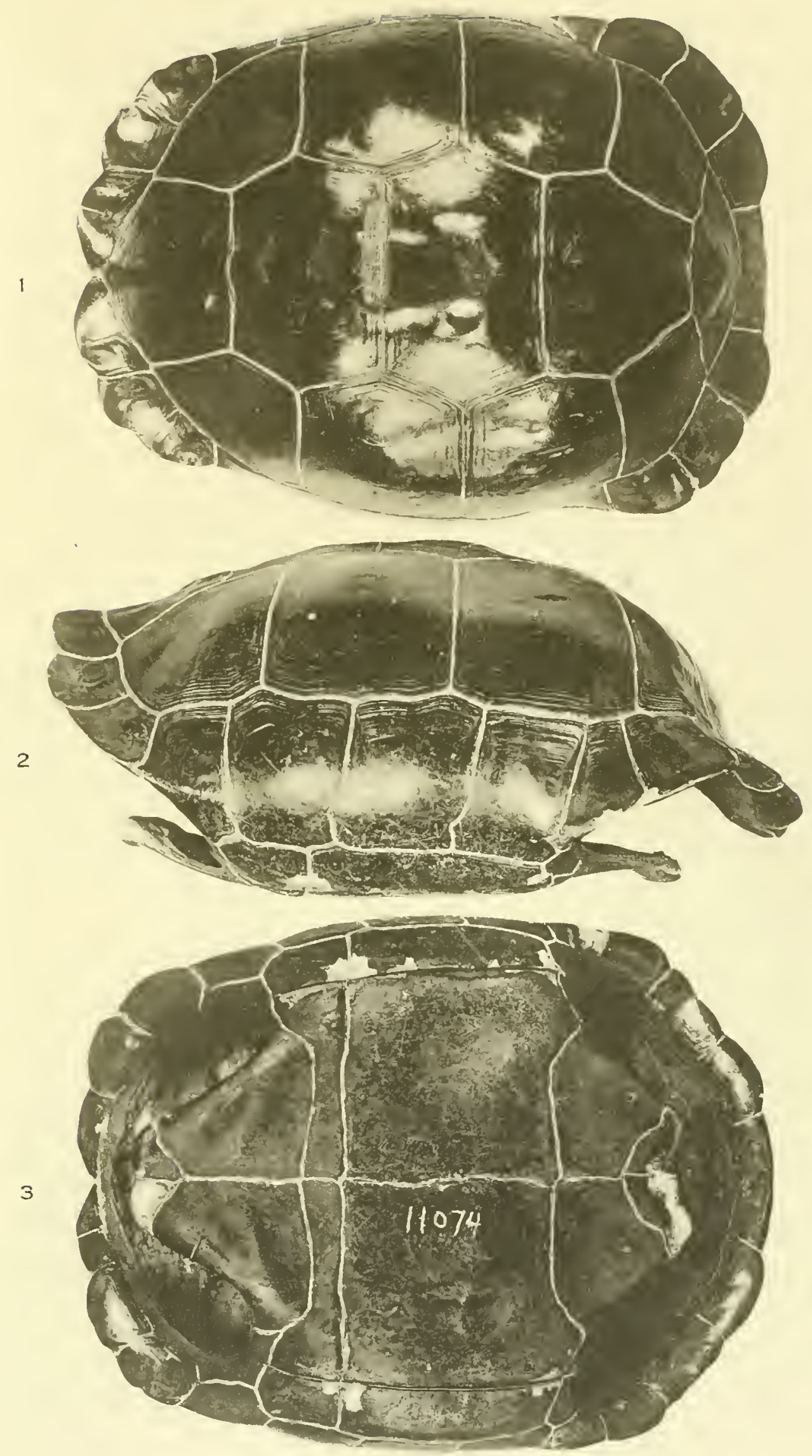



PLATE 28. 


\section{PLATE 28}

Testudo nigra Quoy et Gaimard, 1824.

Page 256

1 f lateral, $2 \sigma^{7}$ ventral, $3 \sigma^{7}$ lateral.

1 from Jackson, 1837, Boston Journ. Nat. Hist., 1, Plate 10. (T. elephantopne Jackson nec Harlan). MI. C. Z. 11069 \& Santa Maria (Charles). Boston Society of Natural History. Length 4212 inches.

2, 3 from Jackson, 1837, Boston Journ. Nat. Hist., 1, P'late 11 (T. elephantopus Jackson nec Harlan). 11. C. Z. 11070 o?. Santa Maria (Clarles). Boston Society of Natural Ilistory. Length $3 \$ \frac{1}{4}$ inches. 

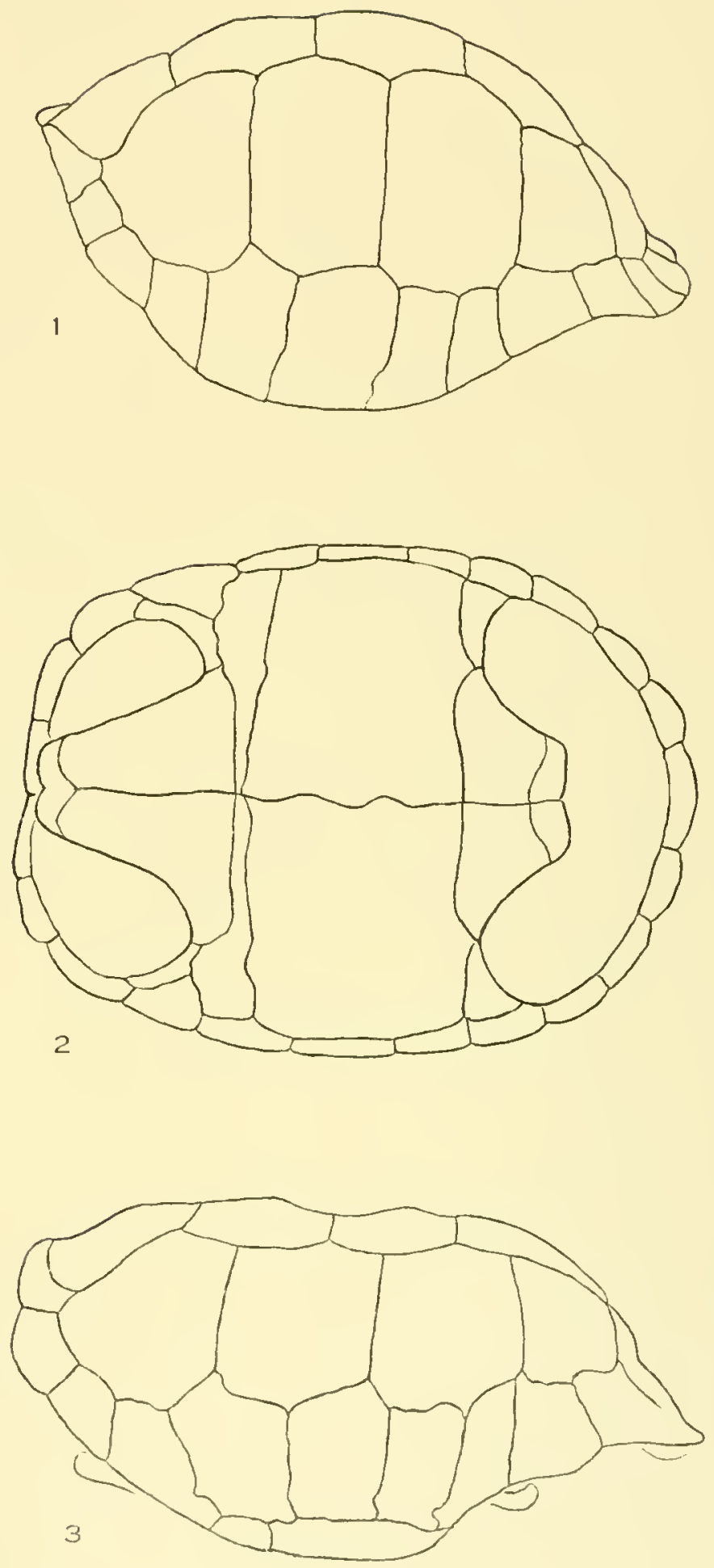

PLATE 29. 
PLATE 29.

Testudo nigra Quoy et Gaimard, 1824.

1 dorsal, 2 lateral, 3 ventral.

M. C. Z. 11070 O7. Santa Maria (Charles). Boston Society of Natural History. Length $38 \frac{1}{4}$ inches. 


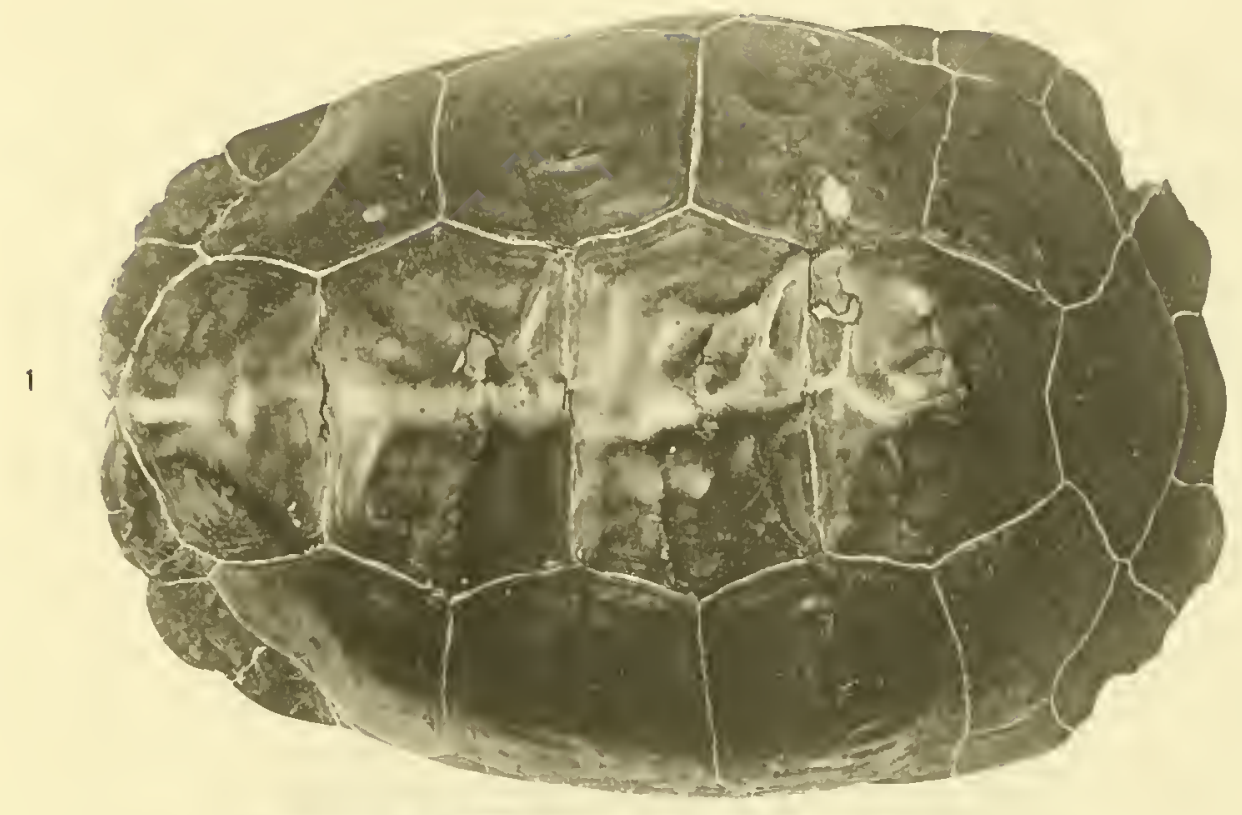

2

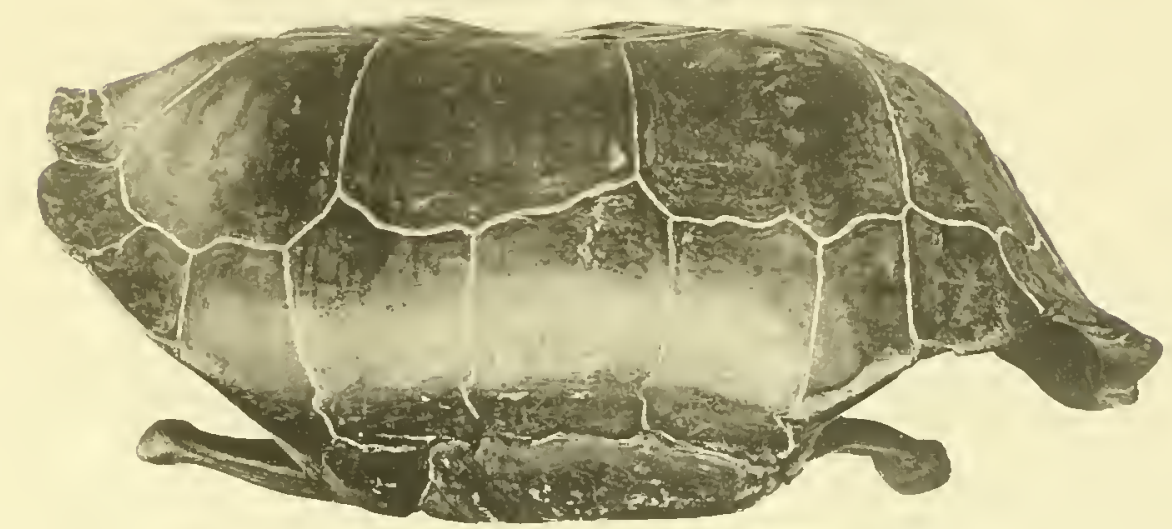

3

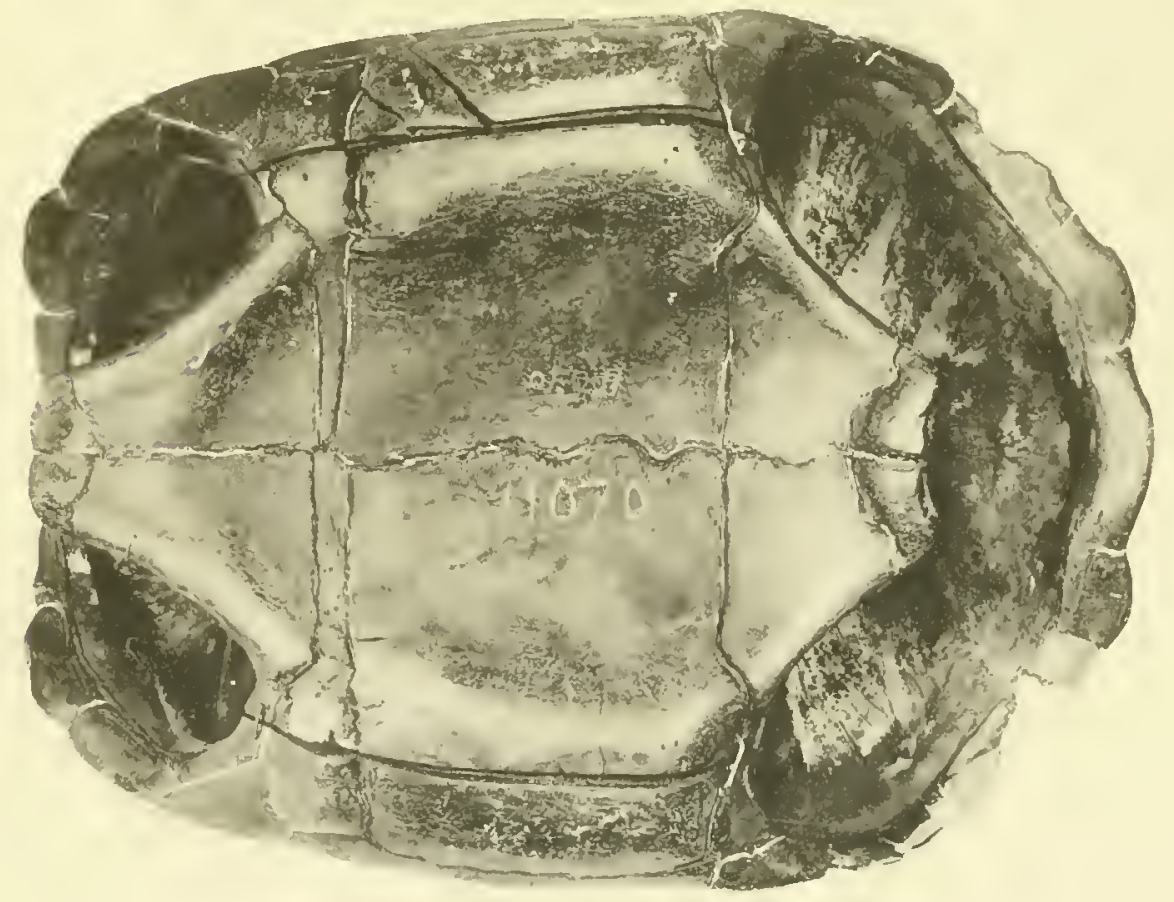



PLATE 30 


\section{PLATE 30}

Testedo nigra Quoy et Gaimard, 1824.

Page 286

1 dorsal, 2 ventral, 3 lateral.

From Ciüntlier, 1902, Nov. Zool, 9, Plate 16, 17 (T. galapagoensis Baur).

M. C. Z. 11070 ơ. Santa Maria (Charles). Boston Society of Natural History. Length $38_{4}^{1}$ inclies. 

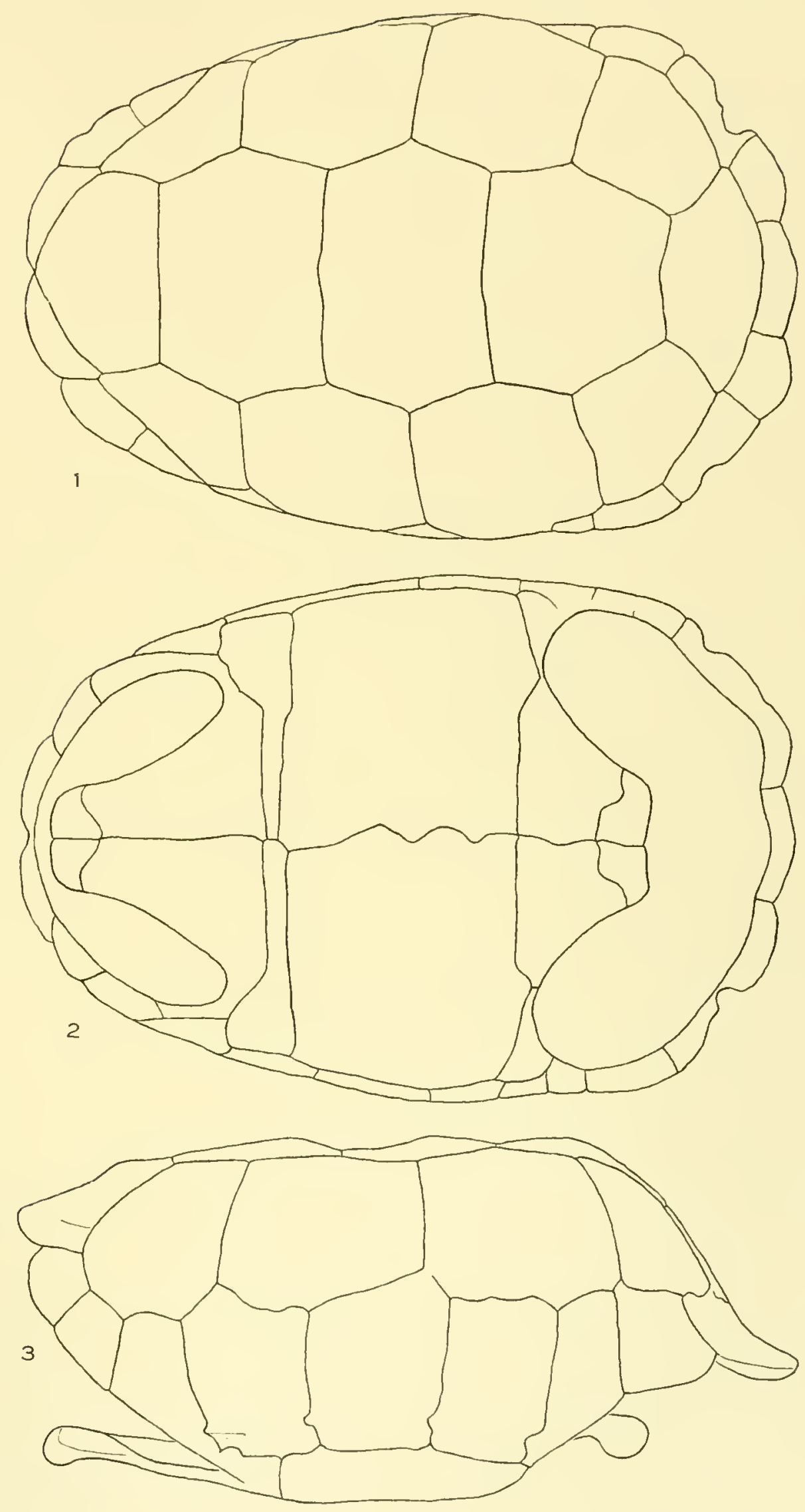

PLATE 31. 
PLATE 31.

Testudo nigra Quoy et Gaimard, 1824.

Page 286

1 dorsal, 2 lateral, 3 ventral.

M. C. Z. 11069 ․ Santa Maria (Charles). Boston Society of Natural History. Length $42 \frac{1}{2}$ inches. 

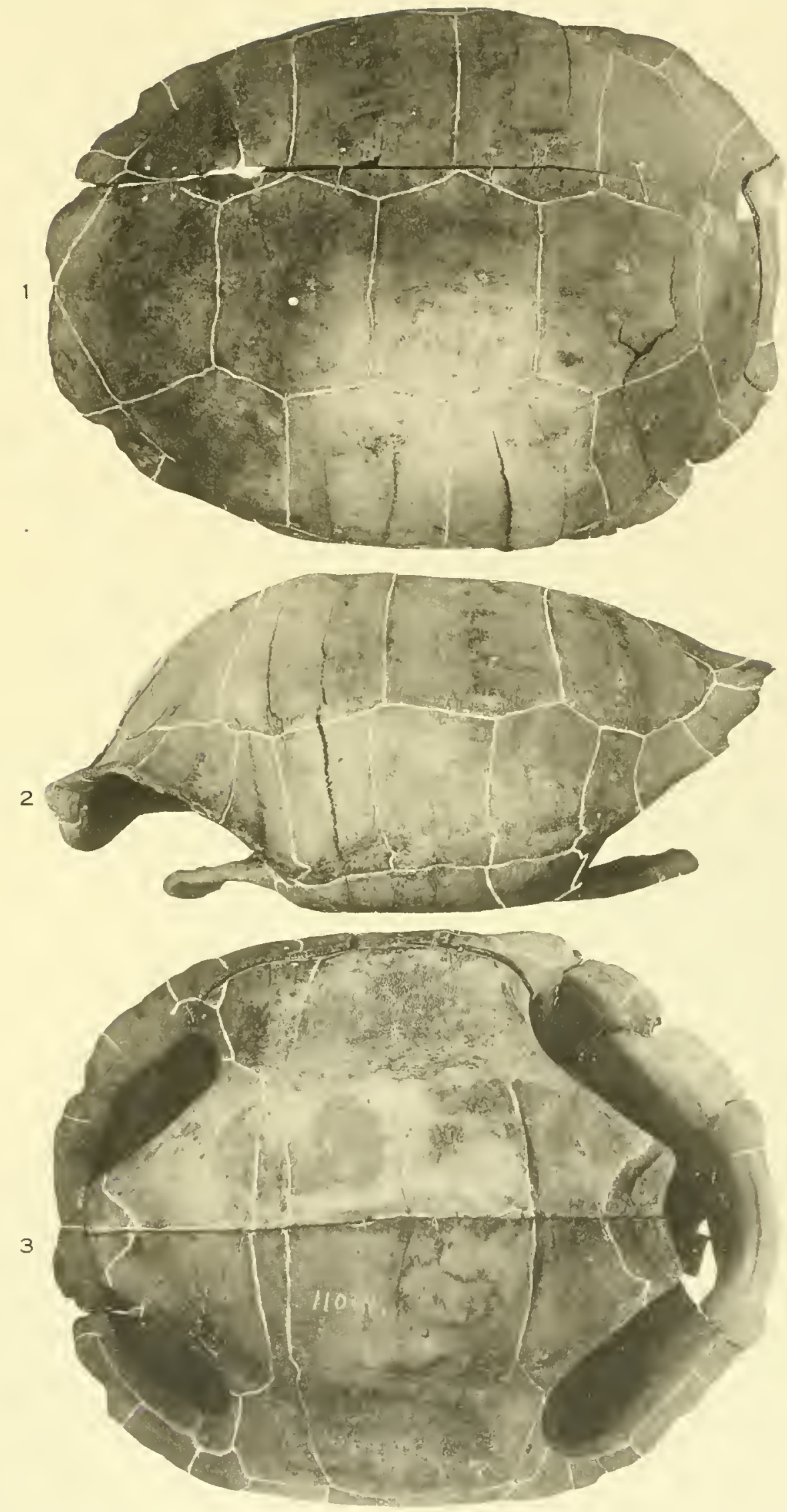

PLATE 32. 
PLATE 32.

Testudo Nigra Quoy et Gaimard, 1824.

Page 286

1 dorsal, 2 lateral, 3 ventral.

1, M. C. Z. 1905 \%. Santa Maria (Charles). Hassler Exped. Length $27 \frac{1}{2}$ inches.

2, 3 from Günther, 1902, Nov, Zool., 9, Plate 17, fig. B (T. galapagoensis Baur). 

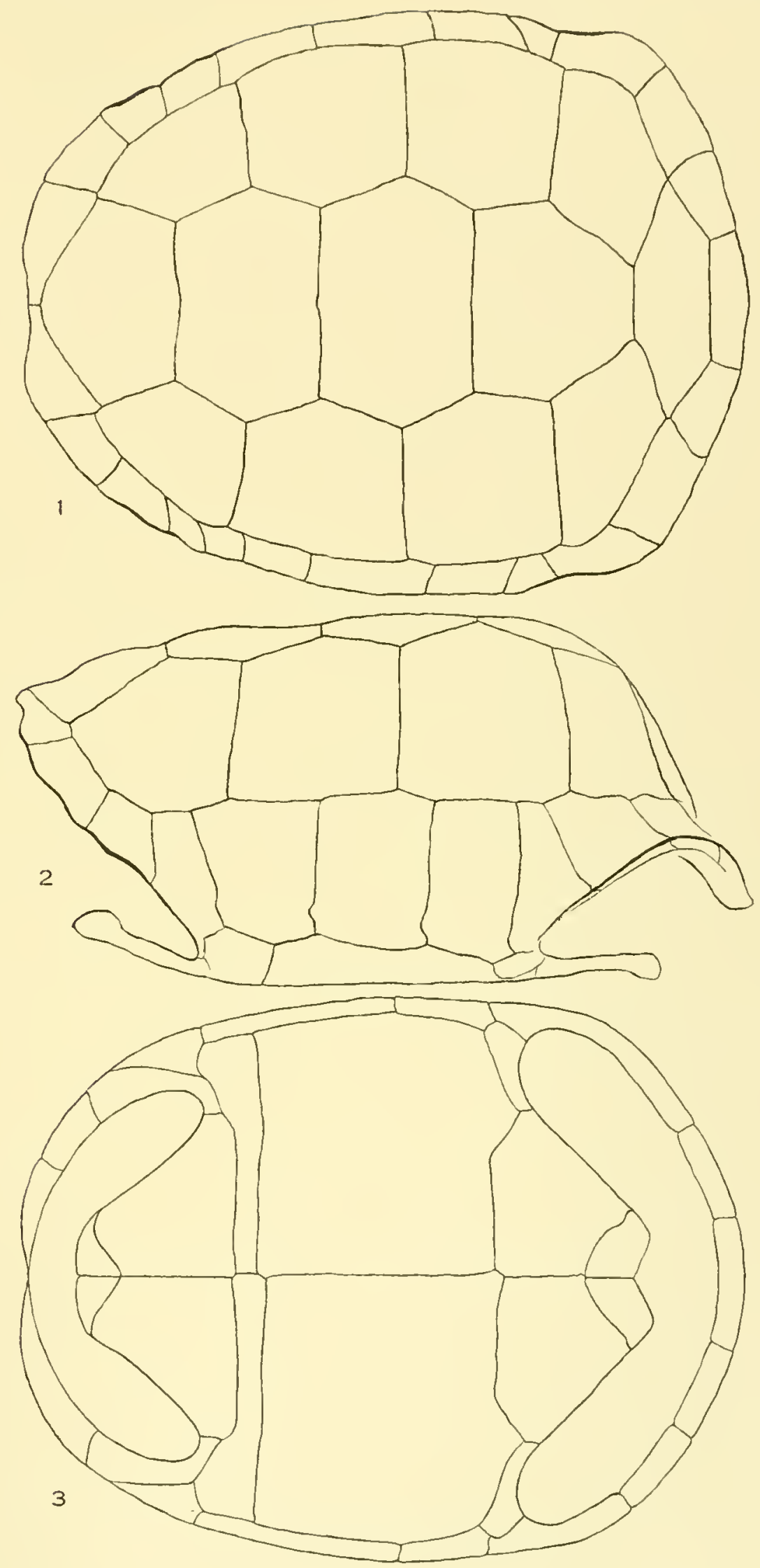

PLATE 33. 
PLATE 33

Testedo Nigra Quoy et Gaimard, 1824

1 dorsal, 2 lateral, 3 ventral.

M. C. \%. 1904 \&. Length $27 \frac{1}{2}$ inches. 

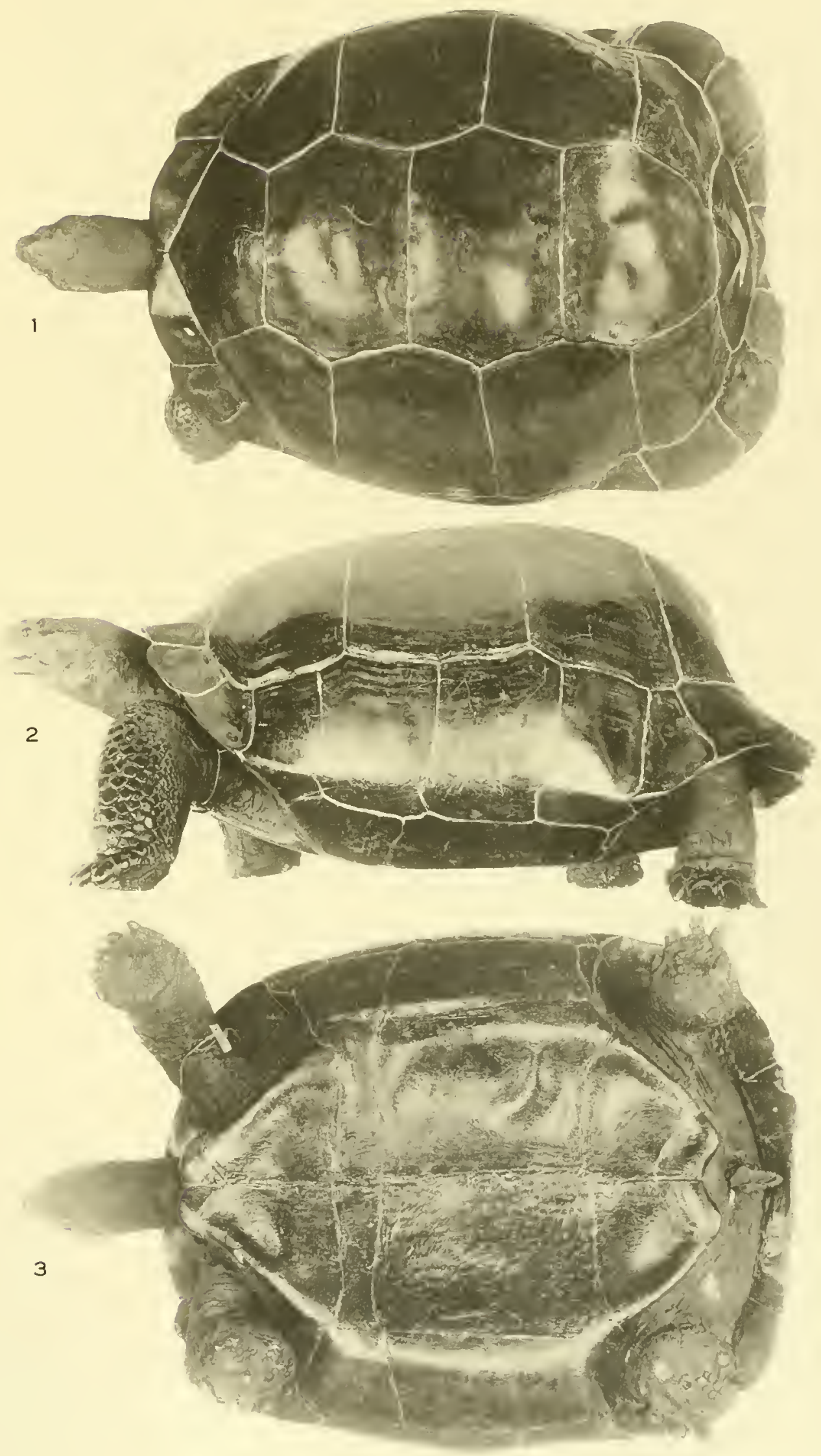

PLATE 34. 
PLATE 34

Testudo typica Garman, 1917.

Page 285

1 ventral, 2 dorsal, 3 lateral.

M. C. Z. 5260. H. A. Ward Coll. Length $28 \frac{1}{2}$ inches. 
MEM. MUS. COMP. ZOOL.

GALAPAGOS TORTOISES PLATE 34
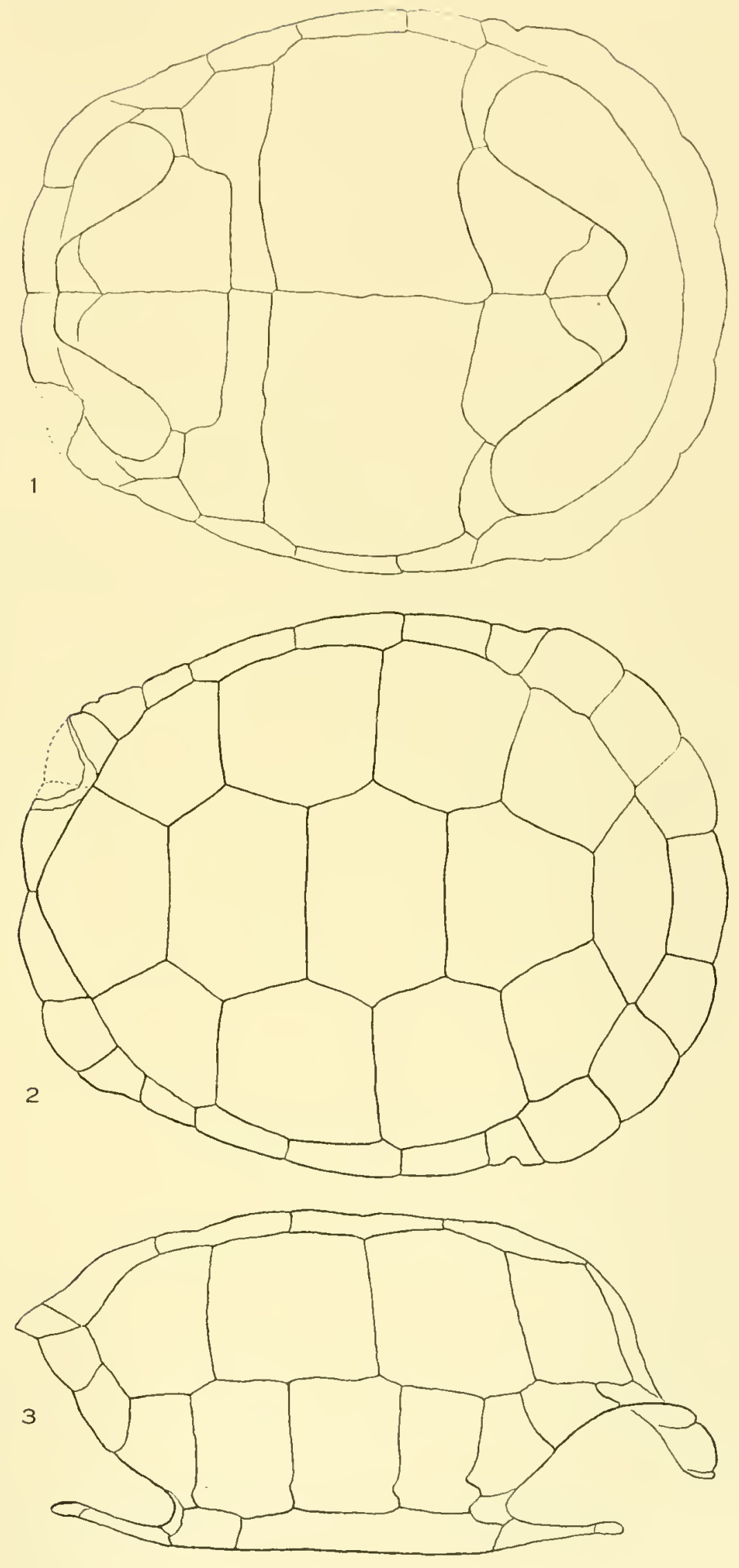

HELIOTYPE CO., BOSTON. 

PIATE 36. 
PIATE 35.

TEstTdo Nirra Quoy et Gaimard, 1824.

Page 286

1 dorsal, 2 lateral, 3 ventral

M. C. 'L. 11064. Boston Society of Natural History. Length $11 \frac{1}{4}$ inches, straight, of anowedenth, $53 \%$ can. 

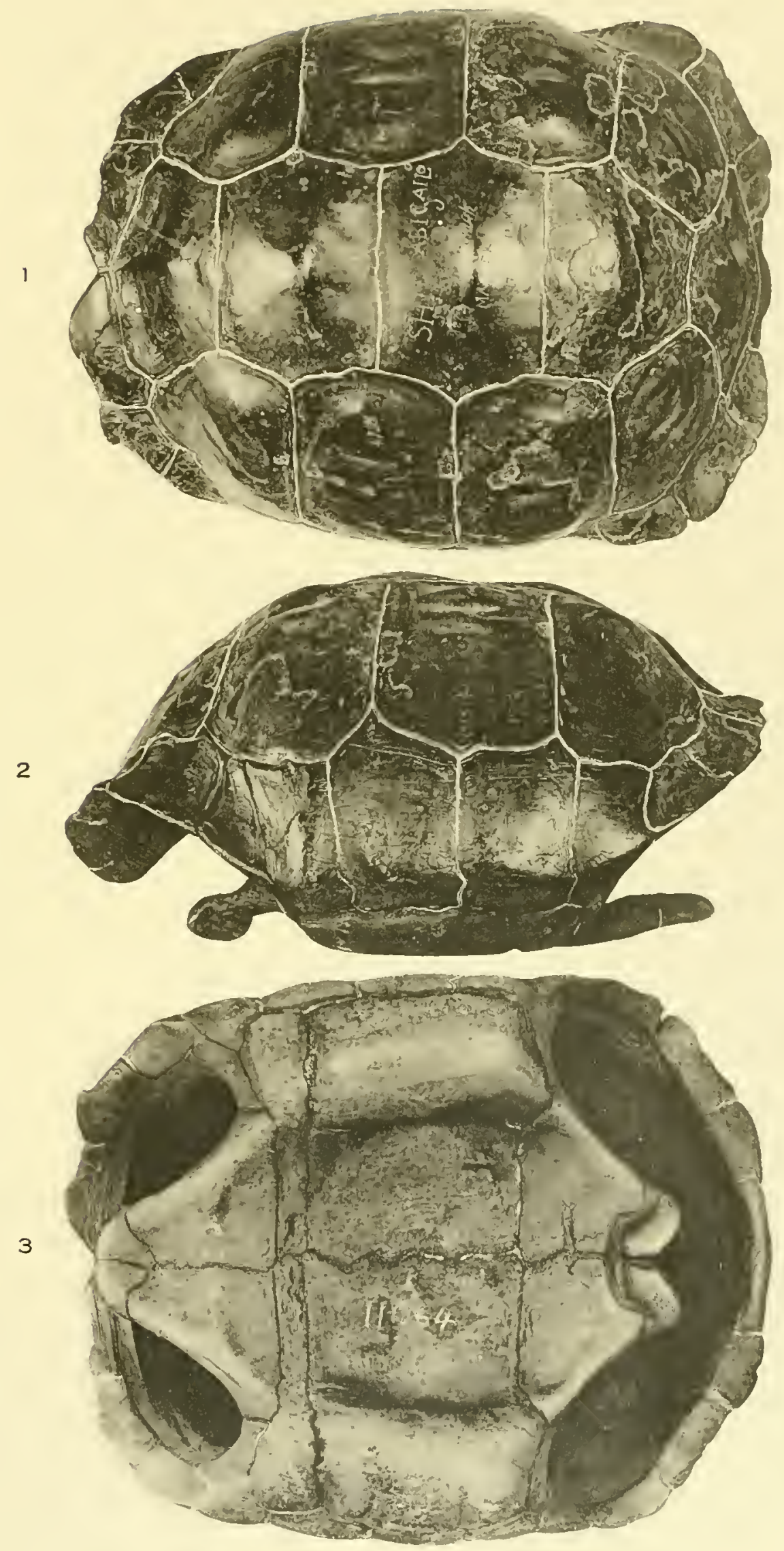

PLATE 36. 
PLATE 36.

Testudo Nigra Quoy et Gaimard, 1824.

1 dorsal, 2 lateral, 3 ventral.

M. C. Z. 4608. Charles Island. Ilassler Exped. Length 26 inches. 

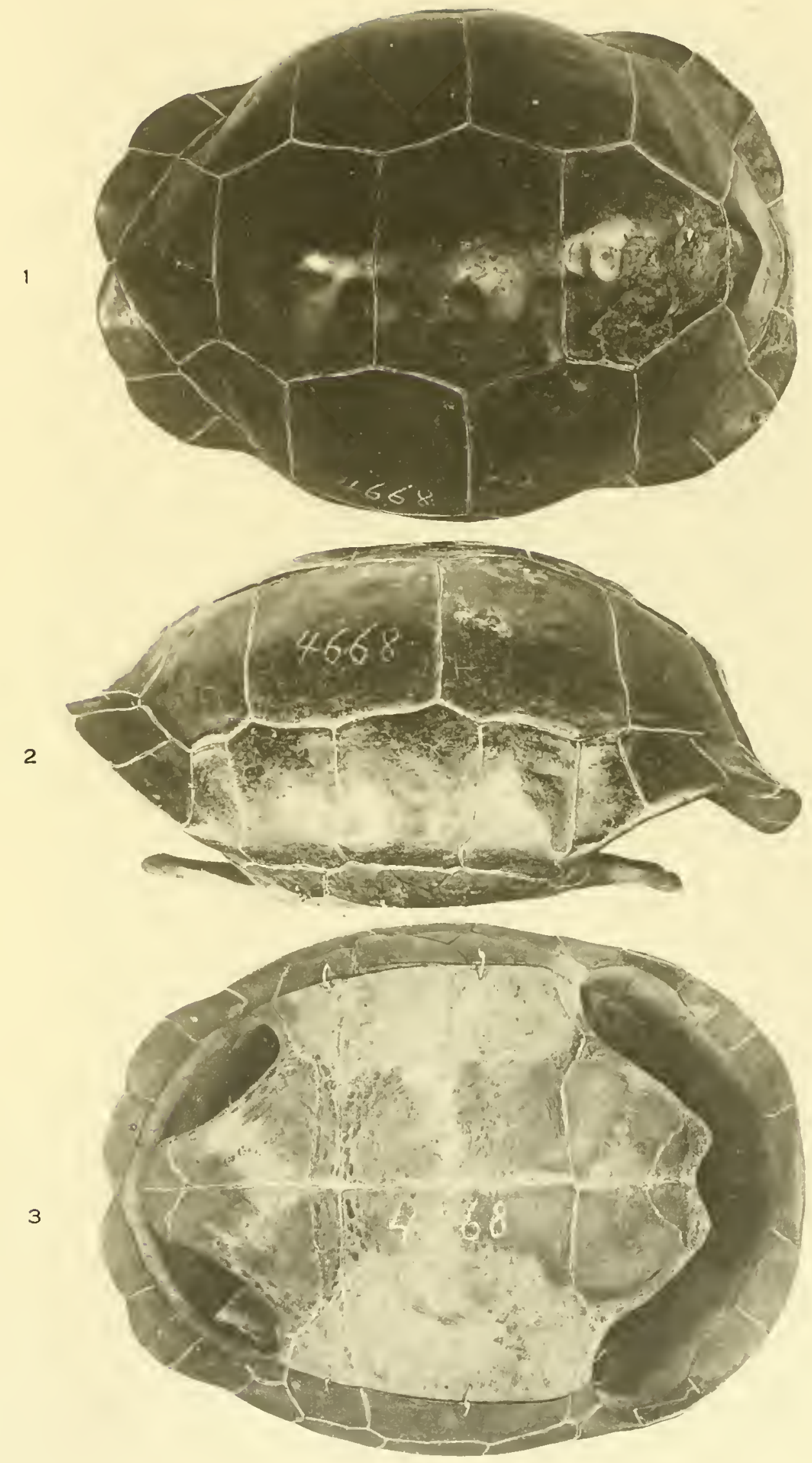

PLATE 37. 
PLATE 37.

Testudo elephavtopus Harlan, 1827.

Page 290

1, 3 lateral, 2 ventral.

1 M. C. Z. 11063. Boston Society of Natural History. Length $16 \frac{1}{4}$ inches.

2, 3 from Harlan, 1827, Journ. Acad. Nat. Sei. Philadelphia, 5, Plate 11. Med. and Phys. Researches. 1835, p. 190. 
MEM. MUS, COMP. ZOÖL.

GALAPAGOS TORTOISES PLATE 37
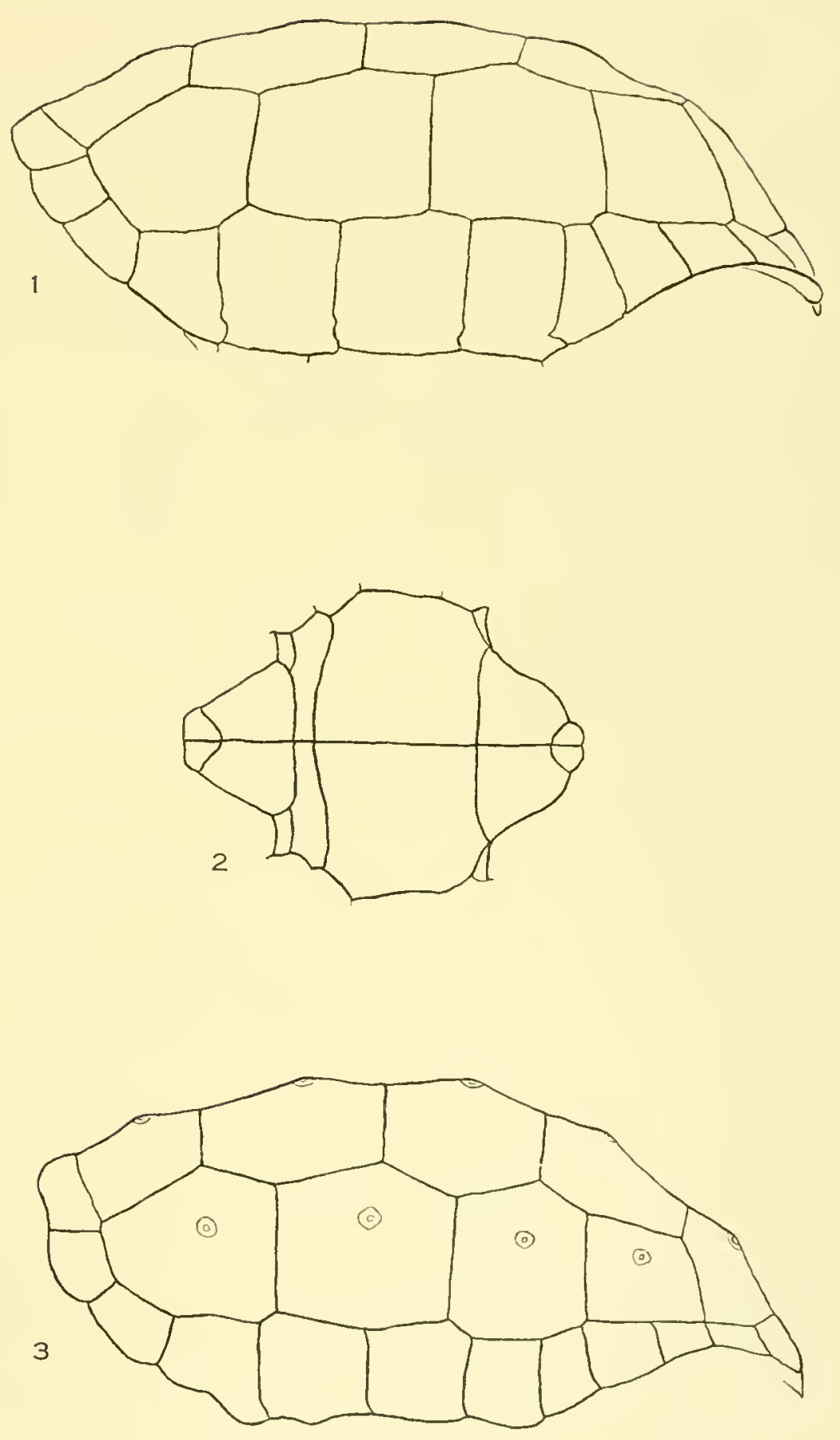

5.4

HELIOTYPE CO., BOSTON. 

PLATE 38. 
PLATE 38.

Testudo elephantopd Harlan 1827.

Page 290

1 dorsal, 2 lateral, 3 ventral.

1, 2 11. C. Z. 11063. Boston Society of Natural History. Length $16 \frac{1}{4}$ inches.

Testudo Microphyes Günther, 1875.

Page 280

3 M. C. Z. 11073. Boston Society of Natural History. Length 12 inches. 


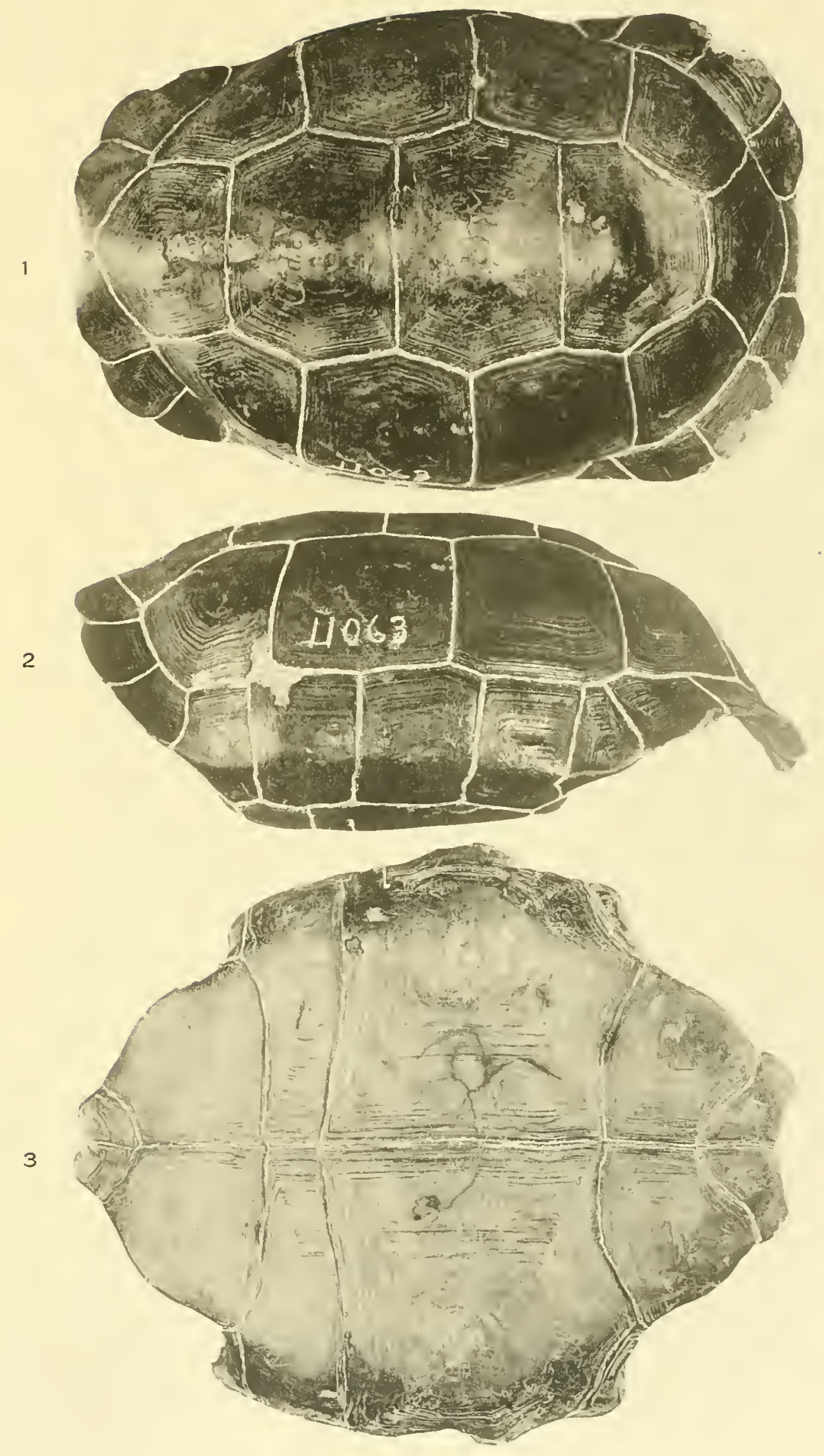



PLATE 39. 


\section{PLATE 39.}

Testudo elephantopus Frarlan, 1827.

Page 290

1 ventral, 2 dorsal, 3 lateral.

From Günther, 1875, Philos. Trans. Royal Soe. London, 165, Plate 34, 35, fig. B (T. ephippium (rünther).

Mus. Science and Arts Edinburgh. क TrPe ( $T$. ephippium Günther). Pinta (Abingdon)? Length 33 inches. 

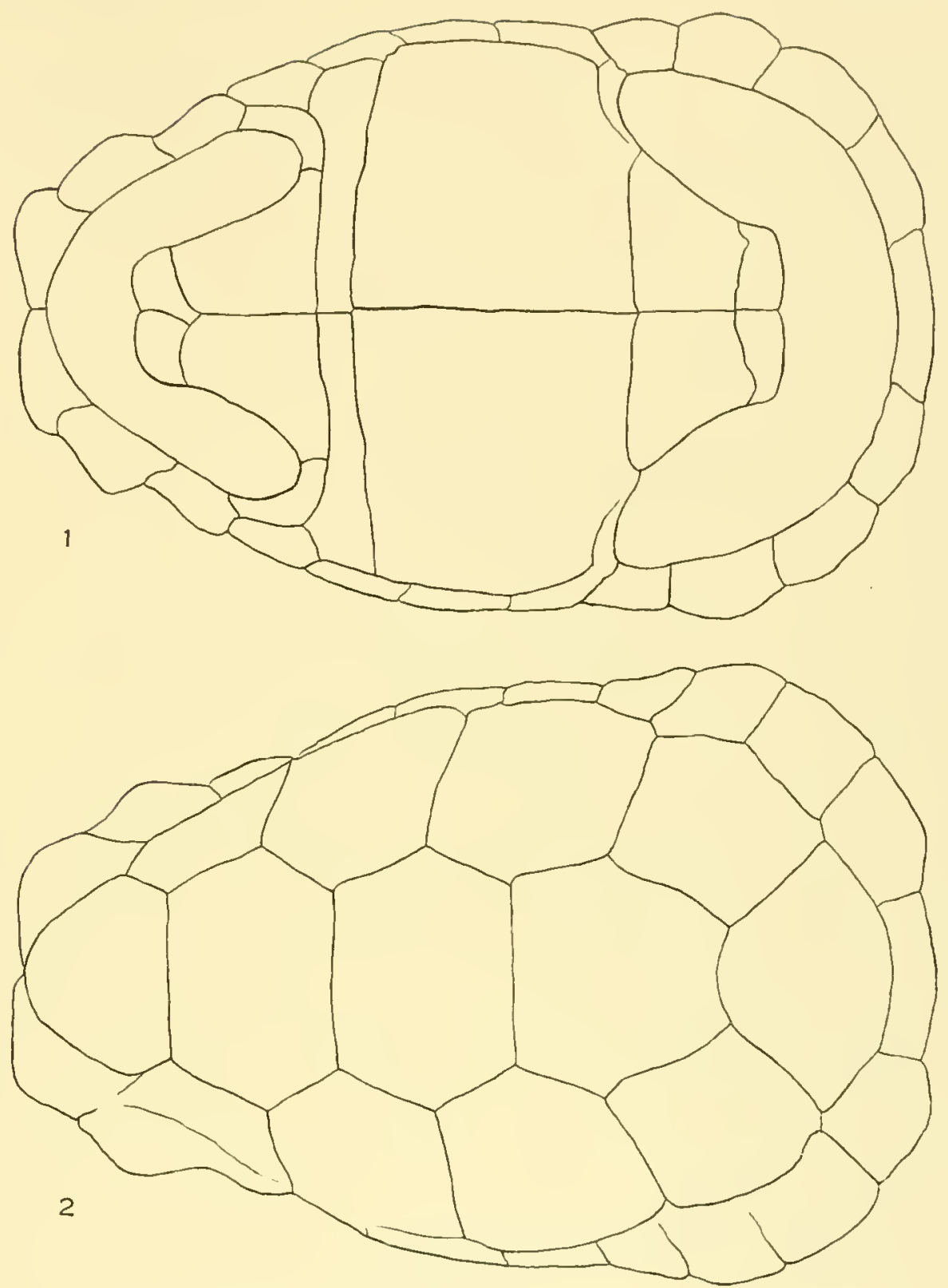

S.

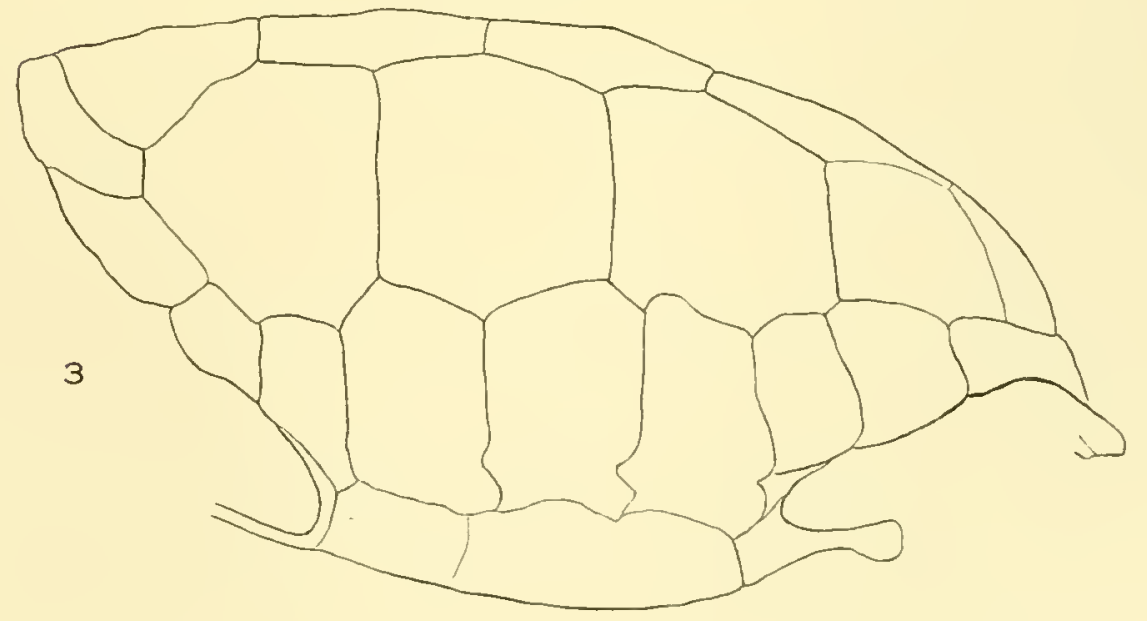



PLATE 40 
PLATE 40

Testedo elephantopus Harlan, 1827.

Page 290

1 ventral, 2 dorsal, 3 lateral.

From Günther, 1877, Gigantio tortoises, Plate 40, 41 (T. abingdoni Günther).

British Museum TrPe. (T', abingdoni Günther). Length 38 inches. 

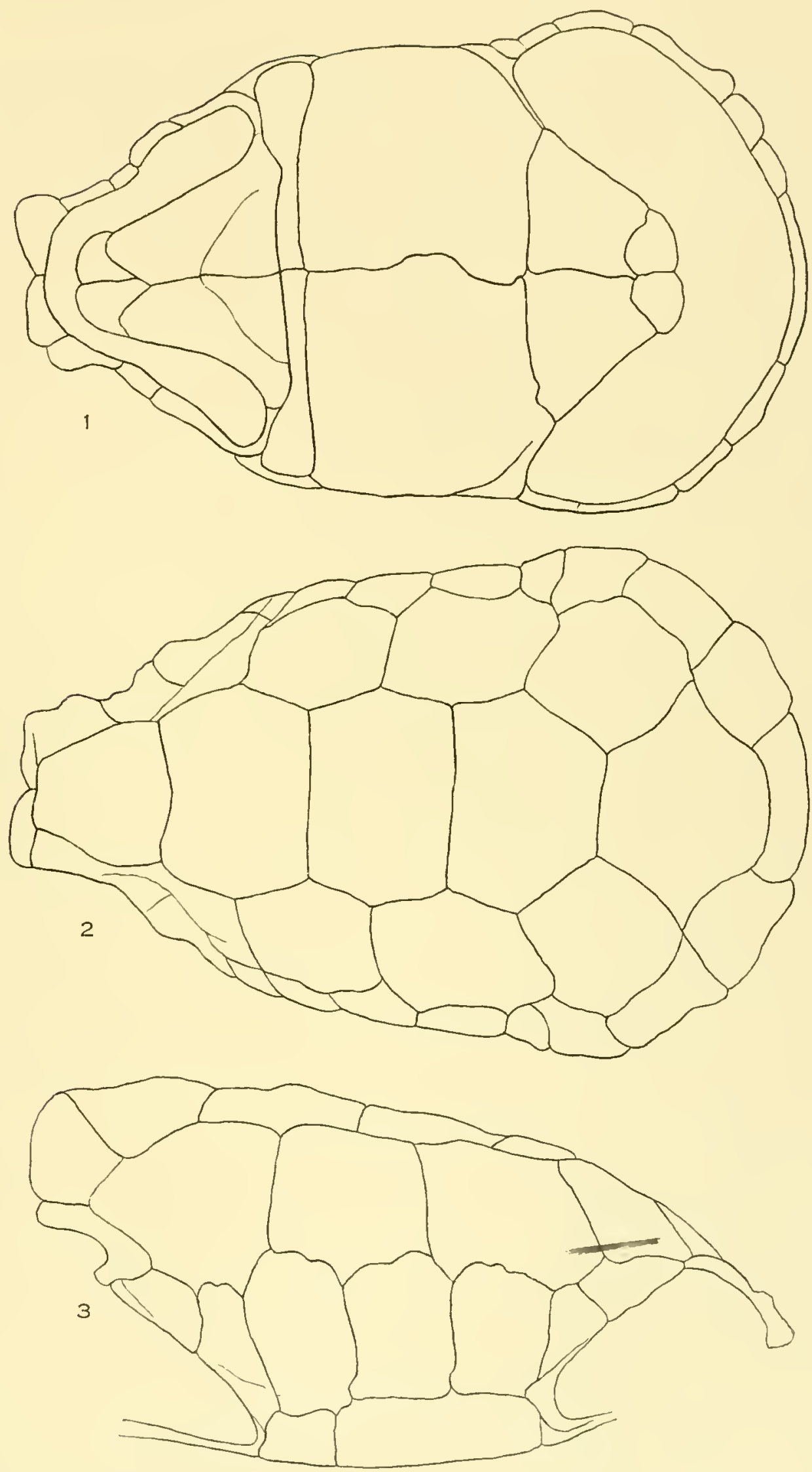

PLATE 41 
PIATE 41.

Testudo elephantopus Harlan, 1827.

1 dorsal, 2 lateral, 3 ventral.

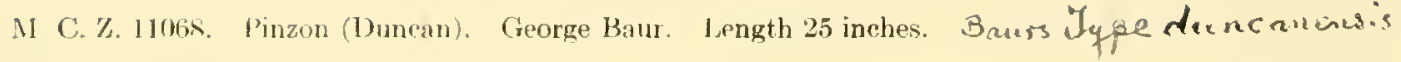




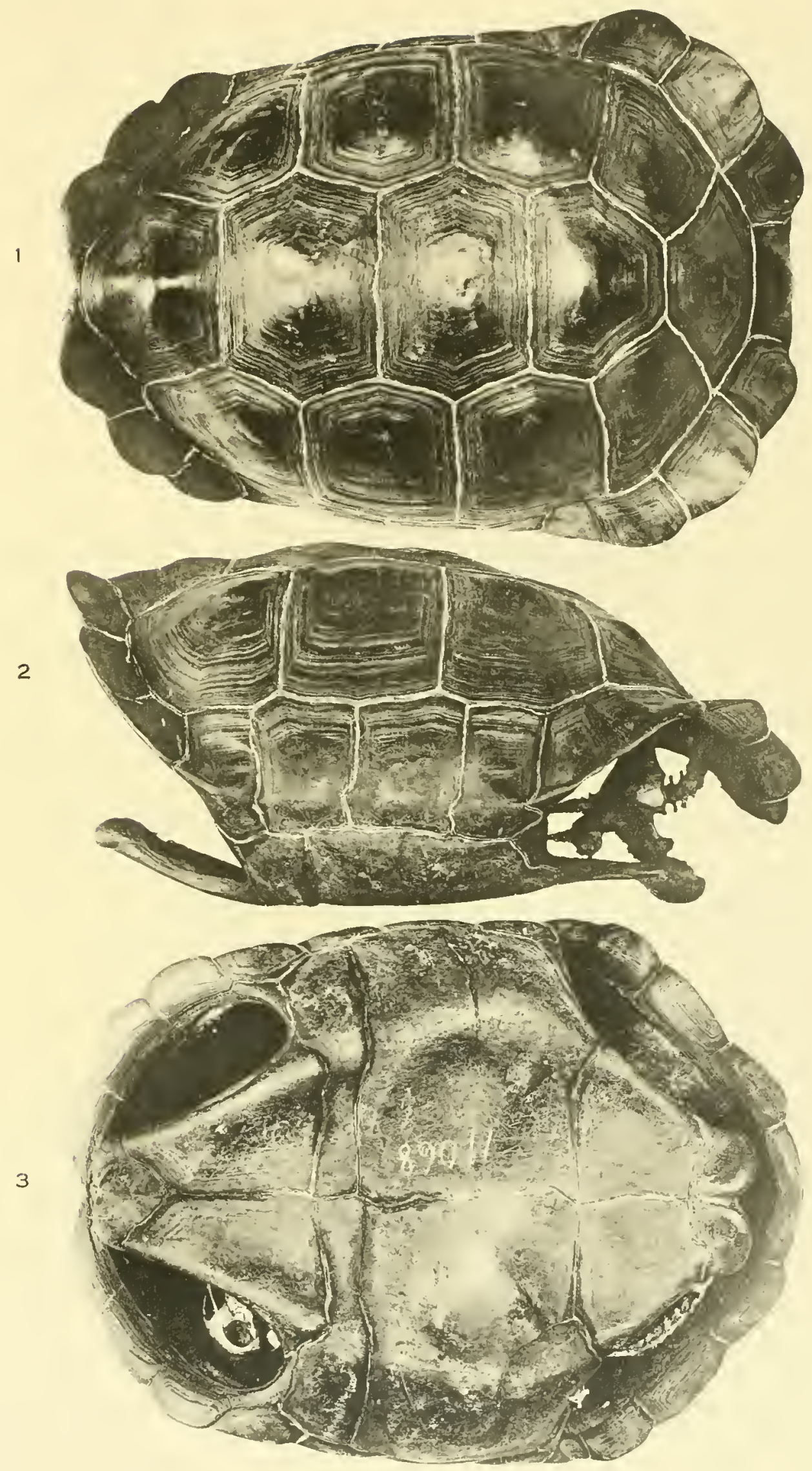




I'ATF, 42.

TESTUDO ELPPHANTOPTS Harlan. 1827.

Page 2!)1

1, 2 dorsal, 3 lateral.

1 M. C. Z. 11084 . CAST (T. becki Rothschild). F. B. Webster. Length, 16 inches. 2, 3 M. C. Z. 110 S3. Cast. IF. H. Wehster. Length $21 \frac{1}{2}$ inches. 


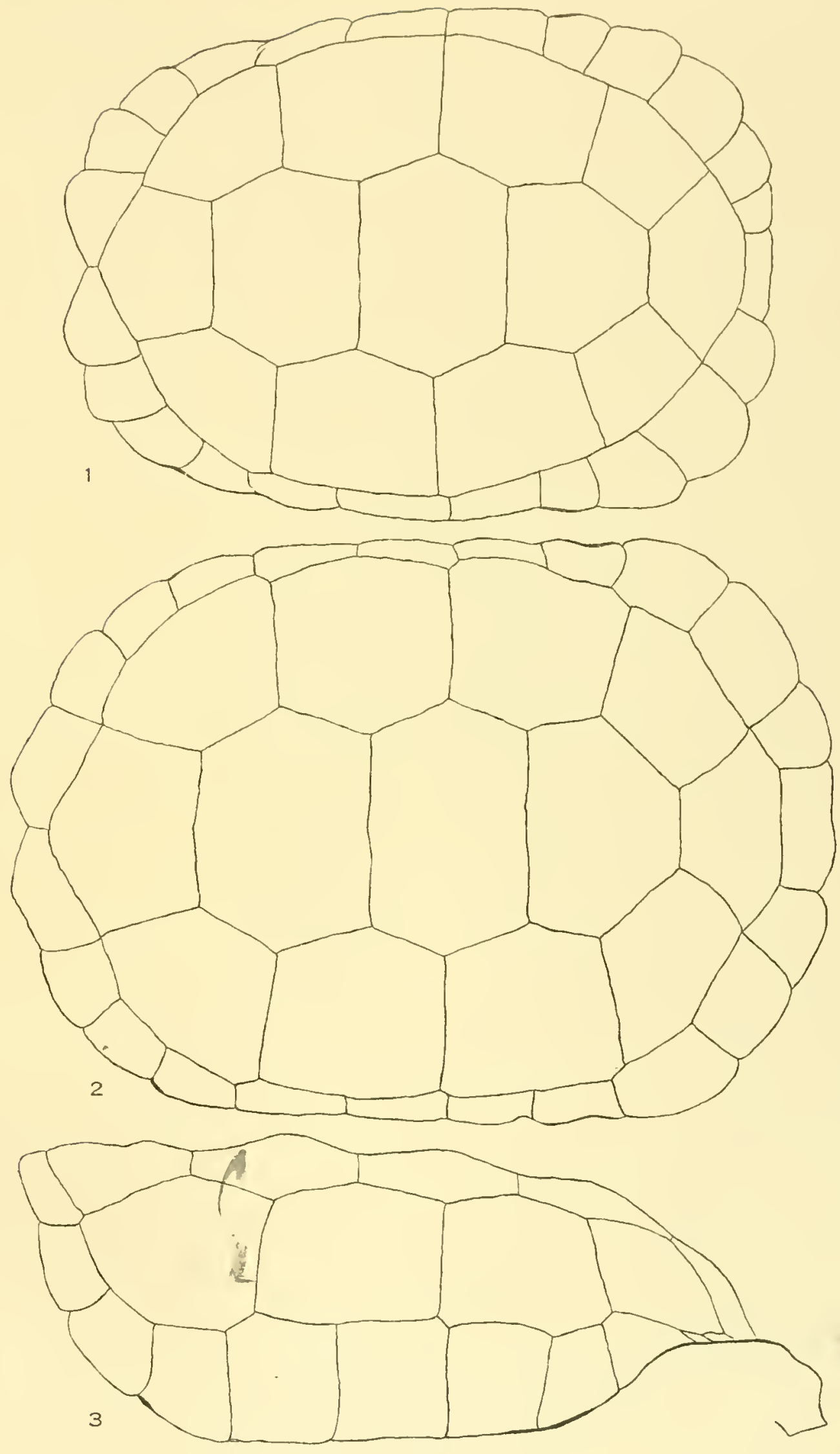









